\title{
Modelo para avaliação do efeito do déficit e do excesso hídrico sobre o rendimento do milho na localidade de Urussanga, Santa Catarina.
}

Antônio Sérgio Soares

Engenheiro Agrônomo

Orientador Prof. Doutor Tarlei Arriel Botrel

Dissertação apresentada à Escola Superior de Agricultura "Luiz de Queiroz", da Universidade de São Paulo, para obtenção do título de Mestre em Agronomia, Área de Concentração: Irrigação e Drenagem.

PIRACICABA

Estado de São Paulo - Brasil

Agosto - 1996 
Dados Internacionais de Catalogação na Publicação (CIP)

DIVISÃO DE BIBLIOTECA E DOCUMENTAÇÃO - Campus "Luiz de Queiroz"/USP

Soares, Antônio Sérgio

Modelo para avaliação do efeito do déficit e do excesso hidrico sobre

o rendimento do milho na localidade de Urussanga, Santa Catarina / Antônio Sérgio Soares. - - Piracicaba, 1996.

88p. : il.

Dissertação (mestrado) - - Escola Superior de Agricultura Luiz de Queiroz, 1996.

Bibliografia.

1. Balanço hidrico 2. Déficit hidrico - Avaliação - Modelo 3. Milho - Irrigạ ção - Efeito 4. Milho - Rendimento - Urussanga, SC I. Titulo

CDD 633.15

631.7

551.48 
Modelo para avaliação do efeito do déficit e do excesso hídrico sobre o rendimento do milho na localidade de Urussanga, Santa Catarina.

Antônio Sérgio Soares

Aprovada em 27. 08. 1996

Comissão julgadora:

Prof. Dr. Tarlei Arriel Botrel ESALQ/USP

Prof. Dr. Valter Barbieri ESALQ/USP

Prof Dr. Hugo Ghelfi Filho ESALQ/USP

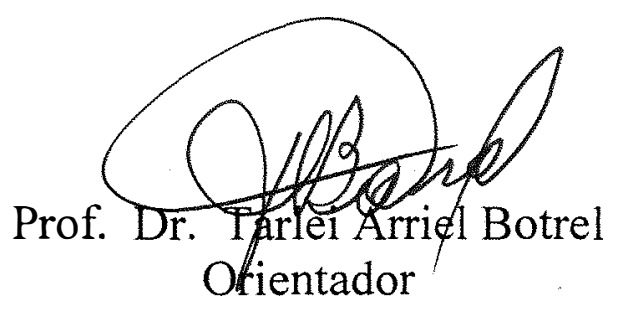


Para

Edna e Felipe, minha esposa e filho; Raul e Águida, meus pais;

Meus irmãos

Dedico 


\section{AGRADECIMENTOS}

Ao professor Tarlei Arriel Botrel pelos ensinamentos, amizade e orientação deste trabalho.

Aos pofessores do departamento de Engenharia Rural pelos ensinamentos transferidos durante a realização do curso e dedicação com que desenvolvem seus trabalhos.

Aos professores do departamento de Física e Meteorologia, pelo apoio e sugestões fornecidas.

Aos pesquisadores Euclides Mondardo, Darci Antônio Althoff e Álvaro José Bach pelo fornecimento dos dados sobre a cultura.

Aos funcionários da Gerência Estadual de Recursos Naturais da EPAGRI, pelo fornecimeto dos dados climáticos.

Aos colegas do curso pelo companheirismo.

Aos funcionários do Centro de Tecnologia Agrícola Sul Catarinense, especialmente os do Centro de Treianamento de Araranguá, pelo apoio demonstrado.

A Empresa de Pesquisa e Extensão Rural de Santa Catarina, EPAGRI pela oportunidade concedida.

A Coordenadoria de Aperfeiçoamento de Pessoal de Ensino Superior CAPES, pelo suporte financeiro. oferecido.

A Escola Superior de Agricultura Luiz de Queiroz - ESALQ, pelo curso 


\section{SUMÁRIO}

1. INTRODUÇÃO

2. REVISÃO DE LITERATURA 4

2.1. O efeito do déficit hídrico sobre o rendimento das culturas 4

2.2. O efeito do excesso hídrico sobre o rendimento das culturas 8

2.3. O efeto da irrigação sobre o rendimento das culturas 14

$\begin{array}{ll}\text { 2.4. Modelos de simulação do rendimento } & 18\end{array}$

3. MATERIAL E MÉTODOS 30

3.1. Origem dos dados $\quad 30$

3.2. Cracterização do local dos experimentos $\quad 30$

$\begin{array}{ll}3.2 .1 \text {. Clima } & 30\end{array}$

3.2.2. Solos $\quad 30$

3.3. Dados experimentais $\quad 32$

3.3.1. Metodologia dos experimentos $\quad 32$

3.3.2. Variedades utilizadas 33

3.4 Rendimento potencial 35

3.3.3. Informações fenológicas e de rendimento 34

3.5. Dados meteorológicos $\quad 39$

3.6. Balanço hídrico 39

3.6.1. Cálculo da evapotranspiração através do método de Penman $\quad 40$

3.6.2. Equação para cálculo de evapotrasnspiração no período que não se dispõe de todos os dados para a aequação dePenman $\quad 42$

3.6.3. Cálculo da evapotranspiração máxima da cultura (Etm) 44 
3.6.4. Cálculo da evapotranspiração real (Eta) 46

3.6.5. Cálculo do excesso e do déficit de água no solo 48

3.6.6. Aferição do balanço hídrico 51

3.7. Equação para estimativa do rendimento de grãos 51

3.8. Análise estatística 52

3.9. Determinação dos rendintos reais no período anterior à série de dados 53

3.10. Determinação do efeito da irrigação (ou do déficit) 53

3.11 Determinação do efeito do excesso hídrico 54

3.12. Estudo de probabilidade de ocorrência de acréscimos de rendimento 54

4. RESULTADOS E DISCUSSÃO 56

4.1. Balanço hídrico 56

4.2. Modelos de simulação dos rendimentos $\quad 59$

4.2.1. Modelo com déficit de água no solo 59

4.2.2. Modelo com excesso de água no solo 63

4.2.3. Modelo completo $\quad 66$

4.2.3.1. Validação do modelo completo $\quad 69$

4.4. O efeito da irrigação sobre os rendimentos $\quad 71$

4.5. O efeito do excesso hídrico sobre os rendimentos 73

4.6. Tempo de retorno dos ganhos com a irrigaçào simulada 77

5. CONCLUSÕES $\quad 80$

6. REFERÊNCIAS BIBLIOGRÁFICAS 81 


\section{LISTA DE FIGURAS}

Página

Figura 1 - Indice diário de excesso (FEX) em função do número dias consecutivos sob excesso hídrico, para o periodos plantioflorescimento masculino (P -F) e florescimento-maturação fisiológica (F - MF).

Figura 2 - Rendimento observado e calculado com a equação obtida com índice de déficit 1-ETa/ETm (D) e FEX (E), para variedades de ciclo normal.

Figura 3 - Rendimento observado e calculado com a equação obtida com o índice de déficit 1-ETa/ETm (D) e de excesso FEX (E), para as variedade de ciclo precoce.

Figura 4 Rendimento observado e calculado com a equação completa, 1ETa/ETm e FEX nas 6 fases fenológicas da cultura para as variedades de ciclo normal (N) e precoces (P), no período 1975- 1994.

Figura 5 - Rendimento observado (OBS)e calculado através de validação cruzada (CALC) no período de 1975 - 1994 para variedades de ciclo normal $(\mathrm{N})$ e precoce $(\mathrm{P})$.

Figura 06 - Rendimento com déficit e excesso (1), rendimento sem o efeito do déficit (2), rendimento sem o efeito do excesso e do déficit (3), para variedades de ciclo normal $(\mathrm{N})$ e precoce $(\mathrm{P})$.

Figura 07 - Ganhos com irrigação simulados com o modelo completo e tempos de retorno com distribuição empírica (EMP), Gama (GAMA) e modelo exponencial (EXP), para variedades de ciclo normal $(\mathrm{N})$ e precoce $(\mathrm{P})$. 


\section{LISTA DE QUADROS}

Página

Quadro 1 - Percentagem de argila, silte e areia, densidade global, umidade em $\%$ peso para tensões de 1/3 e 15 atmosferas do solo Morro da Fumaça. 31

Quadro 2 - Percentagem de argila, silte e areia, densidade global, umidade em \% peso para tensões de $1 / 3$ e 15 atmosferas do solo Içara.

Quadro 3 - Percentagem de argila, silte e areia, densidade global, umidade em \% peso para tensões de 1/3 e 15 atmosferas do solo Hidromórfico

Quadro 4 - Número de variedades de ciclo normal e precoce plantadas e recomendadas para os anos de 1975-1994.

Quadro 5 - Ano de semeadura, número de variedades, data de semeadura, rendimento médio (Ya), déficit de rendimento relativo médio $(-\mathrm{Ya} / \mathrm{Ym})$ das variedades de ciclo normal e precoce utilizadas neste trabalho..

Quadro 6- Variáveis utilizadas na equação para cálculo da ETo, Constante, Coeficientes $\mathrm{c} 1$ até $\mathrm{c} 6$, Teste $\mathrm{T}$ e nível de significância das variáveis. 43

Quadro 7- Análise de Variância dos coeficiente e da equação para estimativa da evapotranspiração no período sem dados para a equação de Penman. 44

Quadro 8 - Coeficientes culturais $(\mathrm{kc})$ para as diferentes fases fenológicas da cultura, nos anos de 1976-1977, 1977-1978, 1978-1979 e 1979-1980, e médias, obtidos por Matzenauer (1983).

Quadro 9 - Fases fenológicas da cultura e valores de coeficientes culturais $(\mathrm{kc})$, para variedades de ciclo tardio e precoce.

Quadro 10 - Fator de sensibilidade do milho para vários dias consecutivos de encharcamento do solo em diferentes fases fenológicas da cultura.

Quadro 11 - Freqüência de déficits (1-ETa/ETm) e excessos (FEX) no solo nas seis fases fenológicas da cultura para as variedades de ciclo normal e precoce, nos 28 anos do estudo, (1965-1994). 
Quadro12 - Índices de déficit 1-ETa/ETm e de excesso FEX em cada fase fenológica da cultura dos anos de 1965-1994, para as variedades e ciclo normal.

Quadro 13 - Índices de déficit 1-ETa/ETm e de excesso FEX em cada fase fenológica da cultura dos anos de 1965-1994, para as variedades de ciclo precoce.

Quadro 14 - Rendimento observado (Ya), calculado com o modelo com índice de déficit (1-ETa/ETm), de excesso (FEX), modelo completo (1ETa/ETm e FEX) e a validação (VALID) para variedades de ciclo normal.

Quadro 15 - Rendimento observado (Ya), calculado com o modelo com índice de déficit (1-ETa/ETm), de excesso (FEX), modelo completo (1$\mathrm{ETa} / \mathrm{ETm}$ e FEX) e a validação (VALID) para variedades de ciclo precoce.

Quadro 16 - Coeficientes, valor $\mathrm{F}$ da análise de variância, nível de significância, e coeficiente de correlação $\mathrm{R}^{2}$ obtidos no desenvolvimento das equações completa (1-ETa/ETm e FEX), com índice de déficit (1$\mathrm{ETa} / \mathrm{ETm}$ ) e índice de excesso (FEX), para variedades de ciclo normal e precoce.

Quadro 17 - Rendimento potencial (Ym), observado (Ya), calculado com o modelo completo (CALC), com irrigação simulada (IRR), ganho com a irrigação simulada (GANHO) e diminuição do rendimento devido ao efeito do excesso (EXCESSO), para as variedades de ciclo normal.

Quadro 18 - Rendimento potencial (Ym), observado (Ya), calculado com o modelo completo (CALC), com irrigação simulada (IRR), ganho com a irrigação simulada (GANHO) e diminuição do rendimento devido ao efeito do excesso (EXCESSO), para as variedades de ciclo precoce. 


\title{
MODELO PARA AVALIAÇÃO DO EFEITO DO DÉFICIT E DO EXCESSO HÍDRICO SOBRE O RENDIMENTO DA CULTURA DO MILHO NA LOCALIDADE DE URUSSANGA, SANTA CATARINA
}

\author{
Autor:ANTÔNIO SÉRGIO SOARES \\ Orientador: Prof. DR. TARLEI ARRIEL BOTREL
}

\section{RESUMO}

A irrigação tem sido um recurso tecnológico fundamental para que se atinjam bons rendimentos nas culturas, notadamente nas regiões secas. Nas regiões úmidas ou sub úmidas, apesar da ocorrência de precipitações em quantidade suficiente, muitas vezes elas ocorrem com distribuição temporal inadequada. Tal distribuição faz com que o solo apresente períodos de déficit e de excesso de água, ambos prejudiciais ao bom desenvolvimento, causando instabilidade no desempenho das culturas. A incerteza quanto à ocorrência desses fenômenos, impede que agricultores invistam em projetos de irrigação. Com o objetivo de amenizar tal problema, este trabalho estuda os efeito do déficit e excesso hídrico sobre o rendimento da cultura do milho, na localidade de Urussanga, Santa Catarina.

Utilizou-se, neste trabalho, uma série de dados de produção e de fenologia da cultura do milho, de ciclo normal e precoce, e de dados climáticos diários de 28 anos, ambos coletados na Estação Experimental de Urussanga, Região Sul de Santa Catarina. Utilizaram-se, também informações de características físico hídricas dos solos destes experimentos. Com os dados climáticos, de fenologia da cultura e de solo, efetuou-se o balanço hídrico, extraindo-se deste as variáveis hídricas, que correlacionadas aos dados de rendimento da cultura, para ajuste de modelo de produção. Para o desenvolvimento do modelo utilizaram-se regressões múltiplas entre o déficit de rendimento relativo da cultura (1-Ya/Ym) e as variáveis que expressam a situação hídrica do solo. Estas foram 
computadas separadamente, para cada fase fenológica. Com o modelo desenvolvido, simulou-se o efeito do déficit e do excesso hídrico sobre o rendimento da cultura.

As variáveis que melhor se adequaram ao propósito do trabalho foram o déficit hídrico, expresso em forma de déficit da evapotranspiração relativa, (1-ETa/ETm), e o excesso de água no solo, expresso em forma de um índice desenvolvido (FEX), que considera, de forma crescente, o número de dias consecutivos em que a cultura permanece sob excesso hídrico. A aplicação de modelos, envolvendo apenas variáveis relacionadas ao excesso ou ao déficit de água isoladamente, não apresentou boa correlação, porém, quando em conjunto, os índices estatísticos foram adequados. Tanto o déficit de água como o excesso mostraram-se importantes condicionantes do rendimento da cultura. $O$ acréscimo de produtividade possivel com a irrigação (efeito de déficit), simulado com a equação desenvolvida, variou de zero a 10765 (tempo de retorno de 28 anos) e $11271 \mathrm{~kg} / \mathrm{ha}$ (tempo de retorno de 28 anos), para variedades de ciclo normal e precoce respectivamente. Quanto aos efeitos dos excessos, estes variaram de zero a 7158 e $6326 \mathrm{~kg} / \mathrm{ha}$.

Palavras chave: Zea mays, Modelo de produção, Efeito do déficit hídrico, Efeito do excesso hídrico, Irrigação, Efeito da irrigação, Balanço hídrico. 


\title{
MATHEMATICAL MODEL TO EVALUATE WATER EFFECTS ( DEFICIT AND EXCESS) ON CORN YIELD IN SANTA CATARINA, BRAZIL.
}

\author{
Author: ANTÔNIO SÉRGIO SOARES \\ Adviser: Prof. Dr TARLEI ARRIEL BOTREEIL
}

\section{SUMMARY}

Irrigation has been a fundamental technological resourse to attain good crop yielding, and oustanding in dry regions. Despite rainfall occurrences in enough amounts in humid or subhumid regions it often occurs with unsuitable temporal distribuitions. Such distribuition provokes both water deficit and excess periods in soil, both harmful to good development and causing instability as to crop performance. The uncertainty regarding such phenomena occurrence prevents farmers from investing in irrigation projects. In order to lessem that problem this work studies the effects of water deficit and excess on mayze crop yelding in Urussanga, Santa Catarina.

A series of data on yield and phenology of mayze crop, normal and precocious cycle, and 28-year climatic data, both collected at Urussanga Experimental Extation, Southern Santa Catarina region, was used. Also information on physical-hydrical characteristics of soil were used. Through data on climate, crop phenology and soil a water balance was performed, excepting hydric variables which were correlated with the crop yielding data for adjustement of the yield equation. To develop the equation, multiple regressions between relative crop yielding déficit $(1-\mathrm{Ya} / \mathrm{Ym})$ and the variables expressing soil water status, separately accounted in each phenological phase, were used. The developed model provided the simulation of the deficit and excess water effects on the crop yielding. 
The variables best suiting the purpose of this work were deficit, expressed as the relative evapotranspiration deficit (1-ETa/ETm) and excess water soil, expressed as developed index (FEX), which considers the nunber of consecutive days the crop remains under water excess as increasing. The applicatin of models involving only variables related to excess or deficit water alone failed to present good correlation, however, statistical indexes were suitable when altogether. Both water deficit as excess were shown important conditions for the crop yielding. The feasible yielding increase through irrigation (deficit effects), simulated by equation ranged from zero to 10765 (28year return time) and $11271 \mathrm{~kg} / \mathrm{ha}$ (28-year return time) for normal and precocious cycle varieties, respectively. As to the excess effects, they ranged from zero to 7158 and 6326 $\mathrm{kg} / \mathrm{ha}$

Key words: Zea mays, Yeld model, deficit water effects, excess water effects, irrigation, Irrigation effects, water balance. 


\section{INTRODUÇÃO}

A irrigação tem sido um dos últimos estágios tecnológicos no sentido de garantir e aumentar os rendimentos dos cultivos, principalmente em regiões úmidas. No entanto, caso não seja adequadamente utilizada os resultados podem não ser os esperados. Projetos com dimensionamento ou equipamentos inadequados podem causar prejuízos por danos às culturas ou ao solo. Além desse aspecto, algumas culturas, quando sob determinadas condições climáticas, podem não ter seu rendimento aumentado quando irrigadas.

Os rendimentos dos cultivos são grandemente influenciados pelas condições climáticas, especialmente pela precipitação, pela temperatura, pela evapotranspiração e sua distribuição que ocorrem durante o ciclo. Culturas sensiveis ao déficit hídrico não são economicamente viáveis sem manipulação genética ou irrigação se se pretende cultivá-las

em locais que apresentam precipitação insuficiente nas fases fenológicas críticas. Por outro lado, o excesso causado pela precipitação também significa problemas para o bom desenvolvimento das culturas. (Pereira, 1982)

Para que a irrigação apresente desempenho adequado, aumentando e garantindo os rendimentos das culturas, deve ser aplicada obedecendo a critérios econômicos, técnicos e de conservação dos recursos naturais.

A irrigação em áreas úmidas obedece aos mesmos critérios utilizados em áreas áridas, porém diferenças de clima e de solo alteram os projetos e o manejo de culturas irrigadas. Nessas regiões, apesar de elas apresentarem alta probabilidade de ocorrência 
de precipitações durante o ano todo, ocorrem também períodos de déficit hídrico. Esses dois fenômenos são de difícil previsibilidade, tornando incertos os seus efeitos sobre o rendimento das culturas. Tais períodos quando coincidem com as fases fenológicas críticas da cultura em termos de água, podem trazer prejuízos.

A maioria das atividades ligadas à irrigação são desenvolvidas para atender a regiões que possuem acentuada sazonalidade na distribuição das precipitações, apresentando períodos com pouca ou nenhuma precipitação. Nesses locais, evidenciamse determinados períodos que praticamente inexistem, tornando certo o efeito da irrigação no rendimento das culturas e quase sempre elevando ou possibilitando o retorno dos recursos investidos. Em regiões com precipitação distribuída ao longo do ano, as previsões são mais incertas; apesar da maior disponibilidade natural de água, em termos médios, normalmente se adotam os mesmos procedimentos para o dimensionamento dos projetos.

Segundo Camp et al (1990), a irrigação em regiões úmidas propicia menor retorno marginal do que em regiões áridas e semi-áridas. Muitas vezes essa tecnologia não será lucrativa, devendo utilizada quando se cultivam produtos de alto valor e/ou direcionadas a estratégias de mercado. É sugerido aos irrigantes considerarem a redução no risco para compensar o investimento na irrigação, utilizando estudos de probabilidade de ocorrência de determinados fatores climáticos, como precipitação, temperatura e radiação, no manejo da irrigação. Nas regiões úmidas, a irrigação deve ser complementar, ou seja, deve complementar a precipitação natural. Devido a tal incerteza nos resultados da aplicação de irrigação, já que não existe uma perspectiva exata de seu efeito no rendimento dos cultivos, muitas vezes os agricultores deixam de investir e são expostos a estiagens e, consequentemente, a prejuízos.

Além dos problemas ligados ao manejo da irrigação, o excesso de água no solo, comum em regiões úmidas, pode trazer efeitos negativos sobre os rendimentos. Um periodo de chuvas suficientemente intenso para provocar excessos no solo, pode dar a 
falsa sensação de que a planta está bem suprida de água, tornando ainda mais difícil a decisão dos agricultores.

Considerando o problema exposto, este trabalho tem como objetivo:

1) O ajuste de modelo de estimativa da produtividade da cultura do milho, em função de parâmetros climáticos e das características físico hídricas do solo.

2 ) O dimensionamento dos efeitos do déficit e do excesso hídrico sobre os rendimentos da cultura.

3 ) O estudo probabilístico do acréscimo de produtividade devido à irrigação. 


\section{2 - REVISÃO DE LITERATURA}

\section{1 - O efeito do déficit hídrico no rendimento das culturas}

O desenvolvimento das plantas é condicionado pelo clima que ocorre durante o seu ciclo de crescimento. Sob condições ideais, sem limitações, e estando os fatores de produção em equilíbrio, a performance das plantas é máxima. Dentre tais fatores, o nivel de suprimento hídrico destaca-se como um dos mais importantes. Quando a demanda de água pelas plantas é maior do que a disponibilidade, a cultura está sob déficit hídrico, e, dependendo da intensidade e da duração, poderá comprometer o rendimento da mesma. O fornecimento de água para as plantas é feito exclusivamente pelo solo, que depende das suas características físico-hídricas, como textura, natureza e organização das partículas.

Após uma chuva ou irrigação, enquanto o solo dispuser de água, a planta mantém-se com um potencial de água alto, próximo ao do solo. Durante o dia, a transpiração faz com que o potencial diminua, pois a taxa de transpiração é maior que o transporte de água para as folhas. No período noturno, os potenciais se igualam, com a planta recuperando o conteúdo de água. Com a diminuição do nivel de água no solo, a recuperação do potencial da planta no período noturno torna-se difícil, atingindo um ponto em que a planta não recupera a turgidez, no ponto de murchamento permanente. (Kramer, 1969)

O primeiro efeito é a desidratação das células, resultando conseqüências sobre o desenvolvimento das plantas, que podem ser reversíveis ou não, dependendo da severidade da desidratação. (Levitt, 1972 ${ }^{1}$, citado por Eastin \& Sullivan, (1981)

\footnotetext{
' LEVITT, J. Responses of plants to environmental stresses. Academic Press, New York, 1972.
} 
O déficit de água nas folhas das plantas faz com que elas percam o turgor das células-guarda dos estômatos. Segundo Slatier (1967), está estabelecido que o aumento do turgor das células guarda provoca a abertura dos estômatos, e que sua diminuição o fechamento. Com os estômatos abertos, ocorrem as trocas gasosas, a entrada do $\mathrm{CO}_{2}$ e a saída de $\mathrm{O}_{2}$ e vapor de água, permitindo, assim, o processo fotossintético. Dessa maneira, conforme Boyer \& Mc Pherson (1975), o processo de produção de fotossintatos e a transpiração são relacionados

Para Eastin \& Sullivan (1981), as folhas são resfriadas com a transpiração e, sob condições ideais de fornecimento de água, a transpiração é rápida. No caso de déficit, as folhas se aquecem e a perda de água diminui, interferindo no processo de fotossíntese.

O processo de fotossíntese torna-se limitado quando ocorre déficit hídrico, devido ao fechamento dos estômatos e à sua redução, em outras atividades da planta. Como os processos de transporte, que tornam o $\mathrm{CO}^{2}$ disponível e permitem a evaporação da água, estão associados, o desenvolvimento das plantas pode ser razoavelmente estimado através da evapotranspiração relativa, ou seja, através da relação ETa/ETm, sendo ETa a aevapotranspiração real e ETm a potencial. (Hanks \& Rasmussen, 1982)

A perda de água, através dos estômatos é importante processo fisiológico, pois permite a entrada de $\mathrm{CO}_{2}$ e a saída de $\mathrm{O}_{2}$. Com a transpiração nas folhas, ocorre a diminuição do potencial de água nas células. Tal diminuição é transmitida progressivamente até a raiz. O decréscimo do potencial nas folhas reduz a fotossintese, que, segundo Slavic $(1965)^{2}$, citado por Crafts (1968), causa o fechamento hidroativo dos estômatos, reduzindo o suprimento de $\mathrm{CO}_{2}$. $\mathrm{O}$ déficit de água na estrutura citoplasmática afeta a atividade enzimática, desidrata a cutícula, a parede epidérmica e a membrana celular, reduzindo a avidez por $\mathrm{CO}_{2}$.

Uma das principais alterações morfológicas que ocorrem nas plantas sob déficit hídrico é a diminuição do índice de área foliar IAF. Segundo Begg \& Turner (1976), a divisão celular não é grandemente afetada pelo déficit, porém, provoca diminuição no crescimento das mesmas. A minimização no desenvolvimento das células acarreta

\footnotetext{
${ }^{2}$ SLAVIC, B. The influence of decreasing hidration level on photossinthetic rate in thalli of the Cancephallum conicum. In: Water stress in plants (B. SLAVIC, ed.), Proc. Symp. Prague, 1963. p. 195. Czech Acad. Sci. Prague, 1958.
} 
diminuição do índice de área foliar, que por sua vez, compromete o desenvolvimento da planta, principalmente no período vegetativo, quando ela não cobre todo o solo. Acrescenta o autor que os danos devidos a este fato, menor IAF, são irrecuperáveis. Com esta afirmação concordam Espinoza (1982) e Eck (1986), que relataram reduções do IAF na cultura do milho sob déficit.

Estudando o efeito do déficit hídrico em milho, Robins \& Domingo (1953), encontraram marcante diferença entre as fases fenológicas, quanto à sensibilidade da cultura. Quando o déficit ocorreu no período de floração, os prejuízos foram de 22 e $50 \%$, para durações de 1 a 2 dias e 6 dias respectivamente, com umidade do solo próxima ao ponto de murchamento permanente.

Claasen \& Shaw (1970) estudaram o efeito do déficit hídrico nas diferentes fases fenológicas da cultura do milho em lisímetros. Como tratamentos, aplicaram déficits com durações de 4 e 8 dias. Para o período vegetativo, determinaram diminuição de 12 a $15 \%$ em relação ao tratamento sem restrições. Quando foi aplicado durante o florescimento, ocorreu diminuição de $53 \%$, e, no período de enchimento dos grãos, $35 \%$. Para os autores existe alta significância entre o déficit hídrico e o rendimento de grãos, principalmente quando ele ocorre no periodo de florescimento.

Com o objetivo de determinar equações de produção que permitam planejar a irrigação em milho e sorgo, Stewart et al (1975) aplicaram déficits nas diferentes fases fenológicas das culturas. Para o milho, obtiveram reduções de rendimento de 0 a $88 \%$, para déficit de $26 \%$, aplicado nas fases de maturação e florescimento, respectivamente. Quanto ao sorgo, os efeitos do déficit não são tão claros, no entanto indicam que, quando ocorre no período de polinização provoca maiores diminuições nos rendimentos. Relatam os autores que o milho possui maior sensibilidade à aplicação de déficits do que o sorgo, principalmente na fase de florescimento.

Espinoza (1982) estudou a resposta de doze cultivares de milho ao déficit hídrico. Aplicou em todos os tratamentos, 32 dias de stress após o inicio da floração. Considerando-se a média de todas as variedades, a queda de rendimento foi de 1465 $\mathrm{kg} / \mathrm{ha}$, aproximadamente $30 \%$ do obtido com irrigação plena. A maior queda registrada por uma variedade individualmente foi de $53 \%$. 
Sob condições naturais quando o fornecimento de água ao solo é exclusivamente proveniente de chuvas, esse efeito também tem sido observado. Berlato et al (1992) estudaram o efeito de variáveis climáticas originais e derivadas sobre o rendimento de soja no Estado do Rio Grande do Sul. Das variáveis testadas, o déficit de evapotranspiração foi o que apresentou maiores correlações, 89, 86 e 85\%, para os grupos de maturação precoce, médio e tardio respectivamente. Camargo (1986) também encontrou correlações variando de 76 até $87 \%$ com o modelo de produção, no qual participou o déficit hídrico, e o rendimento da soja para o estado de São Paulo. Aguinski et al (1988), baseado em dados de rendimento de milho e de precipitação ao longo do ciclo e das fases da cultura, encontraram correlações de 93 e 95\% entre a lâmina precipitada e o rendimento. Considerando o déficit de evapotranspiração como um índice de déficit, Medeiros et al (1991) estudaram a dependência existente entre este índice e o rendimento de milho. Realizaram regressões, entre este índice determinado para várias fases fenológicas da cultura, e o rendimento observado, obtendo correlações de 74 e $53 \%$ para os períodos compreendidos entre 10 dias antes do pendoamento e 10 dias após, e para todo o ciclo, respectivamente.

Matzenauer (1994) desenvolveu modelos de produção para estimar o rendimento de milho através da disponibilidade hídrica dos solos. Baseou-se em experimentos realizados em quatro locais com $31,13,24$ e 21 plantios, e dados climáticos respectivos. Como variável independente utilizou a evapotranspiração relativa, ETa/ETm em quatro fases fenológicas da cultura, e como dependente a relação entre o rendimento observado e o máximo ou potencial, Ya/Ym. Quando as variáveis foram ajustadas a um modelo aditivo, as correlações foram de $0,834,0,976,0,880$ e 0,706 , para os quatro locais respectivamente. Com o modelo multiplicativo, os valores foram de $0,789,0,966,0,829$ e 0,7034 . O autor reuniu os dados dos quatro locais em uma só equação, obtendo correlações de 0,766 e 0,731 para os modelos aditivo e multiplicativo, respectivamente. 


\subsection{O efeito do excesso hídrico no rendimento das culturas}

A umidade do solo condiciona intensamente o desenvolvimento das plantas, podendo propiciar não só rendimentos compensadores como também sérias frustrações. Apesar de as plantas possuírem mecanismos que permitem sobreviver e até mesmo produzir razoavelmente numa ampla faixa de umidade do solo, freqüentemente elas estão sujeitas a condições não ideais, quer seja por deficiência, quer por excesso. Em regiões úmidas, sob condições naturais as culturas são freqüentemente afetadas por excessos, quer seja durante inundações, quer seja na simples saturação do solo devido a longos períodos de chuva.

$\mathrm{O}$ excesso de água diminui as trocas de ar entre a atmosfera e o solo. A deficiência de $\mathrm{O}_{2}$ causa diminuição da respiração e do volume total das raízes, comprometendo o transporte de nutrientes e aumentando a formação de substâncias tóxicas no interior do solo e das plantas. Quando o excesso estende-se por vários dias, pode provocar danos irreversíveis para a planta, e até a morte, dependendo da espécie vegetal e da fase fenológica em que se encontra. Solos com excesso hídrico apresentam deficiência no fornecimento de nitrogênio para as plantas. $\mathrm{O} \mathrm{O}_{2}$ é requerido para a mineralização da matéria orgânica pelos microorganismos, e sua deficiência reduz a atividade microbiana, diminuindo suprimento de $\mathrm{NH}_{3}{ }^{+}$e $\mathrm{NO}_{3}$. para as plantas. (Wesseling, 1974).

Woudt \& Hagan (1957) relatam experimentos realizados com lisímetros, quando verificaram que a ausência de $\mathrm{O}_{2}$ nas raizes diminuiu a taxa de fotossíntese, aumentou a respiração e diminuiu a transpiração. Para os autores, a queda da taxa de transpiração reflete a dificuldade das plantas em absorver água de solos inundados e, como consequiência, também diminui a absorção de nutrientes. Letey et al (1962) também relatam diminuição na transpiração da planta, e apontam que a única maneira de alterar a situação é drenando a área.

Letey et al (1962) estudaram o efeito da ausência de $\mathrm{O}^{2}$ confinando as raizes de algodão, feijão e girassol em uma câmara de nitrogênio por vários períodos de duração. 
Relatam diminuições significativas no crescimento quando o tratamento teve duração de 3 dias no período vegetativo, com as raízes cessando o crescimento.

Para Millar (1974), o índice de aeração mais utilizado é a taxa de difusão de oxigênio, TDO. Para a maioria das plantas o crescimento é retido com valores abaixo de $20 * 10^{-8} \mathrm{~g} \mathrm{O}_{2} \mathrm{~cm}^{-2} \mathrm{~min}^{-1}$. Acrescenta o autor que tal valor é variável conforme a espécie vegetal, sendo $15^{*} 10^{-8}$ para a cevada, $30^{*} 10^{-8}$ para o milho e $20^{*} 10^{-8} \mathrm{~g} \mathrm{O}_{2} \mathrm{~cm}^{-2} \mathrm{~min}^{-1}$ para o girassol.

Sigh \& Guildyal (1980) mediram o índice citado por Millar (1974) em solo alagado com $5 \mathrm{~cm}$ de profundidade, em cultura de milho. Verificaram que ocorre diminuição drástica em poucas horas de submergência do solo. Uma TDO inicial de $83 * 10^{-8} \mathrm{~g} \mathrm{O}_{2} \mathrm{~cm}^{-2} \mathrm{~min}^{-1}$ diminuiu para quase zero, com o aumento do tempo de submergência. Após 4 horas a TDO foi de $50^{*} 10^{-8} \mathrm{~g} \mathrm{O}_{2} \mathrm{~cm}^{-2} \mathrm{~min}^{-1}$, atingindo quase zero em 32 horas, $3.5^{*} 10^{-8} \mathrm{~g} \mathrm{O}_{2} \mathrm{~cm}^{-2} \mathrm{~min}^{-1}$. Na parcela controle, o indice manteve-se inalterado.

Em regiões úmidas o lençol freático varia constantemente. Após uma chuva que preencha complemente os poros do solo, as raizes ficam com restrições quanto ao fornecimento de oxigênio. Caso essa saturação do solo perdure além de determinado período de tempo, a planta começa a ter sua fisiologia afetada, diminuindo o seu rendimento. Segundo Wesseling (1974), as espécies diferem largamente quanto à resposta a condições ambientais nas raízes. Sob condições de campo, o sistema soloplanta varia constantemente, quer seja por crescimento e alterações das raízes, quer pela alteração da umidade e da situação física do solo. Para expressar tal complexidade, é necessário integrar todos os fatores no tempo e no espaço. Para o autor, a profundidade do lençol freático é um dos fatores que propicia certa integração, pois apesar de não influenciar diretamente o crescimento das plantas, indiretamente determina as condições de umidade, aeração e propriedades térmicas do solo.

Sieben $^{3}$, citado por Weesseling (1974), baseado em dados de variação de lençol freático em polders da Holanda, desenvolveu um método para quantificar o efeito dessa

\footnotetext{
${ }^{3}$ SIEBEN, W.H. Het verbaund tussen ontwatering en opbrengst bij de jonge zavelgronden in de Noordoostpolder. Van Zee tot land. 40, Tjeenk Willink V, Zwolle, The Nederlands, 1964.
} 
flutuação sobre o rendimento dos cultivos. Considerou que o efeito negativo do excesso de água poderia ser representado pela integração da elevação do lençol freático no tempo, acima de $30 \mathrm{~cm}$ de profundidade. Denominou este índice de $\mathrm{SEW}_{30}$ (Sum of excess water), que é expresso como a somatória das diferenças entre o limite de $30 \mathrm{~cm}$ e a profundidade do lençol medida. Os valores negativos são desprezados. A profundidade de $30 \mathrm{~cm}$ tem sido utilizada com o milho, porém outros valores são utilizados, conforme a cultura. Valores de SEW altos indicam deficiência de drenagem.

$O$ efeito do excesso hídrico sobre o rendimento dos cultivos depende da fase fenológica em que o stress é imposto. O mesmo stress aplicado em fases diferentes, trará conseqüências diferentes sobre a performance das plantas.

Com o objetivo de conhecer o efeito de vários tempos de submergência em diferentes fases da cultura do milho, Ritter \& Beer (1969) aplicaram lâmina de água de $15 \mathrm{~cm}$ nas parcelas por períodos de 24, 48, 72 e 96 horas, nas diversas fases fenológicas da cultura. Os efeitos no decréscimo de rendimento foram maiores quando a inundação ocorreu em plantas com $15 \mathrm{~cm}$ de altura, 20 e $35 \%$ para baixa e alta dose de adubação nitrogenada. Após a floração, os efeitos foram menos pronunciados; sob o tratamento de 96 horas, ocorreu redução de $30 \%$. A duração do alagamento teve efeito no rendimento; 96 horas provocaram maiores perdas de produção do que 48 horas, sendo que, para períodos de 1 dia, não se acusaram reduções. Durante os experimentos, observaram que, sob condições naturais, uma inundação de 3,5 dias propiciou queda de $40 \%$ e que as plantas morreram em 4-5 dias nessa condição. Atribuíram tal diferença de comportamento à maneira como foram aplicados os tratamentos, pois, manter uma lâmina de $15 \mathrm{~cm}$ de água sobre o solo, implica perda por percolação profunda, e que durante o trajeto da água no perfil do solo, esta transportava $\mathrm{O}_{2}$ dissolvido. A quantidade atendia parcialmente as necessidades das raizes, o que não ocorria sob condições naturais. Consideraram que a queda de produção foi devida à diminuição da taxa de $\mathrm{O}_{2} \mathrm{e}$ ao aumento de $\mathrm{CO}_{2}$, provocados pela decomposição aeróbica e anaeróbica da matéria orgânica. Após a retirada da cultura, análises de solo apresentaram grande perda de nitrogênio, quando se compararam parcelas que receberam inundações com a testemunha. 
Hiller (1969), estudando o efeito de vários níveis de stress hídrico aplicado nas diferentes fases fenológicas da cultura do sorgo, propôs o conceito de índice de stress diário, (stress day index). Este índice determina o grau de stress imposto durante o ciclo da cultura e pode ser aplicado com o objetivo de manejo de irrigação ou drenagem. Para sua determinação utilizam-se um fator de susceptibilidade e ofator de stress diário. A susceptibilidade da planta é função da espécie e da fase fenológica em que se encontra. $O$ fator de stress é função da intensidade e da duração do stress aplicado. Para o manejo de irrigação, sugere o uso de temperatura da folha e a resistência estomatal; além da taxa de difusão de oxigênio como fator de stress diário do excesso hídrico, propondo também a seguinte equação:

$S D I=\sum_{i=1}^{n}(C S * S D)$

sendo : SDI - o índice de stress diário;

CS - o fator de susceptibilidade da cultura;

$\mathrm{SD}$ - o fator de stress diário $\mathrm{e}$

$\mathrm{n}$ - o número de fases fenológicas.

A produtividade das culturas é afetada tanto pelo déficit quanto pelo excesso de água no solo. No entanto, os esforços de pesquisas para se conhecer a resposta ao excesso é bem menor quando comparados com os despendidos para estudar os efeitos da deficiência, (Woudt \& Hagan, 1957) e (Radunovich, 1987 e 1990). Tal constatação é comprovada pela quantidade de trabalhos realizados com manejo de água no solo: a grande maioria trata dos efeitos positivos da aplicação de água, enquanto o manejo do excesso proveniente de chuva ou irrigação tem sido estudado com menor intensidade.

Hardjoamidjojo et al, (1982), com base no conceito de "índice diário de stress", proposto por Hiller (1969), estudaram o efeito da flutuação do lençol freático no rendimento do milho. Para quantificar o excesso de água no solo, aplicaram os conceitos de SEW 30 , sendo que as diferenças obtidas foram multiplicadas por fatores de 
sensibilidade da cultura ao excesso hídrico, desenvolvidos por Hiller et al (1974) para 3 fases fenológicas da cultura. Encontraram correlações de $74 \%$ entre o índice utilizado e o rendimento relativo. A equação obtida foi aplicada sobre dados independentes oriundos de 3 locais diferentes. O ajuste desta aos dados independentes foi de 68,86 e $14 \%$, todos sob o limite de confiança de $95 \%$. Mesmo originários de regiões climaticamente diferentes, quando se reuniram os dados dos 4 locais, tanto os utilizados para ajustar a equação, quanto os independentes, a correlação foi de $75 \%$.

Howell et al (1976), estudaram em lisimetro, o efeito de inundações na cultura do sorgo. Como tratamento inundaram os lisímertros por um período de 12 dias em 3 fases fenológicas diferentes. Os efeitos na redução dos rendimentos foram maiores quando aplicadas no início da fase vegetativa, com redução de $30 \%$; já no inicio da formação das paniculas, a redução foi de $26 \%$, enquanto no enchimento dos grãos, não se verificou diminuição significativa.

Testando a resistência de 5 variedades de milho à submergência, Sigh \& Guildyal (1980), aplicaram lâmina de $5 \mathrm{~cm}$ de água, por períodos de 24,48 e 72 horas, 27 e 56 dias após o plantio. Na submergências aos 27 dias, durante 24 horas, não apresentaram diminuições significativas de rendimento; já durante 48 horas, a queda foi de $17.8 \%$, e de $22 \%$, para 72 horas. No tratamento aplicado aos 56 dias após o plantio, somente a submergência de 72 horas foi significativa, com $17.6 \%$ de diminuição.

Mukhtar et al (1990), determinaram coeficientes de susceptibilidade para a cultura do milho, através de lisímetrros. Os tratamentos de inundação das parcelas foram aplicados por um periodo de 10 dias consecutivos, em três etapas da cultura: no início da fase vegetativa, aos 36 dias; antes da floração, aos 56 dias; após a floração, aos 76 dias, e na formação da colheita, aos 100 dias após a semeadura. Para determinar os fatores de susceptibilidade, dividiram a diferença entre o rendimento potencial (tratamento sem inundação), e o rendimento com inundação, pelo rendimento potencial. Os valores obtidos foram, 0,64 e 0,44 para o os tratamentos aplicados aos 36 e 56 dias após a semeadura respectivamente. Após a floração, 0,15 e 0,19 para 76 e 100 dias após a semeadura respectivamente. Com os coeficientes determinados, o autor calculou o índice $\mathrm{SEW}_{30}$, com dados de flutuação do lençol freático coletados próximo aos lisímetros. 
Com eles, obteve equação linear para estimativa dos rendimentos relativos. com correlações entre 60 e $86 \%$.

Analisando dados de resposta da cultura do milho e soja ao excesso hídrico, Evans et al (1990), propuseram utilização de coeficientes de susceptibilidade normalizados. A normalização é feita igualando-se a 1 a soma dos coeficientes para todas as fases. Afirmam os autores que tal modificação isola os efeitos de outros fatores que atuam no processo. Seguindo esses princípios, Evans et al (1991), estudaram resultados de 5 autores, sendo 4 sobre o efeito do excesso hídrico em milho e 1 em soja. Com o índice $\mathrm{SEW}_{30}$ calculado para os dados dos quatro locais agrupados, obteve equações com correlações de $70 \%$ para milho e $67 \%$ para a soja.

O periodo em que o solo fica submerso tem apresentado efeito positivo quanto à diminuição dos rendimentos. Logo após a inundação, o solo mantém ainda uma determinada quantia de $\mathrm{O}_{2}$ dissolvido, que é consumido pelas raízes das plantas e pelos microrganismos. Ahmad \& Kanvar (1991) saturaram o solo com a elevação do lençol freático a $0 \mathrm{~cm}$ de profundidade, em intervalos regulares, e com durações de 3,6 e 9 dias, resultando em um SEW 30 de $90,180,270$ e $360 \mathrm{~cm}$-dia. Comparando com a parcela de controle, a penalização do rendimento em relação ao número de dias em que durou a submergência foi de $27.1,34.2,44.7$ e $51.1 \%$, respectivamente para as durações de 3,6 , 9 e 12 dias, obtendo-se equação linear com correlação de $99 \%$ entre a duração da submergência e o rendimento relativo obtido.

Chaudary et al (1975), relataram diminuições significativas do rendimento quando a cultura do milho foi sujeita a crescentes dias de submergência. Considerando o rendimento obtido com o lençol freático situado a $60 \mathrm{~cm}$ como o máximo, o autor encontraram diminuições de 20.5, 36.1 e 45.5\%, quando a submergência ocorreu aos 14 dias, com duração de 2, 3, 4 dias, 11.8, 24.3 e 36.4\% quando aos 28 dias, e 7.3, 21.4 e $32.5 \%$ quando aos 56 dias após a semeadura. Períodos de submergência de 1 dia não apresentaram efeitos significativos.

Evans et al (1990), aplicando submergência por periodos de 2, 4, 6 e 8 dias consecutivos, encontraram coeficientes de susceptibilidade de $0.29,0.53,0.51$ e 0.56 , quando aplicado o tratamento aos 24 dias, e $0.27,0.41,0.50$ e 0.59 , aos 47 dias. Em 
outra seqüência com submergências de 10 dias consecutivos, os valores determinados foram: $0.32,0.35,0.57,0.35$ e 0.12 , para tratamentos aplicados aos $18,36,56,76$ e 100 dias após a semeadura.

Para Doorenbos \& Kassan (1994), a cultura do milho propicia os melhores rendimentos quando cultivada sob solos bem drenados, devendo-se evitar encharcamentos. A sensibilidade ao encharcamento é maior no período de florescimento e de formação da colheita. Relatam os autores que, quando o encharcamento é aplicado no florescimento, pode reduzir os rendimentos em até $50 \%$ ou mais.

Parece estar amplamente determinado que o excesso hídrico influencia negativamente os rendimentos dos cultivos, e que, quanto maior a sua duração, maior o prejuizo causado. Para a cultura do milho, submergência ou saturação do solo por um período de 1 dia não causam diminuição dos rendimentos. Quando o excesso ocorre na fase vegetativa os efeitos são significativos, podendo comprometer seriamente os rendimentos. Após o período do florescimento, os efeitos são amenizados, causando pequenos prejuízos.

\section{3 - O efeito da irrigação sobre o rendimento das culturas}

A irrigação tem sido um dos últimos estágios tecnológicos no sentido de garantir e aumentar os rendimentos dos cultivos. No entanto, caso não seja adequadamente utilizada os resultados podem não ser como os esperados: i) não responde economicamente por dimensionamento, uso indevido de determinado equipamento ou sistema, ou mesmo porque os rendimentos da cultura não respondem à aplicação de água via irrigação; ii) propicia danos ao solo, comprometendo os rendimentos, e consequentemente trazendo prejuízos individuais e coletivos.

O objetivo da irrigação é o fornecimento de água para as plantas através de meios artificiais, permitindo que se faça agricultura em regiões áridas, e que se evitem secas em regiões semi-áridas e semi-úmidas. (Stewart \& Nielsen, 1990).

Para Bernardo (1984), em regiões áridas, onde a água é fator limitante, deve-se procurar obter rendimentos máximos para cada unidade de água aplicada. Em outras 
situações, sugere que se busque o máximo rendimento por unidade de área ou por custo de mão de obra, conforme as características da situação.

O rendimento máximo possível de uma cultura é determinado pelas condições climáticas e pelo seu potencial genético. Para atingir tal limite, é mister a consonância entre os aspectos técnicos da aplicação da água e as necessidades biológicas das culturas. Portanto, a eficiente utilização da água na produção das culturas só poderá ser alcançada quando os recursos técnicos estiverem orientados com o propósito de suprir, em quantidade e no tempo adequado, as necessidades hídricas da cultura. (Doorenbos \& Kassan, 1994)

A irrigação em áreas úmidas obedece aos mesmos critérios utilizados em áreas áridas, embora diferenças de clima e solo alterem os projetos e o manejo de culturas irrigadas. Em regiões úmidas, o manejo é mais complicado devido à alta probabilidade de precipitação. (Camp et al 1990).

Quando a irrigação se faz para complementar a precipitação natural, os seus efeitos no rendimento dos cultivos não são tão claros quanto quando são feitos em regiões secas. A incerteza da precipitação ou sua ausência, fazem com que os agricultores não invistam em novas tecnologias.

As tecnologias hoje disponíveis para a cultura do milho no Brasil são, em sua maioria, destinadas a cultivos sem irrigação, com rendimentos esperados de 4000 a 6000 $\mathrm{kg} / \mathrm{ha}$. Para lavouras irrigadas, a expectativa é de que se atinjam em média $8000 \mathrm{~kg} / \mathrm{ha}$. (Empresa Brasileira de Pesquisa Agropecuária 1993). Segundo Doorenbos \& Kassan (1994), o milho utiliza eficientemente a água, sendo a cultura de grãos com maior potencial de rendimentos. Sugerem também que, em lavouras irrigadas para fins de comercialização, rendimentos entre 6000 e $9000 \mathrm{~kg} / \mathrm{ha}$ são considerados bons.

Espinoza et al (1980) pesquisaram o efeito da irrigação suplementar em 3 cultivares de milho na região do cerrado brasileiro, em latossolo vermelho escuro. Como tratamento, irrigou as parcelas quando o potencial de água do solo atingiu $0.6 \mathrm{bar}$. Na variedade mais adaptada às condições da região do experimento, o ganho com a irrigação variou entre 1061 e $1466 \mathrm{~kg} /$ ha para o ano em que ocorreu um "veranico" de 
14 a 16 dias, e entre 1239 e $2554 \mathrm{~kg} / \mathrm{ha}$, no ano com déficit de duração de 41 dias, o que significou reduções que variaram entre 20 e $30 \%$.

Considerando a tensão de água no solo de $0,5 \mathrm{~atm}$ como limite para a cultura do milho, Costa et al (1988) aplicaram níveis de deficiência que eqüivaleram a 100, 81.6, $72.5,60.4,46.4$ e $34.6 \%$ daquela tensão. Apesar de não significativos estatisticamente, os quatro primeiros tratamentos variaram entre 6300 e $4700 \mathrm{~kg} / \mathrm{ha}$, com perdas de 18.4 , 27.5 e $39.6 \%$ em relação ao tratamento ideal, 0.5 atm. Os dois últimos, com rendimentos de 2700 e $1000 \mathrm{~kg}$ /ha, significaram uma diminuição de 53.6 e $65.4 \%$.

O milho, como outras culturas, apresenta determinados periodos de seu ciclo com maior ou menor sensibilidade ao déficit hídrico. Neste caso, conforme demonstrado por Robins \& Domingo (1953), Doorenbos \& Kassan (1994), Luuitgards de Moura (1982) e Matzenauer (1994), as fases fenológicas mais sensíveis são o florescimento, seguido das fases de enchimento do grão, do período vegetativo, da maturação e do estabelecimento da cultura.

Assumindo que, para a cultura do milho o período de florescimento é o mais sensível ao déficit hídrico, e, como conseqüência, apresenta maiores respostas à irrigação, Espinoza (1982) testou a resposta de doze cultivares de milho ao déficit hídrico. Como tratamento, suspendeu a irrigação no início do florescimento, por 32 dias. Após esse período, as parcelas voltaram a ser irrigadas. Nas parcelas irrigadas, os ganhos variaram entre 1 e $53 \%$ para a que apresentou menor e maior ganho, respectivamente. O maior ganho absoluto foi de $2053 \mathrm{~kg} / \mathrm{ha}$. Em média, para as 12 variedades, o rendimento foi de 4557, e $3192 \mathrm{~kg} / \mathrm{ha}$, para as parcelas sem e com déficit, respectivamente.

Villegas de los R. et al (1985), estudaram o efeito do déficit aplicado nas fases de pré-florescimento e florescimento. Utilizando 15 variedades, suspenderam a irrigação nesses períodos e obtiveram reduções de 32.7 e 39.7 para os plantios realizados em 1982 e 1983, respectivamente

Stewart et al (1975), através de 8 tratamentos diferentes, aplicaram déficit, em 3 fases fenológicas da cultura, a fase vegetativa, a de florescimento e a de enchimento dos grãos. O maior rendimento obtido foi de $10300 \mathrm{~kg} / \mathrm{ha}$, para o tratamento sem irrigação 
na ultima fase, e o menor, de $1215 \mathrm{~kg} / \mathrm{ha}$, para o tratamento sem irrigação em todo o ciclo, apresentando uma diminuição de $9085 \mathrm{~kg} / \mathrm{ha}$, ou $88 \%$ em relação ao máximo obtido. Para as parcelas sem irrigação no período do florescimento, o rendimento foi de $1220 \mathrm{~kg} / \mathrm{ha}$, com uma redução de $88 \%$ em relação ao máximo obtido.

Em experimento semelhante ao anterior, Music \& Dusek (1980) estudaram o efeito da irrigação em milho. Como tratamento aplicaram nove níveis de déficit hídrico. nas três fases principais da cultura, em 3 anos consecutivos. No ano de 1975, o maior rendimento obtido foi sob irrigação completa em todas as fases, $10850 \mathrm{~kg} / \mathrm{ha}$, quando comparado com o menor, irrigado somente na fase vegetativa, $5670 \mathrm{~kg} / \mathrm{ha}$; o ganho foi de $5180 \mathrm{~kg} / \mathrm{ha}$. Em 1976 e 1977, tratamentos severos provocaram a morte de plantas e rendimento nulo para as parcelas não irrigadas, e os rendimentos máximos de foram de 9750 e $9520 \mathrm{~kg} / \mathrm{ha}$, respectivamente.

Com o objetivo de determinar a relação entre os rendimentos de milho e o consumo de água, Barret \& Scogerboe (1978) impuseram déficit de água nas fases vegetativa e de enchimento dos grãos alternadamente, num total de 8 tratamentos. As parcelas sem déficit atingiram em média $8113 \mathrm{~kg} /$ ha, porém quando a ultima fase não foi irrigada, o rendimento foi de $8403 \mathrm{~kg} / \mathrm{ha}$, resultado semelhante ao relatado por Stewart et al (1975). Quando a irrigação foi aplicada alternadamente na primeira, segunda e terceira fases, os rendimentos foram de 5588,6543 e $5050 \mathrm{~kg} / \mathrm{ha}$, com diminuições de 2815, 1860 e $3353 \mathrm{~kg} / \mathrm{ha}$. Por outro lado, quando os déficits foram aplicados nessas mesmas fases, a situação se inverteu, com rendimentos de 7067, $5769 \mathrm{e}$ 8403, e diminuições de 1336, 2634 e zero para as três fases, respectivamente.

Cassel et al (1985) estudaram e avaliaram o efeito da irrigação suplementar na cultura do milho em região úmida. Os tratamentos com déficit simplesmente não foram irrigados durante todo o ciclo. Os sem déficit foram controlados com tensiômetro e programa de computador. As precipitações durante o ciclo foram de 464, 262 e $220 \mathrm{~mm}$. As diferenças entre os dois métodos de manejo não foram estatisticamente significativas, com rendimentos de 7729 e $8140 \mathrm{~kg} / \mathrm{ha}$. No ano úmido, 1979, o aumento foi de $2450 \mathrm{~kg} / \mathrm{ha}$ : no entanto, nos anos secos, 1980 e 1981 , foi de 6530 e $7060 \mathrm{~kg} / \mathrm{ha}$, respectivamente. Em termos médios, os ganhos foram de $5350 \mathrm{~kg} / \mathrm{ha}$, considerando 
todos os anos e métodos de manejo da irrigação. Consideraram o autores que 3 anos de experimentos não sejam suficientes para representar as precipitações anômalas, e que esta anormalidade dificulta o desenvolvimento de análises de custo-beneficios da aplicação da irrigação.

Rhoads \& Bennet (1990) relatam que produções recordes atingem até 19900 $\mathrm{kg} / \mathrm{ha}$, em nivel de pesquisa e de agricultores; no entanto, a maioria dos irrigantes pode esperar rendimentos entre 11000 e $15000 \mathrm{~kg} / \mathrm{ha}$, e o aumento devido à irrigação varia entre 2500 e $3800 \mathrm{~kg} / \mathrm{ha}$

\section{4 - Modelos de simulação dos rendimentos.}

Os modelos empregados para simular o crescimento e o desenvolvimento das culturas são aproximações que procuram imitar o funcionamento da natureza. Devido à complexidade das relações existentes nos sistemas biológicos, os modelos procuram, através de índices (variáveis), melhor representar determinados processos. $O$ efeito da água sobre as culturas está relacionado com o solo, com a planta e com as condições atmosféricas. O solo, naturalmente com variações na distribuição e organização das partículas, pode armazenar e tornar disponíveis diferentes quantidades de água e nutrientes. As plantas variam quanto à espécie e quanto à fase fenológica em que se encontram e reagem diretamente à disponibilidade de água e à demanda atmosférica.

Segundo Bayer (1979), as equações de produção são simplificações das complexas relações entre o clima e a performance (crescimento e rendimento) das plantas, através de técnicas estatísticas e/ou matemáticas. O mesmo autor propõe uma classificação conforme suas características. Denomina como modelos de simulação do crescimento aqueles que consideram o impacto de variáveis meteorológicas (radiação, temperatura, vento, umidade relativa do ar e outros) em processos específicos como a fotossíntese, transpiração ou respiração, adequadamente simulados por processos matemáticos, baseados em experimentos ou conhecimento de processos específicos. Outra categoria, a qual denomina modelos de análise planta-clima, utiliza dados de umidade do solo, evapotranspiração ou outra variável observada ou derivada com base 
diária e relacionada com dados de morfologia, de desenvolvimento vegetativo ou de rendimento. E, por último, cita os modelos empírico-estatísticos, que se baseiam em amostras de dados de rendimento de uma determinada área, com respectivos dados de clima e solo, que, através de técnicas de regressão, estimam coeficientes. A abordagem não avalia satisfatoriamente a relação causa/efeito, mas é uma metodologia fácil de se empregar, com dados comumente disponíveis.

Sempre que as condições de umidade do solo estão fora do ideal para as plantas, seus rendimentos são penalizados. Segundo Woudt \& Hagan (1957), sob excesso de água as plantas diminuem a transpiração e aumentam a respiração, consequentemente, diminuindo o rendimento. Segundo Hanks \& Rasmussen, 1982, o processo de fotossíntese torna-se limitado quando ocorre déficit hídrico, devido ao fechamento dos estômatos e à redução em outras atividades da planta. Como os processos de transporte, que tornam o $\mathrm{CO}^{2}$ disponivel e permitem a evaporação da água, estão associados, o desenvolvimento das plantas pode ser razoavelmente estimado através da evapotranspiração relativa.

O efeito da irrigação sobre o rendimento das culturas é ha muito tempo conhecido, apesar de, só no último século, ter sido quantificado. Com a escassez de recursos hídricos, o encarecimento da energia e a evolução das técnicas de administração, tornou-se necessário o domínio racional da tecnologia de irrigação. Nas regiões carentes de recursos hídricos, busca-se saber qual o rendimento possível para determinado nível de déficit imposto às culturas. Nas regiões com adequada disponibilidade de água, pretende-se saber se determinada cultura poderá produzir ainda mais que sob precipitação natural e se oferece retornos aos investimentos em tal tecnologia.

Os estudos que relacionaram o rendimento dos cultivos à quantidade de água aplicada têm sido desenvolvidos desde o início do século. Briggs \& Shantz (1913) ${ }^{4}$, citados por Arkley(1963) e por outros autores, desenvolveram trabalhos clássicos sobre consumo de água pelas plantas. Eles, encontraram estreita relação entre a quantidade de

\footnotetext{
${ }^{4}$ BRIGGS, L. J. and SHANTZ, H. L. The water requirements ofplants. I. Investigations in Great Plains in 1910 and 1911. U. S. Bur. Plant Indus. Bul. 284. 49 pp. 1913.
} 
água transpirada durante o ciclo dividida pelo rendimento e a evaporação em tanques. Arkley (1963), trabalhando com os mesmos dados, encontrou relações lineares entre a água transpirada e o rendimento de matéria seca para aveia e cevada.

Briggs \& Shantz $(1914)^{5}$, citados por Jensen (1968) foram os primeiros pesquisadores a observarem que as medidas de consumo de água devem ser consideradas de forma relativa, ou seja, sua relação com o rendimento se dá em forma de déficit de consumo de água. Tal relação, entre o consumo de água expressa em forma de transpiração e a produção de matéria seca, constitui a base para a previsão da produtividade através do stress hídrico.

Hanks \& Rasmussen (1982) citam Cole \& Mathews (1923) ${ }^{6}$, que encontraram relações lineares entre o rendimento de trigo e sorgo e a evaporação em tanque, ETo. Estabeleceram o seguinte:

$$
Y=a+b E T o
$$

onde: Y - Rendimento da cultura;

$\mathrm{a}=$ Constante da equação e

$\mathrm{b}=$ Coeficiente da equação, declividade da linha.

O problema dessa equação é sua especificidade para o local em que foi desenvolvida, ou seja, não considera os efeitos da distribuição temporal da água do ciclo, das diferenças de solo e clima. Essas considerações restringem sua aplicação fora das condições em que foi desenvolvida. (Hanks \& Rasmussen 1982)

De Wit $(1958)^{7}$, citado por Vaux \& Pruitt (1983), apresentou nova relação entre a produtividade das culturas e o consumo de água, sugerindo o uso da relação T/Eo, na forma:

\footnotetext{
${ }^{5}$ BRIGGS, L. J. and SHANTZ, H. L. Relative water requiements of plants. J. Agr. Res. 3, 1., 1914.

${ }^{6}$ COLE, J. S. and MATHEWS, O. R., U. S. Dept. Agric. Bull. num. 1004, 1958.

${ }^{7}$ De WIT, C.T. (1958) Transpiration and Crop Yelds, Versl.Landbouk. Onderz. No. 64, Wageningen, The Netherlands.
} 
$Y=M\left(\frac{T}{E_{o}}\right)$,

onde: $\mathrm{M}$ - fator específico para cada cultura;

T - transpiração da cultura e

Eo - evaporação em tanques.

Para Hanks \& Rasmussen (1982), essa equação significou grande avanço, pois enfatizou a relação T/Eo, ao invés de T/Y, e pode ser aplicada largamente em áreas áridas.

As correlações entre transpiração e produtividade das culturas são altas, porém a dificuldade de se medir a primeira fez com que alguns pesquisadores desenvolvessem relações com a evapotranspiração.

A literatura apresenta muitos exemplos de resposta negativa do rendimento ao déficit hídrico ocorrido em todas as fases. Esse efeito é evidente para muitos cultivos; no caso do milho, Robins \& Domingo (1953) demonstraram que o déficit hídrico ocorrido durante o período da polinização teve especial efeito sobre o rendimento.

Denmead \& Shaw (1960) comprovaram esse efeito e apresentaram evidências de interações entre as condições de stress ocorridas em várias fases de desenvolvimento do milho.

Segundo Vaux \& Pruit (1983), essa dependência do efeito entre as fases, que caracteriza a relação entre o déficit ocorrido em uma fase e o efeito do déficit no rendimento nas fases seguintes, tem sido formulada de duas maneiras, uma de forma aditiva e outra de forma multiplicativa.

Doorenbos \& Kassan(1994) apresentaram uma equação que estima a produtividade relativa, através de dados de evapotranspiração real (ETa) e evapotranspiração potencial (ETm), na seguinte forma:

$$
\left[1-\left(\frac{Y a}{Y m}\right)\right]=K y\left[1-\left(\frac{E T a}{E T m}\right)\right],
$$

onde: $\mathrm{Ya}$ - rendimento real e

Ym - rendimento máximo ou potencial. 
Essa equação considera que existe relação linear entre o rendimento dos cultivos, em sua parte comercializável, e a evapotranspiração. Está implícito também que o déficit hídrico ocorrido em um estágio da planta interfere no estágio seguinte de forma aditiva. Para um rendimento máximo, pressupõe-se um consumo máximo de água, expresso em forma de evapotranspiração, quando ETa/ETm for igual a 1. Com a diminuição da evapotranspiração, em função do déficit de água no solo, com ETa/ETm menor que 1 , espera-se que ocorra uma diminuição proporcional no rendimento. O coeficiente ky representa o coeficiente de proporcionalidade, ou seja, a declividade na linha da produção relativa, em relação à evapotranspiração relativa, sendo, então, um fator de resposta da cultura ao consumo de água e variável conforme fase fenológica da cultura. Os autores apresentam também uma série de coeficientes para várias culturas e para as diferentes fases fenológicas. Dessa maneira, o modelo apresentado considera que a planta possui exigências variáveis com relação à água, ou seja, algumas fases fenológicas consomem mais água do que outras, e sua carência provocará efeitos diferentes nos rendimentos. Para o caso do milho, sugerem os valores de ky de 0,4 para a fase vegetativa, 1,5 para o período de florescimento, 0,5 para o período da formação da colheita, 0,2 para a maturação e 1,25 para o ciclo total da cultura.

Devido a facilidade de aplicação e à adaptação aos mais variados ambientes, tal proposição tem sido utilizada por muitos pesquisadores em várias partes do mundo e com vários objetivos, quer seja para a previsão de rendimentos, para a determinação de melhores épocas de plantio, ou de consumo de água pelas culturas, quer para análises econômicas de sistemas de irrigação.

Serrano et al (1992), utilizando lisímetros de drenagem e à campo estudaram o efeito da irrigação sobre o rendimento de frutos em morangueiro, sob 4 níveis de disponibilidade de água, -0,01, -0,03,-0,05 e -0,07 MPa. Aplicando o modelo proposto acima, e considerando a transpiração como expressão do consumo de água para todo o ciclo e o rendimento máximo o obtido sob a menor tensão, encontrou coeficiente de correlação $r^{2}$ de 0,77 .

Em região de clima sub-úmido, com experimentos à campo e 3 cultivares de soja de ciclo curto, Stegman et al (1990) estudaram as relações entre o consumo de água e o 
rendimento de grãos. Encontraram coeficiente de correlação $\mathrm{r}^{2}$ de $0,44,0,61$ e 0,87 para equação linear, que considerava a evapotranspiração acumulada como parâmetro independente para as 3 variedades, respectivamente. Quando consideraram os rendimentos e evapotranspiração relativos, o coeficiente de correlação $R^{2}$ encontrado foi de 0,91 , mesmo considerando as médias para todas as variedades e com evapotranspiração acumulada para todo o ciclo.

Wenda \& Hanks (1981), analisando dados de rendimento de milho em Utah, USA, encontrou coeficiente de correlação $r^{2}$ de 0,95 e 0,87 para rendimento de matéria seca e de grãos, respectivamente, quando considerou a evapotranspiração para todo o ciclo da cultura. 0 coeficiente ky encontrado foi de 1,33 e 1,46, diferindo do proposto por Doorenbos \& Kassan (1994).

Pedro Junior et al (1983) estudaram dados de produção de 2 variedades de soja, aplicando o modelo proposto por Doorenbos \& Kassan (1994). Para cálculo da evapotranspiração real, e máxima, utilizaram o balanço hídrico proposto por Thornthwaite \& Mather (1955), calculados a cada 10 dias e acumulados para cada fase fenológica da cultura. Os coeficientes ky usados foram os propostos por Doorenbos \& Kassan (1994). Os rendimentos calculados, quando comparados com os obtidos, apresentaram desvios entre 8 e $25 \%$.

Alguns autores, como Hall \& Butcher (1968), Jensen(1968) e Hanks (1974), encontraram relações multiplicativas entre as diversas fases fenológicas, ou seja, que os efeitos do déficit hídrico ocorrido em uma fase interferirão na seguinte de forma multiplicativa.

Jensen \& Sletten $(1965)^{8}$, citados por Jensen(1968), reduzindo o fornecimento de água em 20 e $40 \%$, obtiveram reduções de 35 e $70 \%$, respectivamente, nos rendimentos de grãos de sorgo, ou seja, os rendimentos não tiveram relação linear com a evapotranspiração.

${ }^{8}$ JENSEN, M. E. \& SLETTEN, W. H. Evapotranspiration and soilmoisture-fertilizer interrelations with irrigated grain sorghum in Southern High Plains. U. S. Dept. Agr. Conserv.Res. Rept. 5, 27 pp 
Reconhecendo que o déficit hídrico em determinada fase fenológica da cultura provoca menor diminuição no rendimento do que na evapotranspiração ou transpiração, Jensen (1968), recomenda o seguinte modelo:

$$
\frac{Y a}{Y m}=\prod\left(\frac{E T a}{E T m}\right)^{\lambda}
$$

onde: $\lambda$ - coeficiente para cada fase fenológica da cultura

Estudando o efeito da água aplicada em diferentes fases fenológicas da cultura do sorgo no estado de Nebraska, USA, Camargo (1993), encontrou melhor ajuste do modelo proposto por Jensen (1968), com $\mathrm{R}^{2}$ de 0,90 , quando comparado ao o proposto por Doorenbos \& Kassam (1979), $\mathrm{R}^{2}$ de 0,26.

Matzenauer \& Bergamaschi (1993), trabalhando com milho, determinaram um modelo de produtividade, baseado no déficit de evapotranspiração, ETa/ETm, nas localidade de Taquari e São Borja, RS. Para cálculo da evapotranspiração real e potencial, o autor utilizou os mesmos procedimentos dos dois trabalhos anteriormente citados. Comparando os rendimentos calculados com os obtidos, encontraram um coeficiente de correlação $r^{2}$ de 0,882 e 0,944 para as localidades de Taquari e São Borja respectivamente. Os autores utilizaram a ETa e ETm do período que vai do pendoamento até 30 dias após.

Berlato et al (1992) estudaram a relação existente entre o rendimento de grãos de soja e variáveis meteorológicas. Os dados utilizados são oriundos de 5 locais, num total de 14 anos de experimentos, com variedades de ciclo longo, médio e precoce. Os autores testaram variáveis originais e derivadas. Como originais, utilizaram a precipitação e temperatura média. Como derivadas, a relação entre a precipitação e a evapotranspiracão potencial da cultura (PRE/ETo), e a relação entre a evapotranspiração real da cultura e a evapotranspiração potencial $(\mathrm{ETa} / \mathrm{ETm})$. Dessas variáveis, a que apresentou melhor correlação $\mathrm{r}^{2}$ foi a relação ETa/ETm, com valores $d$ 0.922, 0.928 e 0.944 , na fase de florescimento, para os três grupos de maturação. 
Partindo de dados médios de produção, obtidos por agricultores, Meyer et al (1993) desenvolveram equação de produção para a cultura do milho. Correlacionaram os rendimentos obtidos com o índice ETa/ETm, computados separadamente para 4 fases fenológicas da cultura. Para obtenção das variáveis, utilizou um modelo de balanço hídrico climatológico, sendo a evapotranspiração de referência calculada pela a equação de Penman. No cálculo da evapotranspiração real empregaram um fator de diminuição. obtido em função do esgotamento do solo. Quanto menor a quantidade de água no solo, maior este fator. Como modelo, partiram do proposto por Jensen (1968), obtendo coeficientes para cada uma das fases fenológicas da cultura, $0.058,-0.179,1.539$, e 0.032 , para as fases do desenvolvimento vegetativo, fase imediatamente anterior ao florescimento, e florescimento e enchimento dos grãos. Tais valores concordam com os obtidos por outros autores, como Robins \& Domingo (1953), Stewart et al (1975) e Claasen \& Shaw (1970). Quanto ao coeficiente negativo obtido para a segunda fase, os autores sugerem que o déficit ocorrido nessa fase pode aumentar o rendimento da cultura. O modelo foi desenvolvido com dados de 8 anos, que apresentavam grandes variações de rendimento e de clima, procurando representar as situações extremas. Os índices estatísticos, coeficiente de correlação e índice "d" de Willmot (1981) obtidos, foram 0,791 e 0,928 . A validação, efetuada com dados independentes, apresentou coeficiente de correlação $\mathrm{R}^{2}$ entre 0.319 e 0.756 e índice "d" entre 0.721 e 0.903 . Quando os autores agruparam os dados utilizados para a obtenção do modelo com os utilizados na validação, obtiveram 0.709 e 0.903 , para os dois índices estatísticos, respectivamente.

Além da evapotranspiração relativa, outras variáveis têm sido utilizadas na obtenção de modelos de produção. Retta \& Hanks (1980) estudaram a resposta da irrigação para 7 variedades de milho à campo com umidade do solo e volume de água de irrigação com sonda de nêutrons e pluviômetros, respectivamente. Encontraram coeficientes de correlação $r^{2}$ altos, variando de 0,80 até 0,90 , quando consideraram o rendimento de matéria seca e a evapotranspiração acumulada para todo o ciclo. Para o rendimento de grãos, os valores variaram de 0,79 até 0,92 . Hillel \& Guron (1973) estudaram o consumo de água pelo milho em região seca durante 5 anos. Como tratamento aplicaram lâminas de água de $1.2,1.1,0.75,0.7,0.5$, e 0.4 vezes o consumo 
da planta, expresso em evapotranspiração real. Relatam os autores que o rendimento aumentou linearmente com o aumento na evapotranspiração da cultura

A precipitação pluviométrica tem relação direta com o rendimento das culturas. No entanto, muitas vezes tal efeito não é muito fácil de ser quantificado, pois parte da chuva pode perder-se por escorrimento superficial ou por percolação profunda, ou mesmo, quando em excesso, pode provocar diminuições nos rendimentos. Matzenauer \& Fontana (1987) relacionaram o rendimento do milho com a altura de chuvas totalizadas em diferentes subperíodos da cultura. Os resultados evidenciaram que as melhores correlações ocorreram entre o rendimento e a altura de chuva observada em dois períodos:, de uma semana antes do pendoamento até uma semana após o final do espigamento, e do início no pendoamento até 30 dias após. As correlações foram de 0,763 e 0,785 , para os dois períodos respectivamente, sendo que se empregou, para os cálculos, uma equação polinomial de segundo grau.

Baseados em uma série de dados de chuva e de rendimento de milho, Aguinski et al (1988) desenvolveram um modelo de produção, considerando 5 fases fenológicas da cultura, simultaneamente. Como equação, empregaram um modelo linear e outro exponencial. Os resultados apresentaram coeficientes de correlação $R^{2}$ de 0,93 e 0,95 , para a equação linear e exponencial, respectivamente. A maior sensibilidade da cultura à altura de chuva registrou-se, em ordem decrescente, no período de florescimento, na pósemergência, no desenvolvimento vegetativo e na maturação leitosa.

Numerosos trabalhos têm sido feitos para analisar o efeito do déficit ou do excesso separadamente; por outro lado, poucos são os que relacionam os dois efeitos que penalizam o rendimento conjuntamente. Em uma determinada fase fenológica de uma cultura, um período pode ser afetado pelo excesso e outro, pelo déficit. Caso se analise apenas um aspecto, o resultado acabará distorcido, não se fazendo boa previsão do rendimento. Brunini et al (1982) aplicaram o modelo proposto por Segóvia \& Andrade (1982), a qual estimava os rendimentos através de variáveis que representassem o stress hídrico imposto à planta. Os autores agregaram à proposta original um fator, denominado fator de excedente, que penaliza a produção em função do excesso de água no solo, com a seguinte forma: 
$Y a=Y o(\Pi Z)^{\lambda 2} e^{n(\overline{Z-1}) \lambda 1(F e)^{\lambda 3}}$,

onde : $Z$ - a variável que penaliza o déficit;

$Z$ - o valor médio de $Z$;

$\lambda-1 \ldots 3,-$ os coeficientes das variáveis, $\mathrm{e}$

$\mathrm{Fe}$ - a função do excesso de água no solo, calculada através da seguinte expressão:

$F e=1-\frac{E X C-E T m}{E X C}$

Sendo : EXC o excesso de água no solo e

ETm a evapotranspiração potencial da cultura.

Aplicado-a em dados referentes a soja, o autor obteve correlações $r^{2}$ que variaram entre 87 e 93\%, para 4 variedades cultivadas em 3 locais diferentes. Quando analisadas em conjunto, o $\mathrm{r}^{2}$ foi de $86 \%$, concluindo-se, assim, que a inclusão da variável de excesso hídrico aumentou a precisão das estimativas, particularmente em anos com precipitação elevada.

Com o objetivo de estimar a produtividade potencial de 7 variedades de soja, Camargo et al (1988) aplicaram a mesma metodologia, porém, além de utilizar o déficit de evapotranspiração, conforme a proposta original, introduziram um fator que penalizou os excessos hídricos, desenvolvido por Brunini et al (1982). Para determinação do excesso hídrico, utilizaram o balanço hídrico proposto por Thornthwaite \& Mather(1955). Os autores concluiram que a inclusão do excesso hídrico, como fator de penalização, possibilitou estimar satisfatoriamente a produtividade potencial para as diferentes variedades de soja.

Radulovich (1987) desenvolveu modelo de produção, para uma região tropical, com precipitação entre 1864 e $4063 \mathrm{~mm}$ por ano e temperaturas entre 22.2 e $27.8^{\circ} \mathrm{C}$. 
Utilizou dados climáticos e de produção de arroz, feijão e milho obtidos por agricultores. Considera o autor que o efeito do excesso hídrico tem sido pouco estudado, quando comparado com o déficit. Em regiões tropicais, a maioria da área é cultivada tendo a chuva como única fonte de fornecimento de água, e, ao lado de "veranicos"e distribuição anormal das precipitações, os ciclos das plantas têm sido caracterizados por muito maior precipitação do que evapotrasnpiração. Como variáveis independentes, utilizou o déficit e o excesso hídrico, ambos em bases diárias, ou seja, o número de dias em que a planta ficou sob stress durante o ciclo, com dois formatos:

Índice de excesso:

$I E=\frac{(D E C G C-D D e f)}{D E C G C} \cdot 100$

Índice de stress:

$I S=\frac{[D E C G C-(D D e f+D E x c)]}{D E C G C} \cdot 100$,

Sendo: DECGC - o número de dias do ciclo da cultura;

DDef - o número de dias que a cultura fica sob déficit hídrico e

DExc - o número de dias que a cultura fica sob excesso hídrico durante o ciclo.

Quando o balanço diário do conteúdo de água no solo, entre precipitação, armazenamento anterior e evapotranspiração, apresentava valor superior que a capacidade de campo, era considerado excesso, e, se menor, déficit. Para validação do modelo, compararam-se os resultados estimados com os observados, obtendo-se correlações de 83 e 90\% para a cultura do arroz e 49 e $60 \%$ para a do feijão, nos dois índices respectivamente. Com a cultura do milho, as correlações foram de 61 e $67 \%$ no primeiro, 85 e 87 no segundo plantio. Atribuíram-se as diferenças de performance entre o arroz e outros cultivos à diferença de tecnologia aplicada pelos agricultores. $O$ arroz é predominantemente mecanizado e cultivado por agricultores que possuem grandes áreas, 
em contraste com os que cultivam milho e feijão, geralmente em pequenas áreas e com emprego de tecnologias tradicionais. Agrupando os dados de produção de arroz milho e feijão de forma relativa, ou seja, rendimento real/rendimento máximo, Radulovich (1990) obteve correlações de $87 \%$ com o índice que utilizava o déficit e o excesso de água, simultaneamente. 


\section{3 - MATERIAL E MÉTODOS}

\section{1 - Origem dos dados}

Os dados utilizados neste trabalho são oriundos dos experimentos de competição de cultivares realizados pela EPAGRI, Empresa de Pesquisa Agropecuária e de Extensão Rural de Santa Catarina, na Estação Experimental de Urussanga, região Sul de Santa Catarina. Eles foram conduzidos entre 1975 e 1994. Entre 1982 e 1987, foram conduzidos no município de Içara, distante $22 \mathrm{~km}$ da estação; no ano de 1990, no município de Forquilhinha, distante $30 \mathrm{~km}$, e no ano de 1992, no município de Morro da Fumaça, distante $19 \mathrm{~km}$ daquela estação.

\section{2 - Caracterização do local dos experimentos}

\subsection{1 - Clima}

A Estação Experimental de Urussanga, Região Sul de Santa Catarina, localiza-se na Latitude -28'31"S e Longitude -49'19"W, com altitude de 48,2 m. Essa região foi caracterizada por Althoff et al (1995) como sendo de clima do Grupo C+ - Mesotérmico e do tipo úmido - $f$, com verão quente, conforme classificação de Koeppen.

\subsection{2 - Solos}

Os experimentos foram realizados sobre os solos Içara, Laterítico vermelho distrófico, Typic Paleudults, Morro da Fumaça, Podzólico vermelho amarelo cascalhento epi-eutrófico, Typic Hapludult, segundo classificação realizada por Santa Catarina, 
Secretaria da Agricultura (1973). Além destes, em alguns anos, os experimentos foram conduzidos sobre um solo hidromórfico, não mapeado pelos levantamentos oficiais. Os Quadros a seguir apresentam as características físico-hídricas dos solos.

Quadro 1 - Percentagem de argila, silte e areia, densidade global, umidade em \% peso para tensões de 1/3 e 15 atmosferas do solo Morro da Fumaça.

\begin{tabular}{ccccccc}
\hline $\begin{array}{c}\text { Profundidade } \\
\mathrm{cm}\end{array}$ & $\begin{array}{c}\text { Argila } \\
\%\end{array}$ & $\begin{array}{c}\text { Silte } \\
\%\end{array}$ & $\begin{array}{c}\text { Areia } \\
\%\end{array}$ & $\begin{array}{c}\text { Densidade } \\
\text { Global g/cm }\end{array}$ & $\begin{array}{c}\text { Um 1/3 ATM } \\
\% \text { Peso }\end{array}$ & $\begin{array}{c}\text { Um 15 ATM } \\
\% \text { Peso }\end{array}$ \\
\hline $0-19$ & 39 & 6 & 55 & 1,56 & 27,9 & 15,7 \\
$19-40$ & 43 & 8 & 49 & 1,54 & 29,9 & 15,2 \\
$40-94$ & 38 & 23 & 29 & 1,46 & 36,5 & 23,4 \\
\hline
\end{tabular}

Fonte - Santa Catarina, Secretaria da Agricultura (1973)

Quadro 2 - Percentagem de argila, silte e areia, densidade global, umidade em \% peso para tensões de 1/3 e 15 atmosferas do solo Içara.

\begin{tabular}{ccccccc}
\hline $\begin{array}{c}\text { Profundidade } \\
\mathrm{cm}\end{array}$ & $\begin{array}{c}\text { Argila } \\
\%\end{array}$ & $\begin{array}{c}\text { Silte } \\
\%\end{array}$ & $\begin{array}{c}\text { Areia } \\
\%\end{array}$ & $\begin{array}{c}\text { Densidade } \\
\text { Global g/cm3 }\end{array}$ & $\begin{array}{c}\text { Um 1/3 ATM } \\
\% \text { Peso }\end{array}$ & $\begin{array}{c}\text { Um 15 ATM } \\
\% \text { Peso }\end{array}$ \\
\hline $0-12$ & 64 & 31 & 5 & 1,16 & 42,1 & 24,6 \\
$12-33$ & 65 & 32 & 3 & 1,16 & 23,7 & 12,8 \\
$33-68$ & 66 & 31 & 3 & 1,16 & 38,3 & 31,9 \\
\hline
\end{tabular}

Fonte - Santa Catarina, Secretaria da Agricultura (1973)

Quadro 3 - Percentagem de argila, silte e argila, densidade global, umidade em \% peso para tensões de $1 / 3$ e 15 atmosferas do solo Hidromórfico ${ }^{1}$.

\begin{tabular}{ccccccc}
\hline $\begin{array}{c}\text { Profundidade } \\
\mathrm{cm}\end{array}$ & $\begin{array}{c}\text { Argila } \\
\%\end{array}$ & $\begin{array}{c}\text { Silte } \\
\%\end{array}$ & $\begin{array}{c}\text { Areia } \\
\%\end{array}$ & $\begin{array}{c}\text { Densidade } \\
\text { Global g/cm3 }\end{array}$ & $\begin{array}{c}\text { Um 1/3 ATM } \\
\% \text { Peso }\end{array}$ & $\begin{array}{c}\text { Um 15 ATM } \\
\% \text { Peso }\end{array}$ \\
\hline $0-25$ & 41 & 43 & 16 & 1,26 & 30,64 & 20,22 \\
$25-50$ & 39 & 43 & 18 & 1,45 & 27,32 & 19,85 \\
\hline
\end{tabular}

\footnotetext{
${ }^{1}$ Solo não mapeado pelos levantamentos oficiais.
} 


\section{3 - Dados Experimentais}

Os dados experimentais utilizados neste trabalho foram obtidos por Mondardo ${ }^{2}$, entre os anos de 1975 e 1994. Eles fazem parte dos experimentos oficiais de competição de cultivares de milho e são realizados com um grande número de variedades, que, dependendo de sua performance no ambiente em questão, poderão ser indicadas para serem cultivadas pelos agricultores.

Os dados registrados foram o rendimento em $\mathrm{kg} / \mathrm{ha}$, umidade dos grãos e informações fenológicas, como: data de semeadura, germinação, florescimento masculino e colheita. Anotou-se também informações quanto a ocorrência de eventos climáticos atípicos, como longos períodos de seca ou de chuvas e ataque de pragas ou doenças.

\subsection{1 - Metodologia dos experimentos}

O solo foi preparado de maneira convencional, com arações normalmente na profundidade de $18-20 \mathrm{~cm}$, efetuadas em agosto ou setembro, conforme permitiu o clima, e gradagens e rotativagens próximas à data de semeadura.

A fertilidade do solo foi manejada conforme recomendação oficial de adubação corretiva e de manutenção, seguindo análises de solo. Os corretivos aplicados foram o calcário, o superfosfato triplo e o cloreto de potássio. Como adubação de manutenção e cobertura, utilizaram-se o superfosfato triplo, o cloreto de potássio, o sulfato de amônia e a uréia.

A semeadura foi feita procurando-se obedecer aos períodos recomendados pela Empresa Catarinense de Pesquisa Agropecuária/Empresa de Assistência Técnica e Extensão Rural (1983), que variam de 15 de setembro a 15 de outubro. Como o fornecimento de água foi totalmente dependente de chuvas, em alguns anos, a semeadura

\footnotetext{
${ }^{2}$ Euclides Mondardo, Pesquisador da Estação Experimental da EPAGRI, Urussanga, Santa Catarina Relatórios de Pesquisa, dados parcialmente publicados.
} 
foi feita fora do período recomendado, pois o solo não oferecia condições de umidade para a germinação e o estabelecimento da cultura.

Sempre que necessário, foi efetuado o controle de pragas, doenças e plantas daninhas com defensivos agrícolas ou manualmente.

Os experimentos foram instalados com 3 ou 4 repetições, dispostas em blocos casualizados e látice reticulado ou retangular. Utilizou-se espaçamento de $1 \mathrm{~m}$ x $0,4 \mathrm{~m}$ para as variedades de ciclo precoce, e $1 \mathrm{~m} \times 0,5$, para as de ciclo tardio, ambos os grupos com 10 sementes a cada metro linear, sendo que, posteriormente, foi feito o desbaste, reduzindo para 5 plantas por $\mathrm{m}$. A área útil das unidades experimentais variou de 7 a 10 $\mathrm{m}^{2}$, descontando-se a bordadura.

\subsection{2 - Variedades utilizadas}

Durante os experimentos, as variedades foram sendo substituídas por outras, conforme lançamentos de novas, dessa maneira, durante o período estudado, foram feitas 744 semeaduras, com as variedades tardias, e 561 semeaduras, com as precoces.

Das variedades semeadas, utilizaram-se, neste estudo, as que foram recomendadas para semeadura pelos agricultores. No ano de 1989, não foi semeado o grupo de variedades de ciclo normal devido à ocorrência de seca na época da semeadura, como também, devido ao mesmo motivo, eliminou-se o ano de 1985. Entre as de ciclo precoce, o ano de 1992 por ter sido semeado em local sem informações climáticas. Desta maneira, para o desenvolvimento do modelo, empregou-se dados de 18 e 19 anos para normais e precoces respectivamente. Entre as variedades recomendadas, eliminaram-se as repetições que elevavam o coeficiente de variação acima de $30 \%$; no caso de sobrarem ainda 3 repetições, considerou-se útil a variedade; caso contrário eliminou-se a semeadura daquela variedade. O Quadro 4 apresenta um resumo do número das variedades plantadas e recomendadas por ano, separadas conforme grupo de maturação, em normais ou precoces. 
Quadro 4 - Número de variedades de ciclo normal e precoce plantadas e recomendadas para os anos de 1975-1994.

\begin{tabular}{|c|c|c|c|c|}
\hline \multirow[t]{2}{*}{ ANOS } & \multicolumn{2}{|c|}{ Variedades de ciclo normal } & \multicolumn{2}{|c|}{ Variedades de ciclo precoce } \\
\hline & Plantadas & Recomendadas & Plantadas & Recomendadas \\
\hline 1975 & 42 & 8 & 12 & 2 \\
\hline 1976 & 49 & 10 & 30 & 7 \\
\hline 1977 & 42 & 13 & 25 & 6 \\
\hline 1978 & 30 & 18 & 42 & 11 \\
\hline 1979 & 30 & 13 & 30 & 13 \\
\hline 1980 & 30 & 16 & 30 & 16 \\
\hline 1981 & 30 & 16 & 25 & 14 \\
\hline 1982 & 30 & 14 & 20 & 18 \\
\hline 1983 & 25 & 12 & 20 & 15 \\
\hline 1984 & 25 & 16 & 20 & 19 \\
\hline 1985 & 25 & 17 & 20 & 19 \\
\hline 1986 & 25 & 20 & 25 & 19 \\
\hline 1987 & 29 & 21 & 29 & 23 \\
\hline 1988 & 34 & 25 & 40 & 24 \\
\hline 1989 & - & - & 40 & 12 \\
\hline 1990 & 42 & 18 & 42 & 20 \\
\hline 1991 & 42 & 19 & 30 & 22 \\
\hline 1992 & 60 & 17 & 28 & 18 \\
\hline 1993 & 50 & 3 & 18 & 19 \\
\hline 1994 & 64 & 3 & 20 & 15 \\
\hline TOTAL & 744 & 279 & 561 & 312 \\
\hline
\end{tabular}

\subsection{3 - Informações fenológicas e de rendimento}

Os dados de rendimento das repetições foram corrigidos para a umidade de $14 \%$, e a média passou a representar a semeadura de determinada variedade e ano. $\mathrm{O}$ estudo realizado utilizou as médias das variedades recomendadas a cada ano; dessa maneira, obtiveram-se 18 e 19 dados para as precoces e normais, respectivamente, que são apresentados no Quadro 5. 
Quadro 5 - Ano de semeadura, número de variedades, data de semeadura, rendimento médio (Ya), déficit de rendimento relativo médio (1-Ya/Ym ) das variedades de ciclo normal e precoce utilizadas neste trabalho.

\begin{tabular}{|c|c|c|c|c|c|c|c|c|}
\hline \multirow[b]{2}{*}{ ANO } & \multicolumn{2}{|c|}{ Variedades de } & \multirow{2}{*}{$\frac{\text { ciclo }}{\substack{\mathrm{ya} \\
\mathrm{kg} / \mathrm{ha}}}$} & \multirow{2}{*}{$\begin{array}{c}\text { normal } \\
1- \\
\mathrm{Ya} / \mathrm{Ym}^{1}\end{array}$} & \multicolumn{2}{|c|}{ Var.de ciclo } & \multicolumn{2}{|c|}{ precoce } \\
\hline & $\begin{array}{r}\mathrm{Nu} \\
\mathrm{m}\end{array}$ & $\begin{array}{c}\text { Data de } \\
\text { semeadura }\end{array}$ & & & Num & $\begin{array}{c}\text { Data } \\
\text { semeadura }\end{array}$ & $\begin{array}{c}\text { Ya } \\
\mathrm{kg} / \mathrm{ha}\end{array}$ & $\begin{array}{c}1- \\
\mathrm{Ya} / \mathrm{Ym}\end{array}$ \\
\hline 75 & 8 & $06-$ Nov -75 & 4649 & 0,544 & 2 & $06-\mathrm{NoV}-75$ & 6635 & 0,343 \\
\hline 76 & 10 & 27-out-76 & 4418 & 0,587 & 7 & 27-out-76 & 5295 & 0,498 \\
\hline 77 & 13 & 15-Out-77 & 6318 & 0,446 & 6 & 13-Out-77 & 7312 & 0,333 \\
\hline 78 & 18 & $24-0 u t-78$ & 3459 & 0,706 & 11 & 24-Out-78 & 4065 & 0,639 \\
\hline 79 & 13 & 20-out-79 & 5301 & 0,544 & 13 & 19-Out-79 & 5965 & 0,473 \\
\hline 80 & 16 & $01-N o v-80$ & 5539 & 0,459 & 16 & $01-$ Nov -80 & 5712 & 0,417 \\
\hline 81 & 16 & $30-$ out -81 & 4776 & 0,590 & 14 & $30-$ Out -81 & 5055 & 0,542 \\
\hline 82 & 14 & $06-$ out -82 & 4219 & 0,609 & 18 & $05-$ Out -82 & 4764 & 0,536 \\
\hline 83 & 12 & $01-\mathrm{NOV}-83$ & 3670 & 0,655 & 15 & $01-\mathrm{N} O \mathrm{~V}-83$ & 3145 & 0,691 \\
\hline 84 & 16 & $01-\mathrm{NOV}-84$ & 3626 & 0,669 & 19 & $01-N o v-84$ & 4213 & 0,599 \\
\hline 85 & 17 & $22-$ out-85 & 3690 & 0,624 & 19 & $22-$ Out-85 & 4019 & 0,580 \\
\hline 86 & 20 & $15-$ out -86 & 3829 & 0,642 & 19 & $14-$ Out -86 & 4298 & 0,585 \\
\hline 87 & 21 & $01-$ Dez-87 & 2527 & 0,725 & 23 & $30-$ Out -87 & 3120 & 0,703 \\
\hline 88 & 25 & $26-$ out -88 & 6156 & 0,442 & 24 & $26-$ Out-88 & 7106 & 0,334 \\
\hline 89 & & & & & 12 & $16-$ Nov-89 & 6483 & 0,345 \\
\hline 90 & 19 & $19-$ out-90 & 6335 & 0,463 & 20 & $26-$ Out-90 & 4187 & 0,629 \\
\hline 91 & 18 & 09-out-91 & 7874 & 0,222 & 22 & $15-$ Out-91 & 7410 & 0,237 \\
\hline 92 & 17 & $10-\mathrm{Nov}-92$ & 5241 & 0,463 & 18 & 05-Nov-92 & 2468 & 0,750 \\
\hline 93 & 3 & $05-$ NoV -93 & 4278 & 0,580 & 19 & $08-N o v-93$ & 5301 & 0,481 \\
\hline 94 & 3 & $25-$ Nov -94 & 3194 & 0,673 & 15 & $07-N o v-94$ & 4477 & 0,515 \\
\hline
\end{tabular}

${ }^{\top} \mathrm{O}$ rendimento máximo empregado foi estimado segundo metodologia descrita no ítem 3.4

Durante o ciclo da cultura, observou-se a fenologia, registrando-se a data da semeadura, a de emergência ( momento em que $50 \%$ das plantas de cada parcela haviam emergido do solo), a do início do pendoamento (momento em que $50 \%$ das plantas de cada parcela apresentavam inflorescência masculina visivel) e a da colheita.

\section{4 - Rendimento potencial}

No ajuste das equações de produção, utilizou-se o déficit da rendimento relativo (1-Ya/Ym) como variável dependente, sendo $\mathrm{Ya}$ o rendimento observado e $\mathrm{Ym} o$ 
rendimento potencial ou máximo. Doorenbos \& Kassan (1984) definem o rendimento máximo de uma cultura como o obtido sob condições ótimas de fornecimento de água, nutrientes, com adequado controle de pragas e doenças.

$\mathrm{O}$ rendimento potencial de uma cultura tem sido obtido de várias maneiras. Trabalhando com milho, Meyer et al (1993) e Matzenauer (1984) sugerem o uso do maior rendimento observado como o máximo possível de determinada cultura. Camargo (1993), estudando modelos de produção em sorgo, acresceu $10 \%$ ao maior rendimento observado.

Neste trabalho, para cálculo do rendimento potencial, empregou-se metodologia proposta por Doorenbos \& Kassan (1994), na forma descrita por Barbieri \& Tuon (1992), com as seguintes equações:

$$
Y m=[F c T o y o+(1-F) c T c y c] c L c N c H,
$$

Sendo: $\mathrm{Ym}$ - rendimento potencial ( $\mathrm{kg} / \mathrm{ha} /$ período)

F - fator de correção correspondente à fração de energia disponivel na condição de ocorrência de nuvens, calculado com a seguinte expressão:

$$
F=\frac{(R s e-0,5 R s)}{0,5 b R a},
$$

Sendo : $\mathrm{Ra}$ - radiação extraterrestre $\left(\mathrm{cal} / \mathrm{cm}^{2} /\right.$ dia);

b - coeficiente angular da equação de Angstron;

Rse - a disponibilidade máxima de radiação fotossinteticamente ativa em dias limpos (cal $/ \mathrm{cm}^{2} / \mathrm{dia}$ ), calculado pela seguinte expressão:

$$
R s e=0,5(a+b) R a,
$$

Sendo : a - a constante da equação de Angstron.

A radiação solar global (Rs, $\mathrm{cal} / \mathrm{cm}^{2} /$ dia) foi determinada na Estação Meteorológica da Estação Experimental de Urussanga. Para o período sem 
determinações de radiação solar, desenvolveu-se aqui uma equação baseada em dados disponíveis nos 28 anos de estudo, ou seja, radiação extraterrestre (Ra), temperatura máxima (TMAX), temperatura mínima (TMIN), umidade relativa do ar (UR) e velocidade do vento a 2 metros de altura (V2), com coeficiente de correlação $R^{2}$ de 0,7009 , com a seguinte forma:

$$
R s=a+(R a D I F) b+R a c+T M A X d+T M \mathbb{N} e+D I F^{2} f+U R g+V 2 h+(e s-e a)^{2} i+(T M A X R a) j
$$

Sendo: DIF - a diferença entre TMAX e TMIN;

es - a tensão de saturação de vapor ( $\mathrm{mm} \mathrm{Hg}$ );

ea - a tensão atual de vapor $(\mathrm{mm} \mathrm{Hg})$;

$\mathbf{a}, \mathbf{b}, \ldots \mathbf{j}$ - coeficientes da equação $(a=12,2803, b=0,0269, c=-0,1045, d=0,1666$, $e=-0,2512, f=-0,0173, g=-0,1254, h=0,1021, i=-0,0177$ e $j=0,0101$ )

cTo - fator de correção da temperatura para dias nublados:

$$
\begin{aligned}
& \text { cTo }=-0,279+0,143 t-0,0029 t^{2}, \text { para } 12<=\mathrm{t}<=30 \\
& \text { cTo }=-2,2+0,3575 t-0,0074 t^{2}, \text { para } \mathrm{t}<12 \mathrm{et}>30,
\end{aligned}
$$

Sendo: $\mathrm{t}$ - temperatura média do período $\left({ }^{\circ} \mathrm{C}\right)$

$$
\text { yo - taxa de produção de matéria seca máxima de uma cultura para um dado }
$$
local, em um dia completamente nublado ( $\mathrm{kg} / \mathrm{ha} / \mathrm{dia})$, calculada pela seguinte expressão:

$$
y_{o}=31,7+0,219 R a
$$

cTc - fator de correção da temperatura para dias completamente claros, calculado pela seguinte expressão:

$$
\begin{array}{ll}
c T c=-2,2+0,3575 t-0,0074 t^{2} & \text { para } 12<=\mathrm{t}<=30 \\
c T c=-5,395+0,715 t-0,0145 t^{2} & \text { para } \mathrm{t}<12 \text { e } \mathrm{t}>30
\end{array}
$$


yc - taxa de produção de matéria seca máxima de uma cultura em dia completamente claro (sem nuvens), $(\mathrm{kg} / \mathrm{ha} / \mathrm{dia})$, calculada pela seguinte expressão:

$y c=107,2+0,360 R a$

cL - correção da fotossíntese em função do índice de área foliar (IAF), calculada pela seguinte expressão:

$$
c L=0,0186+0,370 I A F-0,035 I A F^{2},
$$

Sendo o IAF calculado pela equação aqui desenvolvida, a partir de dados de Luitgards de Moura (1982), através da seguinte equação:

$$
L A F=a+b \sum G D+c\left(\sum G D\right)^{2}+d\left(\sum G D\right)^{3}+e\left(\sum G D\right)^{4},
$$

onde : $a, b, c, d$ e c - coeficientes da equação $\left(a=-1,4873, b=0,0097, c=2,2530 \mathrm{E}^{-6} \mathrm{~d}=\right.$ $1,0535 \mathrm{E}^{-8}, \mathrm{e}=3,7746 \mathrm{E}^{-12}$, para variedades de ciclo normal, e $\mathrm{a}=-1,8497 \mathrm{~b}=0,0124, \mathrm{c}=$ $1,160210 \mathrm{E}^{-6}, \mathrm{~d}-1,013 \mathrm{E}^{-8}, \mathrm{e}=4,2612 \mathrm{E}^{-12}$ para variedades de ciclo precoce)

GD - graus-dia, calculados com metodologia descrita em Empresa Brasileira de Pesquisa Agropecuária (1993), que considera as temperaturas máxima e mínima que ocorrem em determinado dia, através da seguinte expressão:

$$
G D=\frac{T M A X+T M I N}{2}-T b,
$$

Sendo : GD - a soma térmica para determinado dia;

TMAX - a temperatura máxima do dia $\left({ }^{\circ} \mathrm{C}\right)$;

TMIN - a temperatura mínima do dia $\left({ }^{\circ} \mathrm{C}\right) \mathrm{e}$

$\mathrm{Tb}$ - a temperatura base $\left({ }^{\circ} \mathrm{C}\right)$. (valor adotado, $\left.10{ }^{\circ} \mathrm{C}\right)$

Quando a temperatura máxima ultrapassar $30{ }^{\circ} \mathrm{C}$, consideram-se apenas 30 e quando a mínima for inferior a $\mathrm{Tb}$, consideram-se 10 . 
cN - correção para os efeitos da temperatura na taxa de respiração:

Para $\mathrm{t}<20^{\circ} \mathrm{C}, \quad \mathrm{cN}=0,6$

$\mathrm{t}>20^{\circ} \mathrm{C}, \quad \mathrm{cN}=0,5$

cH - coeficiente de colheita.

Neste trabalho, o cálculo do rendimento potencial foi feito com acumulação dos cômputos diários durante o ciclo da cultura, com contagem a partir da emergência.

\section{5 - Dados meteorológicos}

Os registros climáticos utilizados foram obtidos na Gerência de Recursos Naturais da Empresa de Pesquisa Agropecuária e Extensão Rural de Santa Catarina, que possui uma rede de estações meteorológicas, instaladas em todas as regiões climáticas do estado, e mantém arquivos obtidos através outras instituições. Os dados destinados ao cálculo da evapotranspiração são provenientes da Estação Meteorológica, localizada nas dependências da Estação Experimental de Urussanga, da EPAGRI. Os de precipitação, da mesma estação, e nos anos de 1982 - 1987, do Posto Pluviométrico do INMET, localizado no município de Içara, distante $22 \mathrm{~km}$ da Estação Experimental. A série de dados com freqüência diária, num período de 28 anos. Os dados utilizados são, Temperatura máxima $\left({ }^{\circ} \mathrm{C}\right)$, Temperatura mínima $\left({ }^{\circ} \mathrm{C}\right)$, Temperatura média $\left({ }^{\circ} \mathrm{C}\right)$, Umidade relativa média (\%), Velocidade do vento a $2 \mathrm{~m}$ de altura do solo $(\mathrm{m} / \mathrm{s})$, Insolação (horas) e Radiação (cal/ $/ \mathrm{cm}^{2} /$ dia). Além desses, usaram-se também dados de radiação extratosférica $(\mathrm{Ra})$ e o número máximo de insolação possível $(\mathrm{N})$, ambos citados por Ometto (1981).

\section{6 - Balanço hídrico}

As variáveis climáticas usadas para o desenvolvimento do modelo de produção, foram obtidas no balanço hídrico do solo, calculado a partir de dados de clima ou destes derivados: precipitação ( $\mathrm{mm})$ e ETo $(\mathrm{mm})$; solo: capacidade de armazenamento de água 
$(\mathrm{mm})$; planta: profundidade das raízes $(\mathrm{cm})$, coeficiente cultural $(\mathrm{kc})$, fator de esgotamento do solo (Fp) e informações fenológicas (datas e durações das fases fenológicas). Destes, obtêm-se o consumo de água, ETm e ETa, o excesso e o déficit. expressos em mm, através da seguinte expressão básica:

$\mathrm{ARM}=\mathrm{ARMant}-\mathrm{ETa}-\mathrm{Dr}+\mathrm{PRE}-\mathrm{PP}$,

Sendo ARM - o armazenamento de água no dia atual, (mm);

ARMant - armazenamento no dia anterior (mm);

ETa - Evapotranspiração real da cultura $(\mathrm{mm})$;

Dr - drenagem superficial (mm), (desprezada);

PRE - precipitação do dia $(\mathrm{mm})$;

PP - percolação profunda (mm), (desprezada).

O balanço hídrico empregado considerou as variações de armazenamento de água no solo, em função da profundidade das raízes das diferentes demandas da planta, representadas por coeficientes culturais $(\mathrm{kc})$ para cada fase fenológica da cultua. Nos períodos anteriores à semeadura, o kc empregado foi de 0,5 considerando a vegetação existente nas entressafras.

\subsection{1 - Cálculo da evapotranspiração de referência através do método de Penman}

A evapotranspiração de referência representa a taxa de evaporação de uma área extensa, coberta com grama verde e de altura entre 8 e $15 \mathrm{~cm}$, crescendo ativamente, sombreando totalmente o solo e sem escassez de água. (Doorenbos e Kassan, 1984).

Para a estimativa da evapotranspiração de referência, utilizou-se neste trabalho a equação de Penman, na forma citada por Ometto (1981), que possui a seguinte apresentação: 


$$
E T o=\frac{\frac{s}{\gamma} H+E a}{\frac{s}{\gamma}+1},
$$

Sendo : s- a tangente da curva de saturação de vapor $\left(\mathrm{mm} \mathrm{Hg} /{ }^{\circ} \mathrm{C}\right)$;

$\gamma$ - a Constante psicrométrica $\left(\mathrm{mm} \mathrm{Hg} /{ }^{\circ} \mathrm{C}\right)$;

$\mathrm{H}$ - o saldo de radiação (mm);

Ea - o termo aerodinâmico da equação de Penman.

A tangente da curva de saturação vapor foi calculada com a seguinte equação:

$$
s=\left(\frac{6886}{T a^{2}} \frac{5,31}{T a^{2}}\right) e s
$$

Sendo : Ta - a temperatura média $\left({ }^{\circ} \mathrm{K}\right)$;

es - a Tensão de saturação de vapor ( $\mathrm{mm} \mathrm{Hg}$ ).

A Tensão de saturação de vapor é calculada com a equação de Tetens:

$$
e s=4,5810^{\left(\frac{7,5 T}{237,5+T}\right)} \text {, }
$$

Sendo : T - a temperatura $\left({ }^{\circ} \mathrm{C}\right)$.

A constante psicrométrica é calculada pela seguinte equação:

$$
\gamma=\frac{0,241 P}{0,622 L}
$$

Sendo : P - a pressão atmosférica $(\mathrm{mm} \mathrm{Hg})$ e

$\mathrm{L}$ - o calor latente de vaporização (cal/g).

O calor latente de vaporização é calculado pela seguinte equação:

$$
L=597,3-0,566 T \text {, }
$$

Sendo : T - a temperatura média $\left({ }^{\circ} \mathrm{C}\right)$. 
O saldo de radiação é dado por equação obtida por Matzenauer (1981) para a cultura do milho, com a seguinte apresentação:

$$
H=\frac{-3,85+0,751 R s}{59},
$$

Sendo : Rs - radiação solar incidente $\left(\mathrm{cal} / \mathrm{cm}^{2} / \mathrm{dia}\right)$;

A tensão atual de vapor é calculada pela seguinte equação:

$$
e a=\frac{U R}{100} e s,
$$

Sendo : UR - a umidade relativa do ar (\%). ea - a tensão atual de vapor $(\mathrm{mm} \mathrm{Hg})$

O têrmo aerodinâmico, poder evaporante do ar, é calculado pela seguinte equação:

$$
E a=0,35\left(1+0,54 V_{2}\right)(e s-e a),
$$

Sendo : $V_{2}$ - a velocidade do vento a $2 \mathrm{~m}$ de altura do solo $(\mathrm{m} / \mathrm{s})$.

3.6.2 - Equação para cálculo de ETo no período em que não se dispõe de todos os dados para a equação de Penman

A Estação Meteorológica de Urussanga não dispõe de dados para a utilização da equação de Penman em todo o período do estudo. Para tanto, desenvolveu-se uma equação com os dados disponiveis em todo o período de interesse: 
$R a-E T o=a+N c_{1}+\operatorname{TMAX} c_{2}+\operatorname{TMIN} c_{3}+D I F 2 c_{4}+U 2 c_{5}+(e s-e a) c_{6}$,

Sendo: N - Número máximo de horas de sol possíveis para a latitude em questão (horas/dia)

TMAX - Temperatura máxima no dia $\left({ }^{\circ} \mathrm{C}\right)$;

TMIN - Temperatura mínima no dia $\left({ }^{\circ} \mathrm{C}\right)$;

DIF2 - Diferença entre TMAX e TMIN (TMAX - TMIN) ${ }^{2}$

$\mathrm{U}_{2}$ - velocidade do vento a $2 \mathrm{~m}$ de altura $(\mathrm{m} / \mathrm{s})$;

(es - ea) - Déficit de saturação de vapor $(\mathrm{mm} \mathrm{Hg})$;

a - a - constante da equação;

c1 - c6 os coeficientes para cada variável;

$\mathrm{Ra}$ - a radiação no topo da atmosfera $(\mathrm{mm}) \mathrm{e}$

ETo - a evapotranspiracão de referência calculada pela equação de Penman.

A equação foi desenvolvida com dados de 1893 dias, cuja radiação foi medida. Nos Quadros 6 e 7, apresentam-se os coeficientes das variáveis utilizadas como também os índices estatísticos. Para obter-se a ETo do dia, diminui-se da $\mathrm{Ra}$ o valor calculado pela Equação 23.

Quadro 6- Variáveis utilizadas na equação para cálculo da ETo, Constante, Coeficientes c1 até c6, Teste T e nível de significância das variáveis.

\begin{tabular}{lcccc}
\hline Var. ind. & Coeficientes & Desvio padrão & Valor T & Significância \\
\hline Constante & $-12,3203$ & 0,3231 & $-38,1267$ & 0,0000 \\
N & 2,0838 & 0,02637 & 79,0139 & 0,0000 \\
TMAX & $-0,03372$ & 0,0209 & $-16,0885$ & 0,0000 \\
TMIN & 0,3709 & 0,0214 & 17,4606 & 0,0000 \\
DIF2 & 0,0109 & 0,0008 & 12,9874 & 0,0000 \\
U2 & $-0,2284$ & 0,0347 & $-6,5728$ & 0,0000 \\
(es-ea) & $-0,5640$ & 0,0216 & $-26,0314$ & 0,0000 \\
\hline
\end{tabular}


Quadro 7- Análise de Variância dos coeficiente e da equação para estimativa da evapotranspiração para período sem dados para a equação de Penman.

\begin{tabular}{l|c|c|c|c|c}
\hline \multicolumn{1}{c|}{ Fonte } & S Quadrados & G. liberdade & Q. Médio & F & P \\
\hline N & 7792,92 & 1 & 7792,92 & 7970,69 & 0,0000 \\
TMAX & 1254,11 & 1 & 1254,11 & 1282,72 & 0,0000 \\
TMIN & 1024,82 & 1 & 1024,82 & 1048,20 & 0,0000 \\
DIF2 & 200,32 & 1 & 200,32 & 204,89 & 0,0000 \\
U2 & 389,06 & 1 & 389,06 & 397,94 & 0,0000 \\
(es-ea) & 662,52 & 1 & 662,52 & 1677,63 & 0,0000 \\
EQUAÇÃO & 11323,80 & 6 & 1887,29 & 1930,34 & 0,0000 \\
ERRO & 1844,92 & 1887 & 0,9777 & & \\
TOTAL & 13168,70 & 1893 & & & \\
\hline R2 $=\mathbf{0 , 8 5 9 9}$ & \multicolumn{5}{c}{ Desvio padrão da estimativa = 0,9888 } \\
\hline
\end{tabular}

\subsection{3 - Cálculo da evapotranspiração máxima da cultura (ETm)}

Evapotranspiração máxima da cultura, ETm, é o consumo máximo possível pela cultura, em determinado período de seu ciclo. Ocorrerá se condições ótimas forem oferecidas à planta, como fornecimento de água e manejo agronômico adequados. (Doorenbos e Kassan, 1994). Para o cálculo da evapotranspiração máxima da cultura, ETm, utilizou-se seguinte relação:

$E T m=E T o k c$,

Sendo: $k c$ - o coeficiente cultural, que relaciona o consumo de água pela cultura, evapotranspiração máxima (ETm), com a evapotranspiração de referência calculada para grama (ETo), em cada fase fenológica da cultura. 
Os coeficientes culturais $(\mathrm{kc})$ e a definição das fases fenológicas da cultura utilizados foram determinados por Matzenauer (1983), em um periodo de 4 anos, para as condições de Taquari, no Rio Grande do Sul (Quadro 8). O autor determinou o consumo de água pela planta através de lisímeros de drenagem e correlacionou-os com a evapotranspiração de referência estimada pela a equação de Penman, obtendo, assim, os coeficientes para cada fase fenológica da cultura. Os resultados são apresentados no Quadro 9. Para o ajuste dos modelos, procurou-se utilizar as médias obtidas, porém, com o objetivo de melhorar os índices estatísticos, alteraram-se os períodos das fases fenológicas. No Quadro 9, são apresentados os valores de kc e divisão do ciclo que foram empregados neste trabalho.

Quadro 8 - Coeficientes culturais $(\mathrm{kc})$ para as diferentes fases fenológicas da cultura, nos anos de 1976-1977, 1977-1978, 1978-1979 e 1979-1980, e médias, obtidos por Matzenauer (1983).

\begin{tabular}{c|c|c|c|c|c}
\hline Fase & \multicolumn{5}{|c}{ ANOS } \\
\hline Fenológica & $\mathbf{1 9 7 6 - 1 9 7 7}$ & $\mathbf{1 9 7 7 - 1 9 7 8}$ & $\mathbf{1 9 7 8 - 1 9 7 9}$ & $\mathbf{1 9 7 9 - 1 9 8 0}$ & Média \\
\hline P - E & 0,31 & 0,39 & 0,43 & 0,46 & 0,40 \\
E - 30d & 0,42 & 0,61 & 0,53 & 0,62 & 0,54 \\
30d - F & 0,97 & 1,13 & 0,82 & 0,84 & 0,93 \\
F - Es & 1,24 & 1,22 & 1,01 & 1,00 & 1,10 \\
Es - ML & 1,07 & 1,13 & 1,03 & 0,93 & 1,04 \\
ML - MF & 0,82 & 0,79 & 0,95 & 0,60 & 0,78 \\
P - MF & 0,78 & 0,90 & 0,83 & 0,73 & 0,81 \\
\hline
\end{tabular}

Sendo : P - Semeadura; E - Emergência; 30d - 30 dias após a emergência; $\mathbf{F}$ - $50 \%$ das plantas com florescimento masculino; Es - 75\% de florescimento feminino; MLmaturação leitosa; MF- maturação fisiológica. 
Quadro 9 - Fases fenológicas da cultura e valores de coeficientes culturais (kc), para variedades de ciclo tardio e precoce.

\begin{tabular}{l|l|c|c}
\hline Fase & Período $^{1}$ & kc no início & kc no final \\
\hline Fase 1 & P-16d & 0,45 & 0,45 \\
Fase 2 & $16 \mathrm{~d}-48 \mathrm{~d}$ & 0,45 & 0,72 \\
Fase 3 & 48d - F & 0,72 & 1,08 \\
Fase 4 & F - 12d & 1,08 & 1,08 \\
Fase 5 & $12 \mathrm{~d}-36 \mathrm{~d}$ & 1,08 & 0,85 \\
Fase 6 & 36d - MF & 0,85 & 0,62 \\
\hline
\end{tabular}

P-semeadura, 16d - 16 dias após a semeadura, 48d - 48 dias após a semeadura, $\mathbf{F}$ florescimento masculino, (momento em que $50 \%$ das plantas de cada parcela apresentavam inflorescência masculina visível), 12d - 12 dias após o florescimento masculino 36d- 32 dias após o florescimento masculino, e MF - maturação fisiológica.

Considerou-se fixo o intervalo entre o florescimento e a maturação fisiológica, 60 dias, seguindo sugestões de Hanway (1963) e Fancelli (1994). Segundo tais autores, as variações desse período podem ser desprezadas.

\subsection{4 - Determinação da evapotranspiração real (ETa).}

A evapotranspiração real da cultura representa a quantidade de água que a planta consome em forma de transpiração, através das folhas, e a que evapora diretamente da superfície do solo. Esta é função da demanda atmosférica, das condições de umidade do solo e das características da planta (profundidade das raízes e fase fenológica). Permanece igual a ETm, enquanto a umidade do solo não atingir um determinado limite de esgotamento, denominado fator Fp de esgotamento do solo. Segundo Doorenbos \& Kassan (1994), o emprego de um fator de esgotamento de 0,55 tem efeito muito pequeno sobre o rendimento de milho, sugerindo que se utilize 0,4 no período de estabelecimento da cultura, 0,55 a 0,65 no período vegetativo, florescimento e de formação da colheita, $\mathrm{e}$ 0,8 no período de maturação. Com a cultura do milho, Hanks (1974), Dyer \& Bayer (1979) e Meyer (1993) têm utilizado o valor de 0,5. Com sorgo, Camargo (1993) e Camargo (1994) utilizaram 0,5. Neste trabalho empregou-se o valor de 0,5, para os solos Içara, Morro da Fumaça e hidromórfico. 
O cálculo da ETa foi efetuado da seguinte maneira:

$$
\begin{aligned}
& \text { Eta }=\text { Etm } p \\
& p=1, \text { enquanto ARM/CAD }>\text { Fp; } \\
& p=\text { ARM / Fp CAD), se ARM/CAD }<=\text { Fp }
\end{aligned}
$$

Sendo : ARM o armazenamento atual de água no solo (mm);

CAD o armazenamento potencial do solo, "capacidade de campo" (mm).

Nesta metodologia, a ETa será igual a ETm enquanto a água remanescente do solo for maior do que a CAD multiplicado por Fp. Após esse limite, a ETa diminuirá seguindo o valor de $\mathbf{p}$. $O$ valor de $\mathbf{p}$ interfere como fator limitante da ETa, quando a umidade do solo se aproxima do "ponto de murcha permanente", enquanto Fp representa o ponto crítico, a partir do qual a planta não satisfaz plenamente suas necessidades de água. Tal metodologia de cálculo, com emprego de um fator de diminuição da evapotranspiração real, foi utilizada em trabalhos de balanço hídrico do solo por Hanks (1974), Robinson \& Hubbard (1990) e Meyer (1993) com milho, e com a cultura da soja, milho, sorgo, trigo e pastagem, e por Camargo (1993) e Camargo et al (1994), com sorgo, sendo também sugerida por Hill (1991) para manejo de culturas irrigadas.

$\mathrm{O}$ armazenamento potencial do solo foi calculado considerando a profundidade das raízes e as características do solo. Adotaram-se valores de armazenamento de água por $\mathrm{cm}$, conforme o tipo de solo. Para o solo Morro da Fumaça, $1,33 \mathrm{~mm} / \mathrm{cm}$, para o solo Içara, $1,23 \mathrm{~mm} / \mathrm{cm}$, e para o solo hidromórfico, $1,20 \mathrm{~mm} / \mathrm{cm}$. A profundidade das raízes variou da seguinte forma: nos primeiros 15 dias do ciclo ,20 $\mathrm{cm}$ de profundidade; entre $o$ décimo sexto e o vigésimo quinto, variou entre 20 e $40 \mathrm{~cm}$; entre o vigésimo sexto e o trigésimo quinto $40 \mathrm{~cm}$, e entre o trigésimo sexto e o quadragésimo quinto variou de 40 até $60 \mathrm{~cm}$ de profundidade. Deste ponto até a maturação fisiológica $60 \mathrm{~cm}$. Tal procedimento segue sugestão de Matzenauer (1994), que empregou profundidade de 20 $\mathrm{cm}$ nos primeiros 20 dias do ciclo, $40 \mathrm{~cm}$ nos 20 seguintes e 60 no restante do ciclo. 


\subsection{5 - Determinação do excesso e déficit de água no solo}

A região em estudo é classificada como úmida, sendo o excesso um fator condicionante da produtividade. O excesso de água no solo ocorre quando o fornecimento ultrapassa a sua capacidade de armazenamento, ou seja, quando para determinado dia do balanço hídrico, a Equação 14 apresentar valor superior à "capacidade de campo" (CAD)

Normalmente expresso em forma de mm de água, alguns autores têm proposto formas adimensionais para representar o excesso de água, como Brunini et al. (1982) e Camargo (1988).

Segundo dados de Ritter \& Beer (1969) e Hiller (1969), as plantas são diferentemente afetadas, pela duração do período em que ficam sob excesso de água no solo e pela fase fenológica em que se encontram. Com base em trabalhos de Evans et al (1990), Joshi e Dastane (1966) ${ }^{3}$ citados por Evans et al (1990) e Chaudhary et al (1975), propõe-se um índice de excesso que considera o efeito do número de dias consecutivos em que a planta permanece ininterruptamente sob efeito de excesso hídrico. Considerase que os efeitos dos excessos de precipitação sejam iguais aos advindos de inundações, tratamento empregado pelos autores citados anteriormente. Estes estudaram o efeito do número de dias em que a planta fica sob encharcamento, em diferentes períodos do ciclo, sobre o rendimento da cultura do milho. Denominaram como fator de sensibilidade da cultura, a produção relativa obtida com os diferentes tratamentos. Dessa maneira, numa seqüência de dias de excesso, o segundo dia possui peso maior do que o primeiro, assim sucessivamente até o oitavo dia. Deste ponto em diante, o peso diminui. $O$ índice de excesso proposto (FEX) é obtido a cada dia do balanço hídrico, através de equações para as fases vegetativa e reprodutiva. No Quadro 10 apresentam-se os dados utilizados no desenvolvimento deste índice e, na Figura 1, a sua demonstração gráfica.

${ }^{3}$ JOSHI, M. S. \& DASTANE, N.G. Studies in excess water tolerance of crop plants. II Effects of differnt duration of flooding at diferent stages of growth, yeld and quality of mayze. Indian J. Agronomy, 11(1):7079 
Quadro 10- Fator de sensibilidade do milho para vários dias consecutivos de encharcamento do solo em diferentes fases fenológicas da cultura.

\begin{tabular}{|c|c|c|c|c|c|c|}
\hline \multirow{3}{*}{$\begin{array}{c}\text { Dias com } \\
\text { Excesso } \\
\end{array}$} & \multicolumn{6}{|c|}{ Dias após semeadura } \\
\hline & \multicolumn{4}{|c|}{ Periodo vegetativo } & \multicolumn{2}{|r|}{ Reprodutivo } \\
\hline & $14^{\mathrm{a}}$ & $24^{b}$ & $37^{\mathrm{c}}$ & $47^{d}$ & Média & $72^{e}$ \\
\hline 1 & & & 0,18 & & 0,18 & 0,15 \\
\hline 2 & 0,20 & 0,29 & & 0,27 & 0,25 & \\
\hline 3 & 0,37 & & & & 0,37 & \\
\hline 4 & 0,47 & 0,52 & 0,31 & 0,41 & 0,42 & 0,25 \\
\hline 6 & & 0,51 & & 0,5 & 0,50 & \\
\hline 8 & & 0,57 & 0,57 & 0,59 & 0,57 & 0,38 \\
\hline $10^{f}$ & 0,32 & & 0,35 & 0,57 & 0,41 & $0,23^{\mathrm{g}}$ \\
\hline
\end{tabular}

Fontes $={ }^{\mathrm{a}}$, Chaudary et al (1975); ${ }^{\mathrm{d}},{ }^{\mathrm{d}} \mathrm{e}^{\mathrm{f}}$, Evans et al (1990), ${ }^{\mathrm{c}} \mathrm{e}^{\mathrm{e}}$,Joshi e Dastane (1966).

${ }^{g}$, Média entre 0,34 e 0,12 , referentes a 76 e 100 dias após semeadura, respectivamente.

Os dados de média do período vegetativo, coluna 6 do Quadro 9 e os valores do período reprodutivo, coluna 7 , foram colocados em gráfico no eixo das coordenadas e o número de dias de excesso, coluna 1, no eixo das abcissas. Deste, através de interpolações, foram retirados 10 pares de dados, "dias de excesso" e "fator de sensibilidade", para cada período do ciclo, vegetativo e reprodutivo. Com esses dados, através de regressão múltipla, obteve-se duas equações, uma para o período vegetativo e outra para o reprodutivo, equações 25 e 26 e Figura 1:

Período Vegetativo

$F E X=-0,0742+0,3298 N D+-0,0965 N D^{2}+0,0139 N D^{3}+-0,00072 N D^{4}$

Período Reprodutivo

$$
F E X=0,0417+0,01468 N D+-0,0514 N D^{2}+0,0088 N D^{3}+-0,000507 N D^{4},
$$

Sendo : FEX - o índice diário de excesso de água no solo,

ND - o número de dias da seqüência de encharcamento do solo. 
Conforme se pode observar na figura 1, o segundo dia de encharcamento do solo teria um FEX de 0,192 e 0,299 para os periodos vegetativo e reprodutivo, respectivamente.

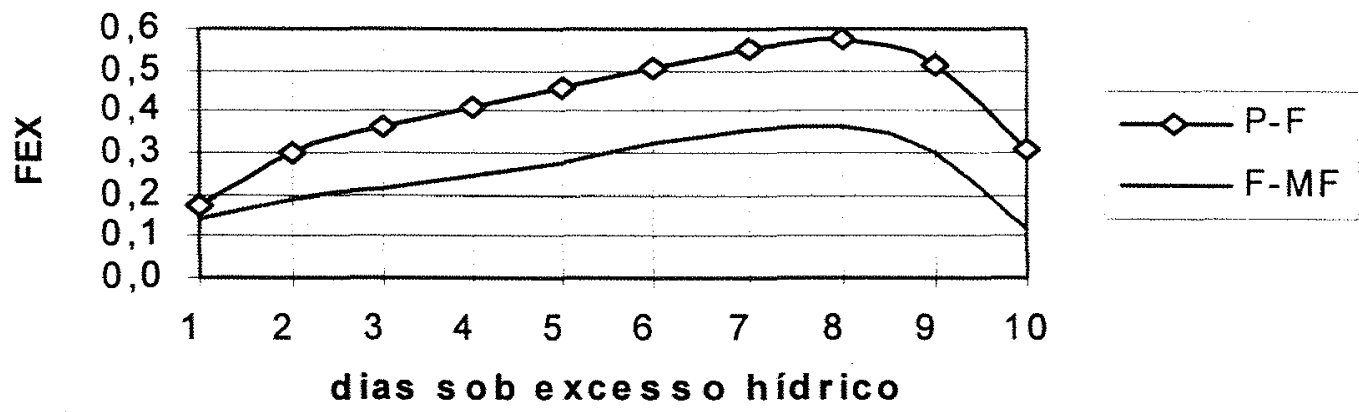

Figura 1 - Índice diário de excesso (FEX) em função do número de dias consecutivos sob excesso hídrico, para o período semeadura- florescimento masculino (P -F) e florescimento-maturação fisiológica (F - MF).

Na região deste estudo, a ocorrência de déficits durante o período em que se cultiva milho foi relatada por Samani e Hargreaves (1985). Através de um "índice de disponibilidade hídrica" de nível mensal, (razão entre a precipitação com $75 \%$ de probabilidade e a evapotranspiração de referência), detectaram valores abaixo de 0,4. Braga (1982), estudando freqüências de ocorrência de dias secos em nível decendial, em região próxima, relata maior ocorrência de dias secos no primeiro e quarto trimestres do ano, período em que o milho se desenvolve. No balanço hídrico empregado, considera-se déficit quando a evapotranspiração real (ETa) for menor do que potencial para a cultura (ETm), que ocorre quando a umidade do solo estiver abaixo do nível estipulado pelo valor de Fp, neste caso, 0,5, para os solos Içara, Morro da Fumaça e hidromórfico..

$\mathrm{O}$ índice mais utilizado para caracterizar o efeito do déficit hídrico tem sido a evapotranspiração relativa, expresso na forma de ETa/ETm. Muitos autores têm utilizado essa relação para dimensionar o efeito do déficit através de equações de produção como Jensen (1968), Hanks (1974), Wenda \& Hanks (1981), Serrano et al (1992), Doorenbos \& Kassan (1994) e Matzenauer (1994). Neste trabalho, 
usou-se a relação 1-ETa/ETm, denominada de déficit de evapotranspiração relativa, sendo que ETm e ETa são totalizados para cada fase fenológica da cultura.

\subsection{6 - Aferição do balanço hídrico}

Para aferir a contabilização das entradas (chuva) e saídas (evapotranspiração e excessos) de água do solo, empregou-se a metodologia citada por Braga (1982), através das seguintes relações:

$\sum E T m=\sum E T a+\sum D E F I C I T$

$\sum \mathrm{PRE}=\sum \mathrm{ETa}+\sum \mathrm{EXCESSO}+\sum \mathrm{ALT}$

$\sum \mathrm{PRE}=\sum \mathrm{ETm}+\left(\sum \mathrm{PRE}-\sum \mathrm{ETM}\right)$,

Sendo : DÉFICIT - o déficit de água no solo em mm.;

EXCESSO - o excesso de água no solo em $\mathrm{mm}$;

PRE- a chuva em mm e

ALT - o somatório das diferenças de armazenamento entre o dia anterior e o atual.

\section{7 - Modelo para estimativa do rendimento de grãos.}

Desenvolveu-se um modelo para estimar os rendimentos da cultura para variedades de ciclo tardio e precoce. Ele foi obtido com regressões múltiplas entre o déficit de rendimento relativo, 1-Ya/Ym, e, como variáveis independentes, o déficit de evapotranspiração relativa, 1-ETa/ETm, e o excesso na forma do índice de excesso FEX, que é a somatória dos índices ocorridos a cada dia, proposto no item 3.6.6, considerados nas 6 fases fenológicas da cultura. A equação utilizada possui a seguinte forma: 


$$
\left(1-\frac{Y a}{Y m}\right)=\left\{\left[\sum_{i=1}^{n} d_{i}\left(1-\frac{\sum E T a}{\sum E T m}\right)_{i}\right]+\left[\sum_{i=1}^{n} e_{i}\left(\sum F E X\right)_{i}\right]\right\}
$$

Sendo : n - o número de fases fenológicas da cultura,

$d_{i}$ - o coeficientes para a variável referente ao déficit hídrico na fase $i, e$

$\mathrm{e}_{i}$ - o coeficientes para a variável referente ao excesso hídrico na fase $\mathrm{i}$.

Para se obter o rendimento em determinado ano, multiplicou-se o valor obtido através da equação pelo rendimento potencial ou máximo (Ym).

Com o objetivo de comparar os coeficientes entre si, as variáveis referentes ao excesso para todos os anos e fases fenológica foram adimensionalizadas conforme sugestão de Falls (1973) pela seguinte equação:

$$
X a=\frac{x-a}{b-a}
$$

Sendo : Xa - a variável adimensionalizada;

$\mathrm{x}$ - a variável original;

a - o menor valor observado em toda a série;

b - o maior valor da série.

\section{8 - Análise estatística}

A validação e o ajuste do modelo aos dados observados, foi verificado com a análise de variância dos coeficientes, como também de toda a equação e teste $T$, conforme Neter et al (1983). Empregou-se também o índice 'd" proposto por Willmott (1981), utilizado para validação de equações por Camargo(1993), Meyer et al (1993), Robinson \& Hubbard (Try, e Camargo et al (1994) como indicadores mais sensíveis da possibilidade de estimativa que a equação possui.

Devido ao número de anos de estudo, 18 para variedades de ciclo precoce e 19 para as tardias, e não se dispondo de outros dados para efetuar a validação, optou-se pela utilização da técnica conhecida como validação cruzada, sugerida por 
Jones \& Camberry (1994). Nesta, retira-se determinado dado da série e determinam-se os coeficientes da equação com os restantes. Com os coeficientes obtidos, estima-se a variável independente do dado que ficou fora da regressão. Repete-se a operação para todos os dados da série e comparam-se as estimativas com os resultados observados. No caso deste trabalho, cada dado representa um determinado ano da série

\section{9 - Determinação dos rendimentos reais no período anterior à série de dados de rendimento}

Após o desenvolvimento da equação de produção, aplicou-se a ela as variáveis obtidas (1- ETa/ETm e FEX) no período anterior ao do desenvolvimento da equação, entre 1965 e 1974, o qual carece de dados de produção observados, estimando-se assim a produtividade da cultura nesse período. O objetivo dessa estimativa é o aumento do número de dados de rendimento real e de ganhos com irrigação para estudos de freqüência.

A data de semeadura deste período, 1965-1974, foi estabelecida a partir da média das datas das semeaduras efetuadas entre 1975-1994. Na definição da data da emergência e do florescimento masculino, empregou-se a soma térmica, somatório de graus-dia, com contagem inicial no dia do semeadura, segundo metodologia descrita no item 3.4. Para variedades de ciclo normal a médias das somatórias de graus-dia foram de 77 e 865 para os períodos compreendidos entre a semeadura e a emergência e entre a emergência e o florescimento masculino. Para as precoces, os valores foram 76 e 800 graus-dia.

\subsection{0 - Determinação do efeito da irrigação (ou do déficit)}

O efeito da irrigação nos rendimentos da cultura foi obtido através dos modelos desenvolvidos. Aplicaram-se, nas equações, as variáveis obtidas com o balanço hídrico, porém considerando nulo o déficit, (1-ETa/ETm igual a zero), permanecendo o índice de excesso de água no solo FEX, como único penalizador do rendimento. Como resultado 
desses cálculos, obtiveram-se rendimentos que não foram afetados pela falta de umidade no solo. Nas fases fenológicas que apresentaram coeficientes negativos, empregou-se os índices 1-ETa/ETm obtidos no balanço hídrico. Destra maneira, não simulou-se irrigação nestas fases.

$\mathrm{O}$ efeito da irrigação foi calculado diminuindo-se o rendimento com déficit do obtido sem tal penalização.

Assumem-se como nulos os eventuais efeitos de excessos hídricos advindos da irrigação, bem como que o rendimento de grãos da cultura do milho começam a ser prejudicados quando a relação entre o armazenamento atual do solo (ARM) e o armazenamento potencial (CAD) for menor que o limite de esgotamento do solo, definido por Fp.

\subsection{1 - Determinação do efeito do excesso hídrico}

$\mathrm{O}$ efeito do excesso hídrico sobre os rendimentos da cultura foram obtidos através da diferença entre o rendimento potencial $(\mathrm{Ym})$ e $\mathrm{o}$ rendimento irrigado. Assume-se que a diferença entre o rendimento potencial e o observado (Ya) é devida aos dois fatores de stress, déficit expressado pelo índice 1-ETa/ETm e excesso pelo índice FEX. Na simulação da irrigação, elimina-se o efeito do déficit, restando os excessos como penalização do rendimento.

\subsection{2 - Estudo de probabilidade de ocorrência}

Obtida a série de dados das estimativas de ganho com a irrigação, dividiu-se em classes e estudou-se uma distribuição teórica que melhor se ajustasse. $O$ melhor ajuste ocorreu com a distribuição Gama. Outros autores têm empregado a mesma distribuição em estudos de precipitação, como Frizzoni (1979) e Saad (1990). Eles apresentam a sua função densidade de probabilidade através da seguinte expressão: 
$Y=\frac{1}{\beta^{\alpha} \Gamma(\alpha)} x^{\alpha-1} e^{-x / \beta}$,

Sendo : $\alpha$ e $\beta$ - os parâmetros de escala e de forma respectivamente;

$\mathrm{x}$ - $\mathrm{o}$ acréscimo de produtividade devido a irrigação;

$\Gamma$ - é o símbolo da função gama.

Os parâmetros alfa e beta da distribuição Gama foram estimados pelo método da máxima verossimilhança, descrito por Haan (1977), através das seguintes equações:

$\beta=\frac{x m}{\alpha}$

$\alpha=\frac{1+\sqrt{1+(4 A / 3)}}{4 A}$

$A=\ln (x m)-\frac{1}{n} \sum_{k=1}^{n} \ln (x)$,

Sendo : $\mathrm{xm}$ - a média dos acréscimos de rendimento;

$\mathrm{x}$ - $\mathrm{o}$ acréscimo de rendimento a cada ano;

$\mathrm{n}$ - o número de anos

As estimativas das probabilidades de ocorrência de que determinado nível de acréscimo de rendimento não seja excedido são dadas pela distribuição acumulada da função Gama incompleta, apresentada por Frizzoni (1979) e Saad (1990), através da seguinte expressão:

$$
P(x)=\frac{1}{\beta^{\alpha} \Gamma(\alpha)} \int_{0}^{x} x^{\alpha-1} e^{-x / \beta}
$$

O cálculo das integrais foi efetuado através de programa de computador com rotina que emprega o método de Newton-Raphson, citado por Kreyszig (1993). O cálculo das integrais por esse método foi efetuado por Frizoni (1979) e Saad (1990). 


\section{RESULTADOS E DISCUSSÃO}

\subsection{Balanço hídrico}

Os resultados do balanço hídrico, expressos na forma de índice de déficit (1ETa/ETm) e de excesso (FEX adimensionalizados) realizado nos 28 anos do estudo, são apresentados no Quadros 12 e 13. Os valores apresentados no Quadro 12 e 13 refletem a variação da umidade do solo durante as fases fenológicas da cultura. Nos 28 anos estudados, o déficit foi mais freqüente em todas as fases. No Quadro 11, apresenta-se o resumo das ocorrências de déficit e excesso de água no solo. Apesar de terem ocorrido déficits e excessos intensos no período reprodutivo, fases 4 a 6 , os déficits foram mais freqüentes no vegetativo, fases 1 a 3 , enquanto que, com os excessos, ocorreu o inverso. Esses resultados refletem a distribuição das chuvas e a demanda atmosférica durante o ciclo.

Quadro 11 - Freqüência de déficits (1-ETa/ETm) e excessos (FEX) no solo nas seis fases fenológicas da cultura para as variedades de ciclo normal e precoce, nos 28 anos do estudo, (1965-1994)

\begin{tabular}{lccccccc}
\hline \multirow{2}{*}{ Ciclo } & & \multicolumn{6}{c}{ Fases fenológicas da cultura } \\
\cline { 3 - 7 } & Stress & $\mathbf{1}$ & $\mathbf{2}$ & $\mathbf{3}$ & $\mathbf{4}$ & $\mathbf{5}$ & $\mathbf{6}$ \\
\hline Normal & Déficit & 23 & 25 & 24 & 21 & 23 & 15 \\
& Excesso & 24 & 24 & 20 & 15 & 19 & 23 \\
\multirow{2}{*}{ Precoce } & Déficit & 22 & 25 & 22 & 20 & 22 & 14 \\
& Excesso & 23 & 23 & 23 & 13 & 21 & 23 \\
\hline
\end{tabular}




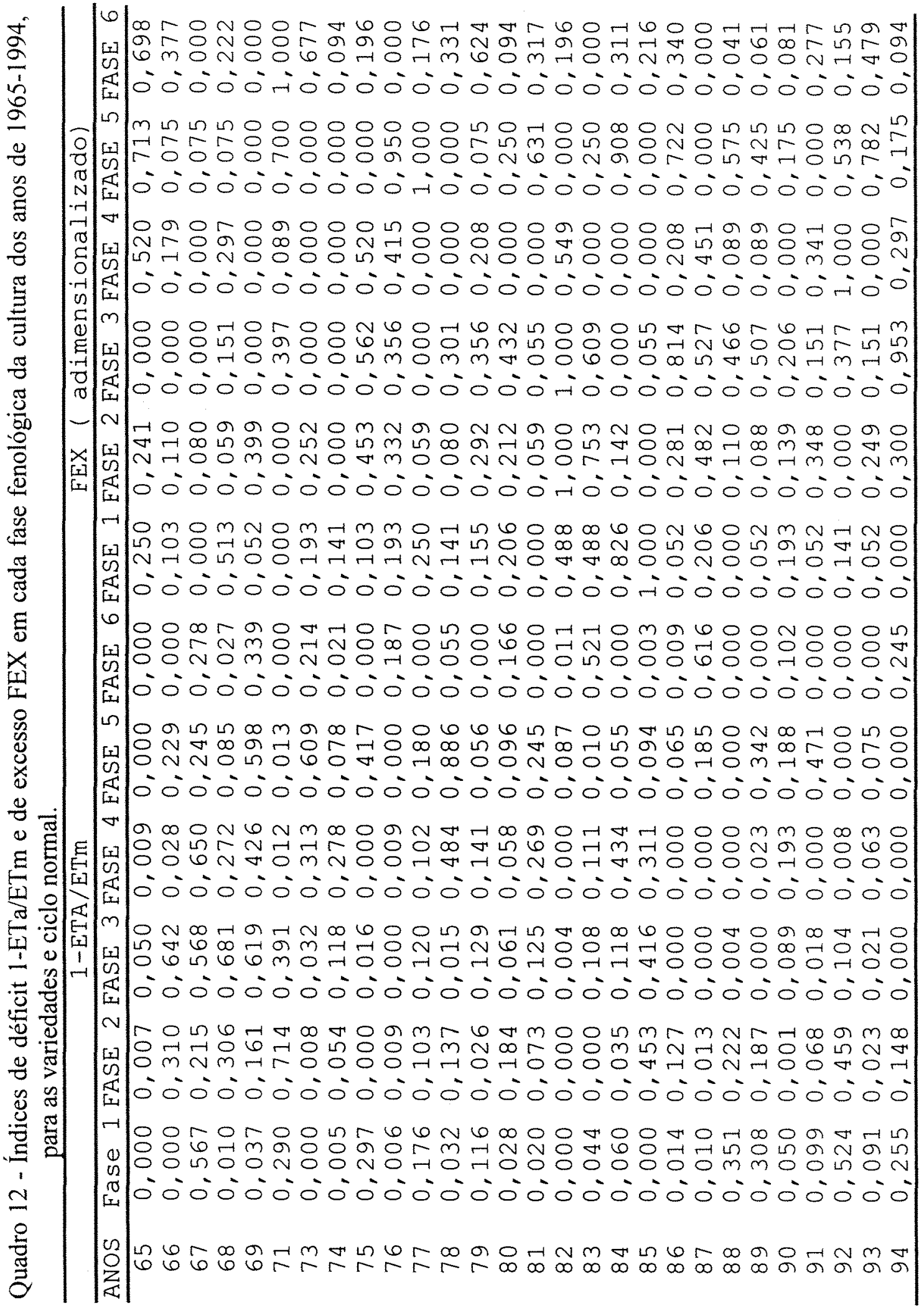




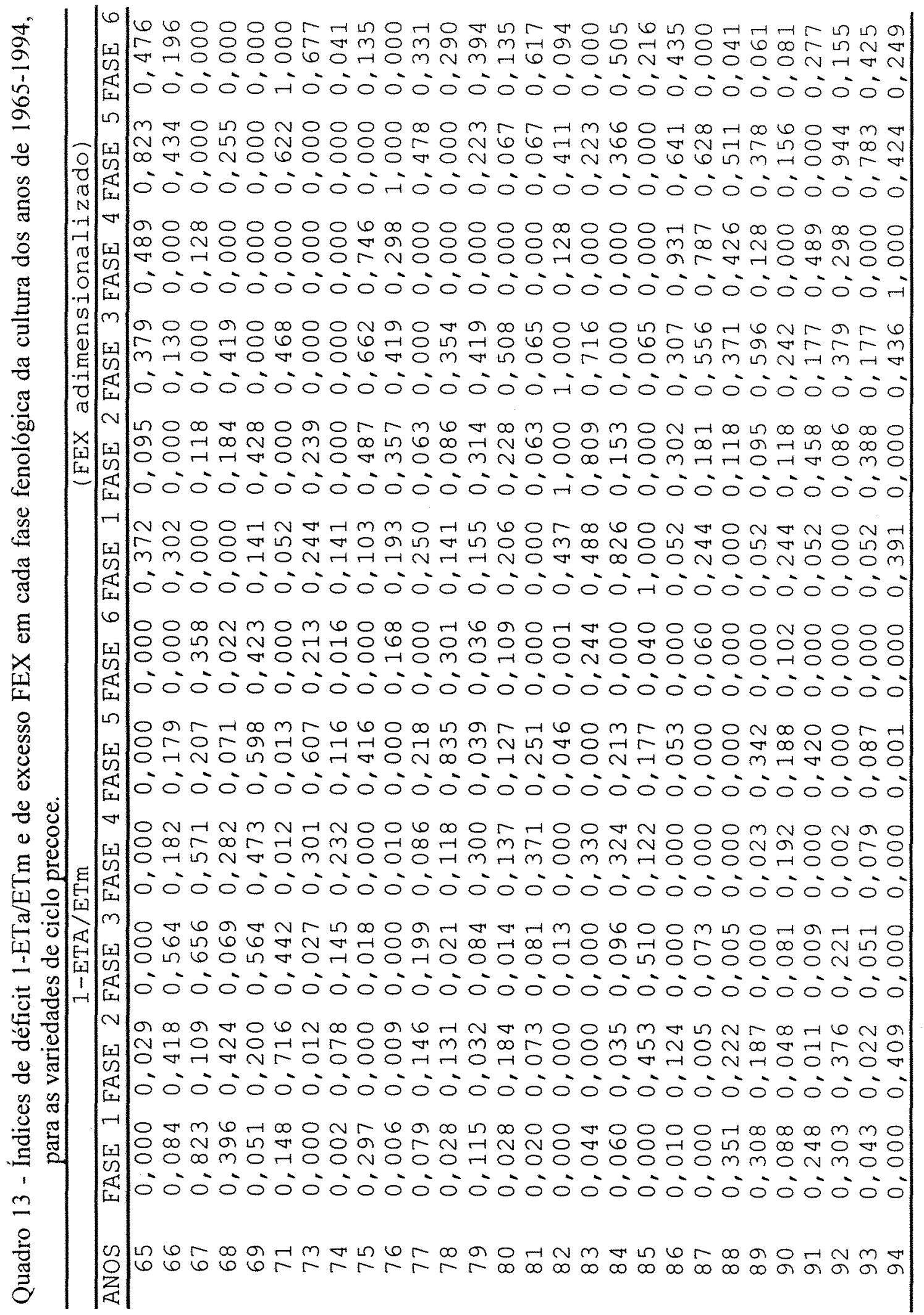




\subsection{Modelos de simulação dos rendimentos}

Com os indices de déficit (1-ETa/ETm) e de excesso de água no solo (FEX adimensionalizados) (Quadros 12 e 13) como variáveis independentes, e os déficits de rendimento relativo (1-ETa/ETm) obtidos como dependentes, desenvolveram-se os modelos para a estimativa dos rendimentos da cultura. Inicialmente ajustaram-se modelos baseados em um índice de stress isoladamente, déficit ou excesso, porém nas seis fases da cultura. Dessa maneira, obteve-se um modelo baseado nos índices de déficit (1-ETa/ETm), e outro nos índices de excesso (FEX). No modelo completo, empregaramse os dois índices de stress, integrando os fenômenos hídricos que ocorrem no solo. Os modelos serão apresentados a seguir.

\subsubsection{Modelo com déficit de água no solo}

O modelo que estima os rendimentos baseado no stress causado pelo déficit hídrico no solo foi desenvolvido com o índice 1-ETa/ETm, nas seis fases da cultura. As estimativas do rendimento, efetuadas com tal modelo, são apresentadas no Quadros 14 e 15 e Figuras 2 (D) e 3 (D). Para as variedades de ciclo normal, os coeficientes obtidos para o modelo que considerou o déficit hídrico 1-ETa/ETm como variável independente, apresentados no Quadro 16, foram de maneira geral discordantes dos resultados obtidos por Robins \& Domingo (1963), Doorenbos \& Kassan (1994) e Meyer et al (1993) e Matzenauer (1994). Segundo os autores citados, a fase de florescimento é a mais sensivel ao déficit hídrico, conforme demonstrado pela dimensão dos coeficientes das equações. O coeficiente da terceira fase fenológica, 1,139, indica para o caso deste estudo, ser esse o período mais sensível ao déficit, isolando-se os efeitos do excesso. Os coeficiente de correlação $\mathrm{R}^{2}$ de 0,728 , como também o índice " $\mathrm{d}$ " proposto por Willmot(1981) de 0,476, e a Figura 2 (D) permitem inferir que os rendimentos (Quadro 14) estão relacionados com o déficit. 
Porém, em alguns anos observaram-se desvios significativos entre as produtividades obtidas e as estimadas pelo modelo, como é o caso dos anos de 1982 e 1986, com desvios de até $6050(143,48 \%)$ e $6116 \mathrm{~kg} / \mathrm{ha}(159,7,1 \%)$. No Quadro 12, pode-se observar que esses anos foram predominantemente úmidos para a cultura No ano de 1982, os excessos foram intensos na terceira e segunda fase fenológica, sendo que os déficits foram nulos na primeira, segunda e quarta, e 0,004,0,087 e 0,0011 na terceira, quinta e sexta. Resultado análogo observou-se no ano de 1986, com excessos intensos na terceira e quinta fases e déficits amenos durante todo o ciclo, com o máximo, 0,127, ocorrendo na segunda fase.

A exemplo das variedades de ciclo normal, o modelo desenvolvido com as de ciclo precoce apresentou coeficientes discordantes dos obtidos por Robins \& Domingo (1963), Doorenbos \& Kassan (1994), Meyer et al (1993) e Matzenauer (1994), principalmente o obtidos para a sexta fase fenológica, que os autores referidos consideram como de pouca sensibilidade ao déficit hídrico. A quarta fase, correspondente ao período do florescimento, é considerada a mais sensível, e mostrou-se mais resistente que a sexta. O coeficiente de correlação $\mathrm{R}^{2}$ de 0,682 e o índice "d" de 0,482 indicam que os rendimentos são influenciados pelo déficit hídrico no solo, porém, em alguns anos, os desvios foram de até 197,2\%. Através dos Quadros 13 e 15 e da Figura 3 (D), observa-se que os desvios entre os rendimentos calculados com o modelo foram menores quando ocorreu predominância de déficits no solo ou poucos excessos. São exemplos de tal comportamento os anos de 1977 e 1981, com desvios de $103(1,4 \%)$ e $132 \mathrm{~kg} / \mathrm{ha}(2,6 \%)$. Os maiores desvios ocorreram quando o solo foi exposto a intensos excessos, como nos anos de 1982, 1986 e 1987, com desvios de 5417 (113,7\%), 4860 $(113,1 \%)$ e $6156 \mathrm{~kg} / \mathrm{ha}(197,2 \%)$ respectivamente. No ano de 1987 , os déficits foram nulos na primeira, segunda, quarta e quinta fases, enquanto que ocorreram excessos em todo o ciclo, com exceção da sexta fase, imediatamente antes do ponto de maturação fisiológica. 
Quadro 14- Rendimento observado (Ya), calculado com o modelo com indice de déficit (1-ETa/ETm), de excesso (FEX), modelo completo (1-ETa/ETm e FEX) e a validação (VALID) para variedades de ciclo normal.

\begin{tabular}{cccccc}
\hline ANO & $\begin{array}{c}\text { Ya } \\
\mathrm{kg} / \mathrm{ha}\end{array}$ & $\begin{array}{c}\text { I-ETa/ETm } \\
\mathrm{kg} / \mathrm{ha}\end{array}$ & $\begin{array}{c}\mathrm{FEX} \\
\mathrm{kg} / \mathrm{ha}\end{array}$ & $\begin{array}{c}\text { COMPLETO } \\
\mathrm{kg} / \mathrm{ha}\end{array}$ & $\begin{array}{c}\text { VALID } \\
\mathrm{kg} / \mathrm{ha}\end{array}$ \\
\hline 75 & 4649 & 5641 & 5502 & 4941 & 5615 \\
76 & 4418 & 8337 & 5054 & 4219 & 3861 \\
77 & 6318 & 5989 & 6150 & 6202 & 5990 \\
78 & 3459 & 1551 & 6984 & 3167 & 1347 \\
79 & 5301 & 6932 & 4413 & 5142 & 4742 \\
80 & 5539 & 6167 & 5697 & 6347 & 7143 \\
81 & 4776 & 5868 & 7290 & 5124 & 5873 \\
82 & 4219 & 10269 & 1584 & 4559 & 6361 \\
83 & 3670 & 1750 & 4308 & 2854 & 1089 \\
84 & 3626 & 4465 & 2959 & 3621 & 3523 \\
86 & 3829 & 9944 & 1464 & 3365 & 2401 \\
87 & 2527 & 2270 & 5767 & 3039 & 4378 \\
88 & 6156 & 6865 & 6150 & 6490 & 6964 \\
90 & 6335 & 5209 & 7392 & 6030 & 7120 \\
91 & 7874 & 7138 & 7580 & 7368 & 6857 \\
92 & 5241 & 2840 & 4938 & 5105 & 3583 \\
93 & 4278 & 8190 & 4322 & 4690 & 5561 \\
94 & 3194 & 4523 & 3510 & 2910 & 2595 \\
\hline
\end{tabular}

Quadro 15 - Rendimento observado (Ya), calculado com o modelo com índice de déficit (1-ETa/ETm), de excesso (FEX), modelo completo (1-ETa/ETm e FEX) e a validação (VALID) para variedades de ciclo precoce

\begin{tabular}{cccccc}
\hline ANO & $\begin{array}{c}\text { Ya } \\
\mathrm{kg} / \mathrm{ha}\end{array}$ & $\begin{array}{c}1-\text { Eta/Etm } \\
\mathrm{kg} / \mathrm{ha}\end{array}$ & $\begin{array}{c}\text { EEX } \\
\mathrm{kg} / \mathrm{ha}\end{array}$ & $\begin{array}{c}\text { COMPLETO } \\
\mathrm{kg} / \mathrm{ha}\end{array}$ & $\begin{array}{c}\text { VALID } \\
\mathrm{kg} / \mathrm{ha}\end{array}$ \\
\hline 75 & 6635 & 7763 & 5946 & 5858 & 4897 \\
76 & 5295 & 7546 & 5676 & 4212 & 3040 \\
77 & 7312 & 7209 & 6578 & 6372 & 5964 \\
78 & 4065 & 2418 & 6252 & 4257 & 6022 \\
79 & 5965 & 5388 & 5019 & 5362 & 4028 \\
80 & 5712 & 4804 & 5399 & 5865 & 5931 \\
81 & 5055 & 5187 & 6174 & 4833 & 4104 \\
82 & 4764 & 10180 & 2860 & 5135 & 6910 \\
83 & 3145 & 2245 & 4998 & 2808 & 1454 \\
84 & 4213 & 5525 & 3196 & 4264 & 6014 \\
85 & 4019 & 2514 & 4102 & 4053 & 4403 \\
86 & 4298 & 9158 & 4812 & 4807 & 5252 \\
87 & 3120 & 9273 & 5148 & 3677 & 4873 \\
88 & 7106 & 6108 & 7185 & 8054 & 8880 \\
89 & 6483 & 5796 & 5098 & 6210 & 5677 \\
90 & 4187 & 5554 & 7825 & 6084 & 6638 \\
91 & 7410 & 7727 & 7802 & 7597 & 7861 \\
93 & 5301 & 8617 & 5219 & 5937 & 6456 \\
94 & 4477 & 6014 & 3286 & 4128 & 3018 \\
\hline
\end{tabular}


Quadro 16 - Coeficientes, valor $F$ da análise de variância, nível de significâncial, e coeficiente de correlação $\mathrm{R}^{2}$ obtidos no desenvolvimento dos modelos completos (1-ETa/ETm e FEX), com índice de déficit (1-ETa/ETm) e indice de excesso (FEX), para normais e precoces

Variedades de ciclo normal.

\begin{tabular}{|c|c|c|c|c|c|c|c|c|c|}
\hline \multirow[b]{3}{*}{ Variáveis } & \multicolumn{9}{|c|}{ Tipo de modelo } \\
\hline & \multicolumn{3}{|c|}{ Completo } & \multicolumn{3}{|c|}{ 1-ETa/ETm } & \multicolumn{3}{|c|}{ FEX } \\
\hline & Coef & $\mathbf{F}$ & Sign & Coef & F & Sign & Coef & F & Sign \\
\hline 1-ETA/ETm $1\left(\mathrm{~d}_{1}\right)$ & 0.255 & 400.1 & ***** & 0.942 & 21.6 & **** & & & \\
\hline 1-ETA/ETm $2\left(\mathrm{~d}_{2}\right)$ & $-0,369$ & 30.3 & ** & 0.197 & 1.6 & 23.1 & & & \\
\hline 1-ETA/ETm $3\left(\mathrm{~d}_{3}\right)$ & 0.063 & 214.2 & $* * * *$ & 1.134 & 11.27 & ** & & & \\
\hline 1-ETA/ETm $4\left(d_{4}\right)$ & 0.826 & 104.1 & $* * * *$ & 0.863 & 5.5 & * & & & \\
\hline 1-ETA/ETm $5\left(d_{5}\right)$ & 0.127 & 40.8 & $* * *$ & 0.356 & 2.1 & 16.9 & & & \\
\hline 1-ETA/ETm $6\left(\mathrm{~d}_{6}\right)$ & 0.586 & 172.0 & **** & 1.097 & 9.1 & ** & & & \\
\hline FEX $1\left(e_{1}\right)$ & -0.105 & 40.9 & $* * *$ & & & & 0.383 & 85.0 & $* * * *$ \\
\hline FEX $2\left(\mathrm{e}_{2}\right)$ & 0.037 & 106.2 & $* * * *$ & & & & -0.013 & 24.9 & $* * *$ \\
\hline $\operatorname{FEX} 3\left(e_{3}\right)$ & 0.432 & 15.0 & $* *$ & & & & 0.575 & 23.7 & $* * *$ \\
\hline $\operatorname{FEX~} 4\left(\mathrm{e}_{4}\right)$ & 0.138 & 1.5 & 26.6 & & & & -0.006 & 0.1 & 73.5 \\
\hline FEX $5\left(e_{5}\right)$ & 0.301 & 52.9 & *** & & & & 0.269 & 12.1 & ** \\
\hline FEX $6\left(e_{6}\right)$ & 0.328 & 5.5 & * & & & & 0.546 & 5.9 & $*$ \\
\hline Modelo & & 98.6 & $* * * *$ & & 8.4 & $* * *$ & & 25.3 & $* * * *$ \\
\hline $\mathbf{R}^{2}$ & & 0.985 & & & 0.782 & & & 0.896 & \\
\hline \multicolumn{10}{|c|}{ Variedades de ciclo precoce } \\
\hline & & omplet & & & TTa/ET & & & FEX & \\
\hline Variáveis & Coef & $\mathbf{F}$ & Sign & Coef & $\mathbf{F}$ & Sign & Coef & $\mathbf{F}$ & Sign \\
\hline 1-ETA/ETm $1\left(d_{1}\right)$ & -0.525 & 98.1 & *** & 0.678 & 11.8 & ** & & & \\
\hline 1-ETA/ETm $2\left(d_{2}\right)$ & 0.123 & 106.8 & $* * * *$ & 0.850 & 12.8 & ** & & & \\
\hline 1-ETA/ETm $3\left(d_{3}\right)$ & 0.575 & 16.3 & ** & 0.279 & 1.9 & 18.5 & & & \\
\hline 1-ETA/ETm $4\left(d_{4}\right)$ & 1.279 & 108.6 & $* * * *$ & 1.123 & 13.0 & ** & & & \\
\hline 1-ETA/ETm $5\left(d_{5}\right)$ & 0.466 & 11.4 & * & 0.059 & 1.4 & 26.2 & & & \\
\hline 1-ETA/ETm $6\left(d_{6}\right)$ & 0.091 & 25.2 & ** & 1.552 & 3.0 & 10.6 & & & \\
\hline FEX $1\left(e_{1}\right)$ & 0.010 & 22.1 & ** & & & & 0.391 & 114.2 & $* * * *$ \\
\hline FEX $2\left(e_{2}\right)$ & 0.039 & 30.4 & *** & & & & -0.213 & 29.3 & $* * * *$ \\
\hline FEX $3\left(e_{3}\right)$ & 0.259 & 10.9 & ** & & & & 0.619 & 18.1 & *** \\
\hline FEX $4\left(e_{4}\right)$ & 0.277 & 22.1 & ** & & & & -0.031 & 2.7 & 12.3 \\
\hline FEX $5\left(e_{5}\right)$ & 0.368 & 15.5 & ** & & & & 0.211 & 8.5 & * \\
\hline FEX $6\left(e_{6}\right)$ & -0.192 & 0,1 & 74.6 & & & & 0.649 & 15.5 & $* *$ \\
\hline Modelo & & 38.9 & $* * * *$ & & 7,3 & & & 31.4 & $* * * *$ \\
\hline $\mathbf{R}^{2}$ & & 0.962 & & & 0.684 & & & 0.910 & \\
\hline
\end{tabular}




\subsubsection{Modelo com excesso de água no solo}

Para o desenvolvimento do modelo baseado no stress hídrico devido ao excesso, empregou-se o índice FEX adimensionalizado, nas seis fases fenológicas da cultura. As estimativas efetuadas com esse modelo são apresentados no Quadros 14 e 15 nas Figuras 2 (E) e 3 (E).
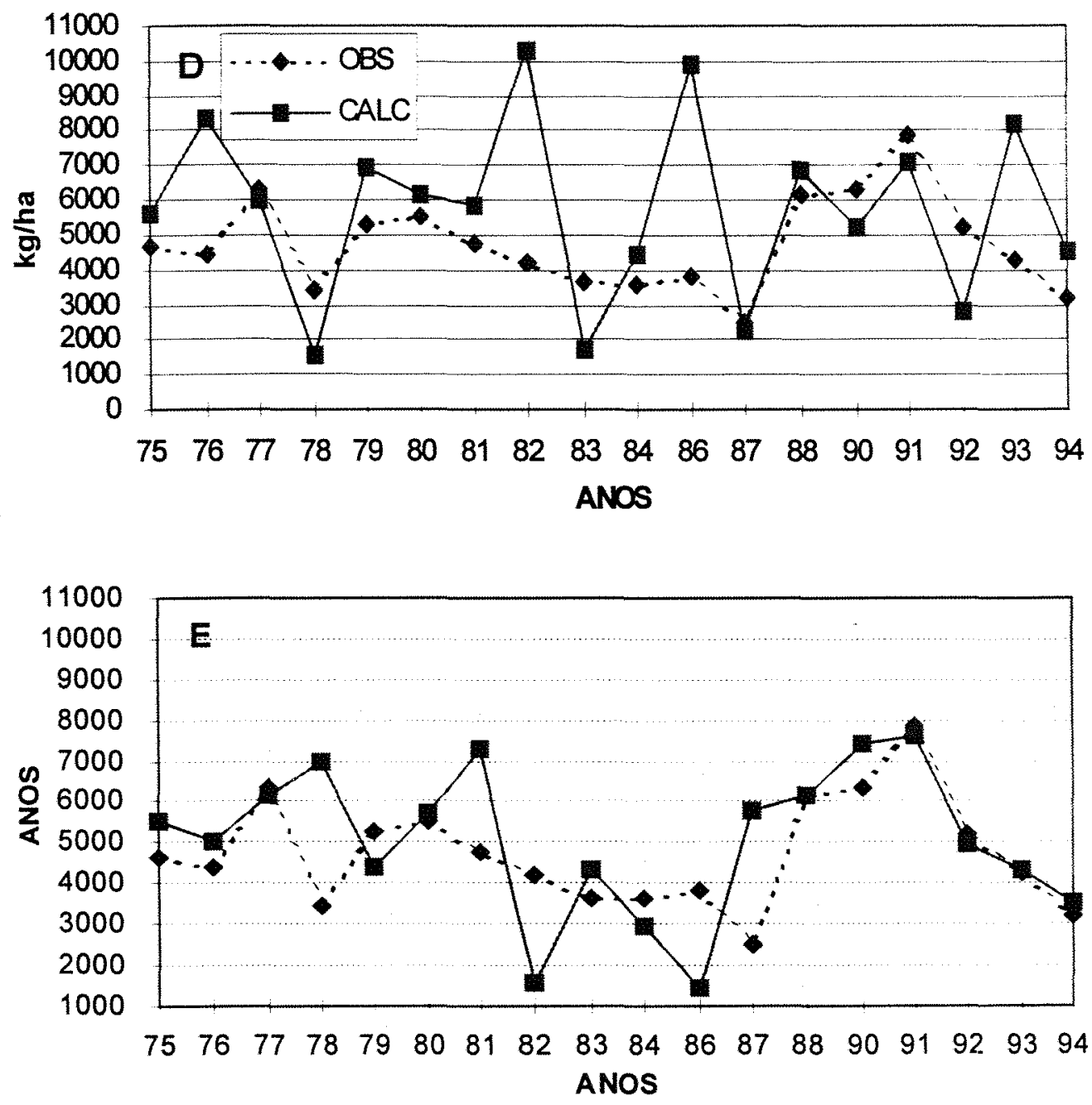

Figura 02 - Rendimento observado e calculado com o modelo obtida com indice de déficit 1-ETa/ETm (D) e FEX (E), para variedades de ciclo normal. 

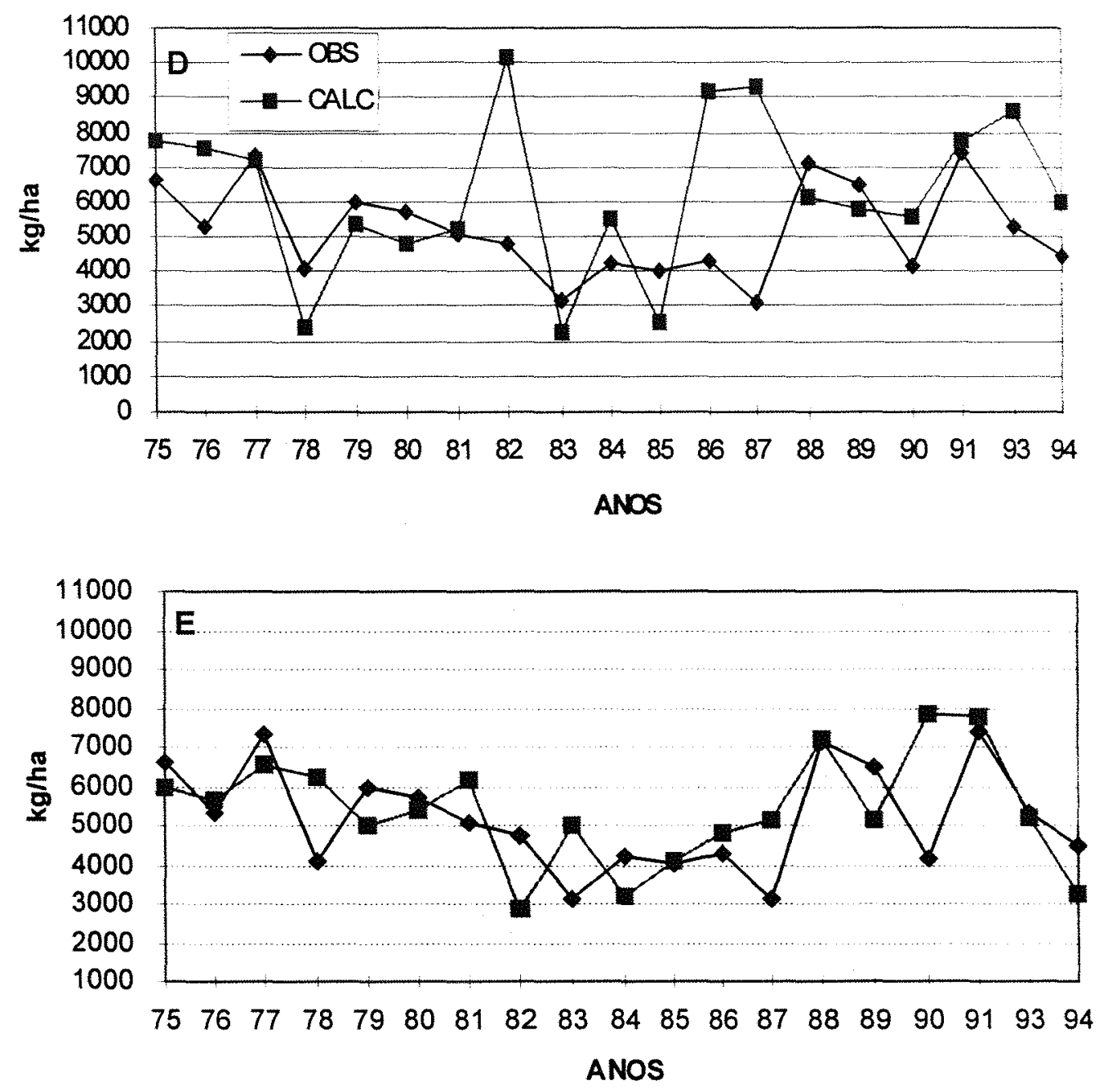

Figura 03 - Rendimento observado e calculado com o modelo obtida com o índice de déficit 1-ETa/ETm (D) e de excesso FEX (E), para as variedade de ciclo precoce.

No entanto, maiores divergências entre os valores estimados e observados foram obtidas com o modelo desenvolvido com os índices de déficit. Tal constatação permite afirmar que exercem maior influência sobre as estimativas de rendimentos da cultura do milho. Entre as variedades de ciclo normal, o desvio máximo de $3525 \mathrm{~kg} / \mathrm{ha},(111,9 \%)$, o coeficiente de correlação $R^{2}$ de 0,896 e o índice "d" de 0,793 indicam que os rendimentos estão condicionados pelos excessos de água no solo. $\mathrm{O}$ desvio máximo citado ocorreu no ano de 1978, ano especialmente seco nas fases mais sensíveis 
da cultura, conforme se observa no Quadro 13. Em anos com predominância de excessos, o modelo subestimou a produtividade, com desvios de $2635 \mathrm{~kg} / \mathrm{ha}(65,2 \%)$ e $2365 \mathrm{~kg} / \mathrm{ha}(61,8 \%)$, nos anos de 1982 e 1986, respectivamente. Por outro lado, quando predominaram os déficits, os desvios foram ainda maiores, $3525 \mathrm{~kg} / \mathrm{ha}(111,9 \%) \mathrm{em}$ 1978, ano especialmente seco. As melhores estimativas ocorreram quando os déficits e os excessos ocorreram em equilíbrio, ou com ligeira predominância de um dos fatores de stress, como nos anos de 1977, 1980 e 1988, com desvios de $169(2,7 \%), 159(2,9 \%)$ e 6 $\mathrm{kg} / \mathrm{ha}(0,1 \%)$. O coeficiente obtido para a terceira fase, imediatamente antes do florescimento (Quadro 16), foi maior do que os obtidos nas outras fases fenológicas, concordando com os dados obtidos por Evans et al (1990) e divergindo das observações de Doorenbos \& Kassan (1994).

Para variedades de ciclo precoce, estimativas apresentadas no Quadro 15 e na Figura 3 (E), obtiveram-se coeficiente de correlação $R^{2}$ de 0,910 e índice "d" de 0,684. Esses resultados indicam que os rendimentos são influenciados pelos excessos de água no solo. As melhores estimativas foram obtidas em anos com predominância de excessos, exceto 1979. Como se pode observar nos Quadros 13 e 15, os anos e 1975, e 1988 são exemplos desse comportamento, com desvios de 689 (10,4\%), e $79 \mathrm{~kg} / \mathrm{ha}$ $(1,1 \%)$, respectivamente. No ano de 1988 , os déficits foram poucos, com excessos entre a segunda e sexta fase fenológica. O modelo estimou com muitos desvios, quando ocorreu predominância de déficits, como em 1978 e 1990, com desvios de 2187 (53,8\%) e $3638 \mathrm{~kg} / \mathrm{ha}(86,9 \%)$. Os coeficientes do modelo (Quadro 16) divergiram dos obtidos pelos autores referidos, principalmente quanto ao da terceira e sexta fases. Segundo tais autores, a terceira e a sexta fases possuem maior e menor sensibilidade ao excesso hídrico respectivamente, diferente do obtido neste trabalho. 


\subsubsection{Modelo completo}

No desenvolvimento do modelo completo, empregaram-se os índices de déficit (1-ETa/ETm)e de excesso (FEX) nas seis fases fenológicas da cultura. Os coeficientes da Equação $31,\left(d_{1}, d_{2}, \ldots, d_{6}\right)$ e $\left(e_{1}, e_{2}, \ldots, e_{6}\right)$, para variedades de ciclo normal e precoce, são apresentados no Quadro 16. As estimativas efetuadas com o modelo completo são apresentadas nos Quadros 14 e 15 e na Figura 4.

Os modelos considerando o excesso ou o déficit hídrico isoladamente mostraramse ineficientes para estimar os rendimentos da cultura do milho. Quando se agruparam em um só modelo os dois índices de stress, as estimativas foram melhores, com um coeficiente de correlação $\mathrm{R}^{2} \mathrm{e}$ índice " $\mathrm{d}$ " superiores a 0,90 .

No Quadro 14 e na Figura $4(\mathrm{~N})$, observa-se que entre as variedades der ciclo normal, nos anos com predominância de excessos, 1982 e 1986, os desvios foram de 340 $(8,1 \%)$ e $464 \mathrm{~kg} / \mathrm{ha}(12,1 \%)$ respectivamente. Nos que predominaram os déficits, $1978 \mathrm{e}$ 1987, os desvios foram de 291 (8,4\%)e $512 \mathrm{~kg} / \mathrm{ha}(20,2 \%)$ respectivamente. Para os anos com equilibrio entre os índices, 1981, 1984 e 1990, os desvios foram de 348 (7,3\%), 5 $(0,1 \%)$ e $506 \mathrm{~kg} / \mathrm{ha}(6,4 \%)$, respectivamente. No ajuste do modelo, obteve-se coeficiente de correlação de 0,986 , com índice $\mathrm{d}$ de 0,976 , valores superiores aos obtidos quando empregou-se apenas um índice de stress separadamente.

Os coeficientes obtidos para as variáveis referentes ao déficit hídrico foram: $0,255,-0,369,0.060,0.826,0.127$ e 0.586 para as seis fases fenológicas da cultura, respectivamente. Tais valores se aproximam dos obtidos por Matzenauer (1994), quando agrupou dados de quatro locais diferentes. $O$ autor obteve os seguintes resultados: $-0,221$, $0,173,0,827$ e 0,200 , para 4 fases fenológicas da cultura, respectivamente, sendo que a primeira se inicia na emergência e a terceira corresponde ao florescimento.

O coeficiente para o déficit obtido com a regressão para a fase de florescimento foi maior que a das outras fases, e concordância com Robins \& Domingo (1963), Doorenbos \& Kassan (1994), Meyer et al (1993) e Matzenauer (1994).

Os coeficientes para as variáveis referentes ao excesso hídrico convergem para os resultados obtidos por Evans et al (1990), Muktar et al (1990) e Howell et al (1976), 
sendo o correspondente à terceira fase maior do que o obtido para as outras, indicando maior sensibilidade a esse stress. Nas fases após o florescimento, a ordem de magnitude foi inversa à obtida pelos autores citados.

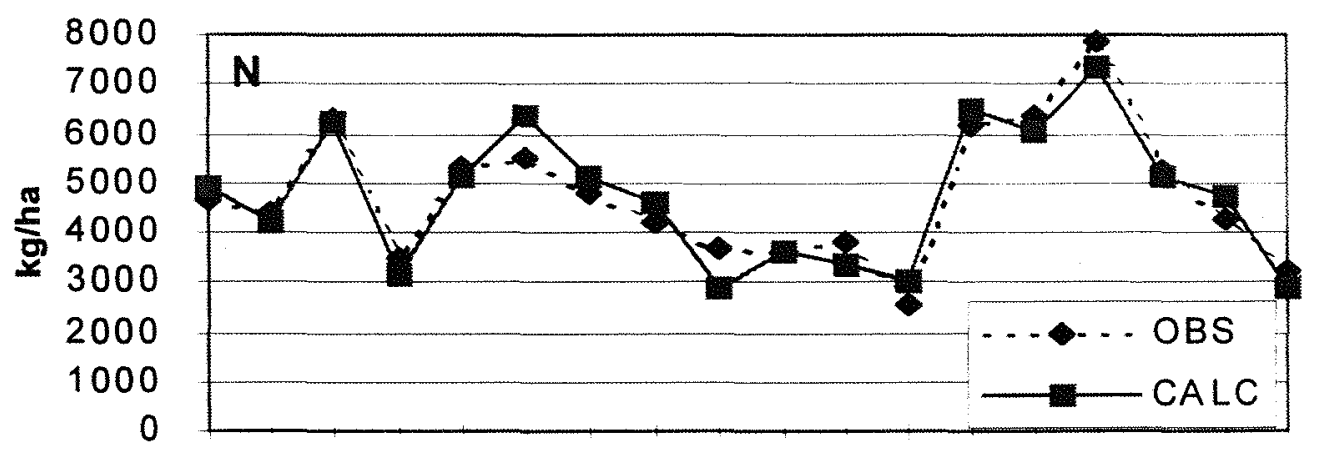

$\begin{array}{llllllllllllllllll}75 & 76 & 77 & 78 & 79 & 80 & 81 & 82 & 83 & 84 & 86 & 87 & 88 & 90 & 91 & 92 & 93 & 94\end{array}$

ANOS

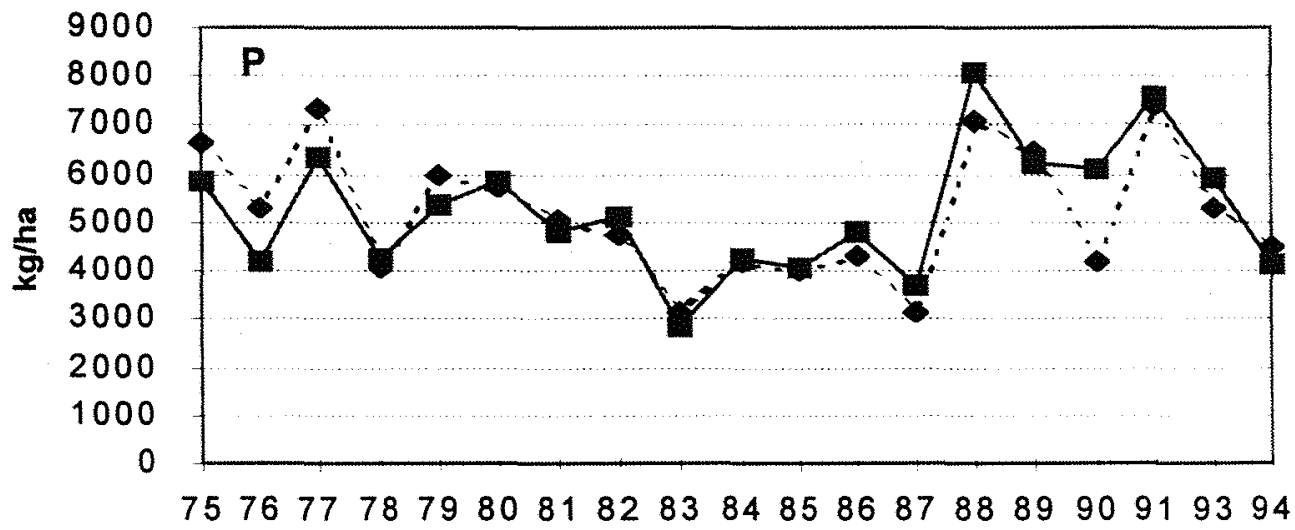

ANOS

Figura 04 Rendimento observado e calculado com o modelo completo, 1ETa/ETm e FEX nas 6 fases fenológicas da cultura para as variedades de ciclo normal $(\mathrm{N})$ e precoces $(\mathrm{P})$, no período 1975 1994.

O modelo ajustado para as variedades de ciclo precoce, cujas estimativas estão no Quadro 15 e na Figura 4 (P), apresentou desvios de $372(7,8 \%)$ e $509 \mathrm{~kg} / \mathrm{ha}(11,8 \%)$ para os rendimentos dos anos de 1982 e 1986, respectivamente, predominantemente úmidos para a cultura. Nos anos com equilíbrio entre excessos e déficits, 1983 e 1993, os 
desvios foram de $338(10,7 \%)$ e $636 \mathrm{~kg} / \mathrm{ha}(12,0 \%)$ respectivamente. Nos anos que tiveram predominância de déficits, 1979, 1980 e 1990, os desvios foram de $603(10,1 \%)$, $152(2,7 \%)$ e $1898 \mathrm{~kg} / \mathrm{ha}(45,3 \%)$ respectivamente. No ajuste do modelo, obteve-se coeficiente de correlação de 0,962, com índice d de 0,926, também superiores aos obtidos quando empregou-se apenas um índice de stress separadamente.

Os coeficientes obtidos são apresentados no Quadro 16, os quais, de maneira geral, convergem para os relatados por Matzenauer (1994), Doorenbos \& Kassan (1994) e Stewart et al (1975). Como se pode observar, o maior coeficiente encontrado, 1,279, para a fase de florescimento, comprova ser esta a mais sensivel ao déficit hídrico. Quanto aos coeficientes dos índices de excesso, eles divergem dos obtidos por Evans et al (1990), Muktar et al (1990) e Howell et al (1976), os quais relatam que a terceira fase, no final do período vegetativo apresenta maior sensibilidade aos excessos de água no solo.

Quanto ao coeficiente negativo, obtido na segunda fase, para as variedades de ciclo normal, e na primeira, para as precoces, que corresponde ao período de estabelecimento da cultura, o qual se estende desde a semeadura até 32 dias após, concorda com o obtido por Meyer et al (1993) e Matzenauer (1994), sugerindo que os déficits ocorridos durante tal período propiciam aumentos de rendimentos. Stewart et al (1975), obtiveram maiores coeficientes na fase de florescimento, quando a fase vegetativa foi suprida adequadamente com água. Quando se impuseram déficits na fase vegetativa, os coeficientes para o florescimento foram menores. Consideraram os autores que a cultura se condiciona a uma situação de stress, diminuindo os efeitos nas fases seguintes. Meyer et al (1993) obtiveram coeficientes negativos na fase vegetativa, período que antecede o do florescimento, creditando-se esse fato ao maior aprofundamento das raízes em busca de água. $\mathrm{Na}$ fase seguinte, a mais crítica para a cultura, a planta explora maior volume de solo, aproveitando melhor a umidade disponível e diminuindo as perdas de rendimento devidas ao déficit de água.

A discordância existente entre os coeficientes obtidos neste trabalho e os obtidos pelos autores citados anteriormente pode ser atribuída a diferenças entre o clima em que foram desenvolvidas como também à metodologia utilizada, pois, neste estudo, as 
estimativas de evapotranspiração real da cultura não foram influenciadas pelos excessos de água no solo; o kc empregado não foi alterado pelo índice de área foliar, que segundo Begg \& Turner (1976), Espinoza (1982) e Eck (1986), é afetado pelo déficit hídrico.

O emprego dos dois tipos de stress integrou os fenômenos hídricos que ocorrem no solo e influenciam o desenvolvimento da cultura durante seu ciclo. Os índices de excesso considerados nas 6 fases fenológicas da cultura integram os prejuízo advindos do excesso de água no solo sobre o rendimento da cultura, como a diminuição da taxa de oxigênio (Wesseling, 1974), as perdas de nutrientes (Ritter \& Beer 1969) a diminuição da fotossintese e o aumento da respiração (Woudt \& Hagan, 1957) e (Letey et al 1962). Os danos causados pelo déficit de água no solo foram integrados pelo déficit de evapotranspiração relativa 1-ETa/ETm, expressando os efeitos do fechamento dos estômatos (Slatier, 1967) e a diminuição da produção de fotossintatos, (Boyer \& Mc Pherson, 1975), e a dos rendimentos (Hanks \& Rasmussem 1982). O efeito combinado dos índices de stress confirma as observações de Woudt \& Hagan (1957), Pereira (1982), como também os resultados obtidos por Brunini et al (1982) e Camargo (1988) com soja, que relatam que ocorreu melhor performance quando incluíram um "fator de excedente" em modelos de estimativa dos rendimentos. Brunini et al (1982) relatam que o modelo estimou particularmente bem em anos com precipitação elevada. Radulovich (1987 e 1990), com arroz, feijão e milho, obteve melhores correlações com modelos que contemplavam os dois fatores de stress hídrico (déficit e excesso) do que quando empregou apenas o fator de déficit isoladamente.

\subsubsection{1 - Validação do modelo completo}

Os resultados da validação cruzada, empregada neste trabalho, estão nos Quadros 14 e 15 e na Figura 5. O índice "d" de 0,800 e 0,696, e coeficientes de correlação $r^{2}$ de 0,493 e 0,246 , para variedades de ciclo normal e precoce, respectivamente, informam o nível de acerto das estimativas obtidas com o modelo. $\mathrm{O}$ ajuste do modelo completo e sua validação apresentaram índices estatísticos aceitáveis, no entanto quando se empregou o modelo em dados fora do período utilizado no seu desenvolvimento, houve maior divergência entre os dados observados e os calculados. Ocorreram casos de 
estimativa de rendimento abaixo de zero, o que resultaria em ganhos com irrigação superdimensionados, iguais ao potencial. $\mathrm{O}$ ajuste do modelo completo e os resultados obtidos nos anos anteriores sugerem que o clima que ocorreu no período do desenvolvimento do modelo, 1975-1994, foi mais propício para a cultura do que o
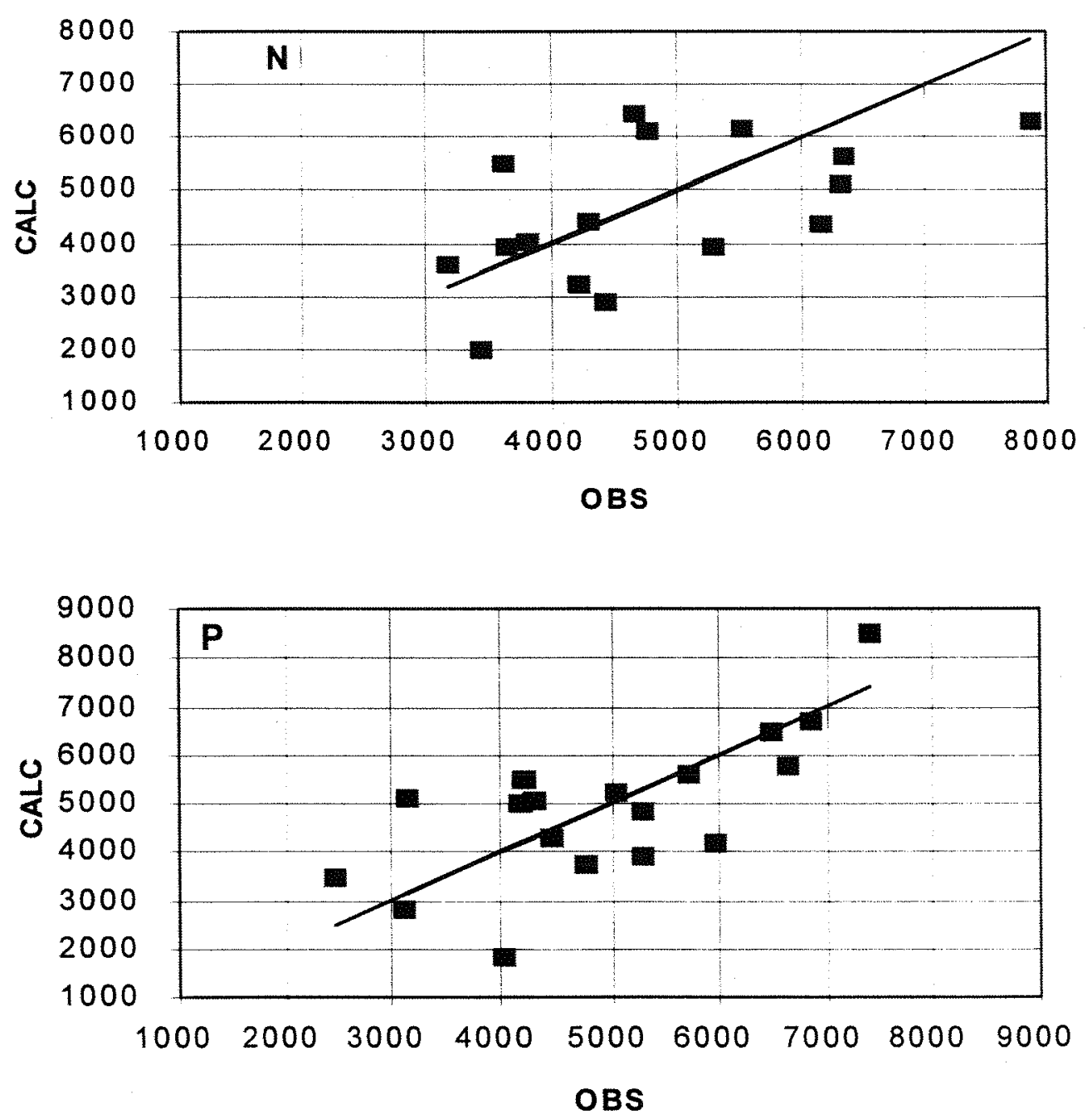

Figura 05 - Rendimento observado (OBS)e calculado através de validação cruzada (CALC) no período de 1975 - 1994 para variedades de ciclo normal (N) e precoce (P). 
anterior, 1965-1974. Ressalta-se também que no período anterior as datas de plantio foram baseadas na média do ocorrido entre 1975-1994, e que a fenologia foi estimada através da média dos somatórios de graus-dia observados no mesmo período.

\subsection{O efeito da irrigação sobre os rendimentos (efeito do déficit hídrico)}

Os ganhos de rendimento, advindos da irrigação e simulados com o modelo completo, são apresentados nos Quadros 17 e 18 e na Figura 6. Ressalta-se que os ganhos advindos da aplicação da irrigação significam também o efeito do déficit hídrico sobre o rendimento da cultura.

Para as variedades de ciclo normal, os ganhos decorrentes da irrigação (Quadro 17 e Figura $6(\mathrm{~N})$ ), simulados através do modelo completo, que contém os dois fatores de stress hídrico, 1-ETa/ETm e FEX, variaram desde quantias insignificantes, em anos com pouco déficit, $182 \mathrm{~kg} / \mathrm{ha}(1,7 \%)$ no ano de 1986 , até $10765 \mathrm{~kg} / \mathrm{ha}(85,8 \%) \mathrm{em} 1978$. Os acréscimos de rendimento foram pequenos em duas situações, quando a freqüência de excessos foi alta, ou quando os déficits foram poucos. No primeiro caso, mesmo que tenha ocorrido baixo rendimento quando não irrigado, a presença de excessos em fases sensíveis, diminuiu a possibilidade de acréscimo com irrigação. São exemplos desse comportamento os anos de 1982 e 1986, cujos resultados sem irrigação foram de 4559 e $3365 \mathrm{~kg} /$ ha, porém com a irrigação simulada, os acréscimos foram de $194(1,8 \%)$ e 182 $\mathrm{kg} / \mathrm{ha}(1,7 \%)$. A segunda possibilidade ocorreu quando os rendimentos não foram baixos, nos anos de 1988 e 1991, nos quais, a partir de 6490 e 7368 kg/ha sem irrigação, simularam-se ganhos de $988(8,9 \%)$ e $871 \mathrm{~kg} / \mathrm{ha}(8,6 \%)$, além do fato de o rendimento obtido sem irrigação já estar próximo do potencial, 11041 e $10123 \mathrm{~kg} / \mathrm{ha}$ respectivamente.

Com as variedades de ciclo precoce, Quadro 18 e Figura $6(\mathrm{P})$, os resultados foram diferentes dos obtidos com as de ciclo normal. Os Ganhos com irrigação foram menores que $100 \mathrm{~kg} / \mathrm{ha}$ em 5 anos, 1988, 1989 e 1992. Estes apresentaram 
predominância de excessos, conforme se pode observar no Quadro 13. Os maiores ganhos ocorreram nos anos que apresentaram maiores déficits, porém sem a ocorrência de excessos. Como ocorreu com as variedades de ciclo normal, os ganhos foram pequenos em duas situações. A primeira ocorreu quando os excessos foram altos, anos de 1986 e 1987, nos quais, a partir de rendimentos observados de 4801 e $3677 \mathrm{~kg} / \mathrm{ha}$, obtiveram-se ganhos de $340(3,3 \%)$ e $503 \mathrm{~kg} / \mathrm{ha}(4,8 \%)$, respectivamente. A segunda possibilidade ocorreu quando os déficits foram poucos, a exemplo dos anos de 1989 e 1991. Nesses anos, observaram-se rendimentos de 6210 e $7597 \mathrm{~kg} / \mathrm{ha}$, obtendo-se ganhos de $52(0,5 \%)$ e $2120 \mathrm{~kg} / \mathrm{ha}(21,8 \%)$, respectivamente. Ressalta-se que os rendimentos observados nesses anos estão próximos do potencial, 9896 e 9717 kg/ha, respectivamente.

Nos Quadros 17 e 18, observa-se que, em média, os acréscimos de rendimento foram de 2626 e $3227 \mathrm{~kg} / \mathrm{h}$ p para variedades de ciclo normal e precoce, respectivamente, dentro da faixa citada por Rhoads \& Bennet (1990), os quais sugerem que os ganhos com irrigação estão entre 2500 e $3800 \mathrm{~kg} / \mathrm{ha}$, superiores aos resultados obtidos por Espinoza et al (1980), que obteve ganhos que variaram entre $1239 \mathrm{~kg} / \mathrm{ha}$ para "veranico" de 14 a 16 dias e $2554 \mathrm{~kg} / \mathrm{ha}$ quando esse período se estendeu por 41 dias, com uma variedade (entre 3 testadas) considerada resistente à seca. Os ganhos máximos com irrigação, 10765 e $11271 \mathrm{~kg} / \mathrm{ha}$ para variedades de ciclo normal e precoce, respectivamente, estão próximos dos relatados por Cassel et al (1985), $2450 \mathrm{~kg} / \mathrm{ha} \mathrm{em}$ ano úmido (precipitação de $464 \mathrm{~mm}$ ) e 7530 e $7060 \mathrm{~kg} / \mathrm{ha}$ em anos que consideraram secos (precipitações de 262 e $220 \mathrm{~mm}$ respectivamente).

Os rendimentos mínimos estimados com a simulação da irrigação, 3547 e 4181 $\mathrm{kg}$ /ha, para variedades de ciclo normal e precoce, respectivamente, estão abaixo dos considerados bons por Doorenbos \& Kassan (1994) para clima subtropical, com temperatura média superior a $20^{\circ} \mathrm{C}, 6000 \mathrm{~kg} / \mathrm{ha}$. Quanto ao máximo, 12549 e 11271 $\mathrm{kg} / \mathrm{ha}$ estão acima dos sugeridos pelos autores anteriormente citados, $9000 \mathrm{~kg} / \mathrm{ha}$, e inferiores aos esperados por Rhoads \& Bennet (1990), entre 11000 e $15000 \mathrm{~kg} / \mathrm{ha}$, valores que superam a média dos rendimentos potenciais calculados para Urussanga (SC) neste trabalho, 10643 e $10356 \mathrm{~kg} /$ ha para variedades de ciclo normal e precoce, 
respectivamente. Essa diferença entre os rendimentos potenciais reflete as diferentes condições ecológicas e os recursos genéticos empregados. Porém, quando se considera a média, obteve-se, neste trabalho, 7788 e $8069 \mathrm{~kg} / \mathrm{ha}, 3,7 \%$ e 7,1\% superiores a 7500 $\mathrm{kg} / \mathrm{ha}$, sugerido por Doorenbos \& Kassan (1994), e pouco inferiores, 2,7 e 0,9\%, a expectativa média de Empresa Brasileira de Pesquisa Agropecuária (1993), que é de $8000 \mathrm{~kg} / \mathrm{ha}$.

\section{5. - O efeito do excesso hídrico sobre os rendimentos}

Os efeitos do excesso hídrico são apresentados nos Quadros 17 e 18, e foram estimados conforme metodologia descrita no item 3.11 deste trabalho. Os menores valores ocorreram em anos com predominância absoluta de déficits, 1974 e 1985, para as variedades de ciclo normal, e 1973 e 1981, para precoces, como pode também ser observado nos Quadros 12 e 13. Nesses anos, os ganhos advindos da simulação da irrigação foram máximos, ou seja, atingiu-se o rendimento potencial. Entre as precoces, os maiores efeitos do excesso ocorreram em anos com pouco déficit, 1987, 1976 e 1982 . Neles, os decréscimos de rendimento foram de $6326(60,2 \%), 6064(57,5 \%)$ e 4831 $\mathrm{kg} / \mathrm{ha}(47,1 \%)$, respectivamente. Para as variedades de ciclo normal, as maiores diminuições de rendimento, devidas aos excessos, ocorreram nos anos de 1986, com decréscimo de $7154 \mathrm{~kg} / \mathrm{ha}(70,3 \%)$ e 1982 , com $6721 \mathrm{~kg} / \mathrm{ha}(62,78 \%)$. No Quadro 18 , podem-se observar os efeitos médios do déficit e do excesso sobre o rendimento da cultura. Para as normais, o efeito médio do excesso hídrico no rendimento do cultura foi de $2992 \mathrm{~kg} / \mathrm{ha}(29,4 \%)$, superior em $6 \%$ ao do déficit, $2626 \mathrm{~kg} / \mathrm{ha}(23,7 \%)$. Entre as precoces, $2467 \mathrm{~kg} / \mathrm{ha}(23,9 \%)$, efeito menor do que o do déficit, $3227 \mathrm{~kg} / \mathrm{ha}(29,7 \%)$. Tal constatação sugere que, nem sempre, a irrigação fará com que a cultura tenha uma performance equivalente ao rendimento potencial, havendo incertezas com relação aos resultados possíveis, que dependerão da intensidade e da distribuição das chuvas através do ciclo da cultura, confirmando as observações de Camp et al (1990). 

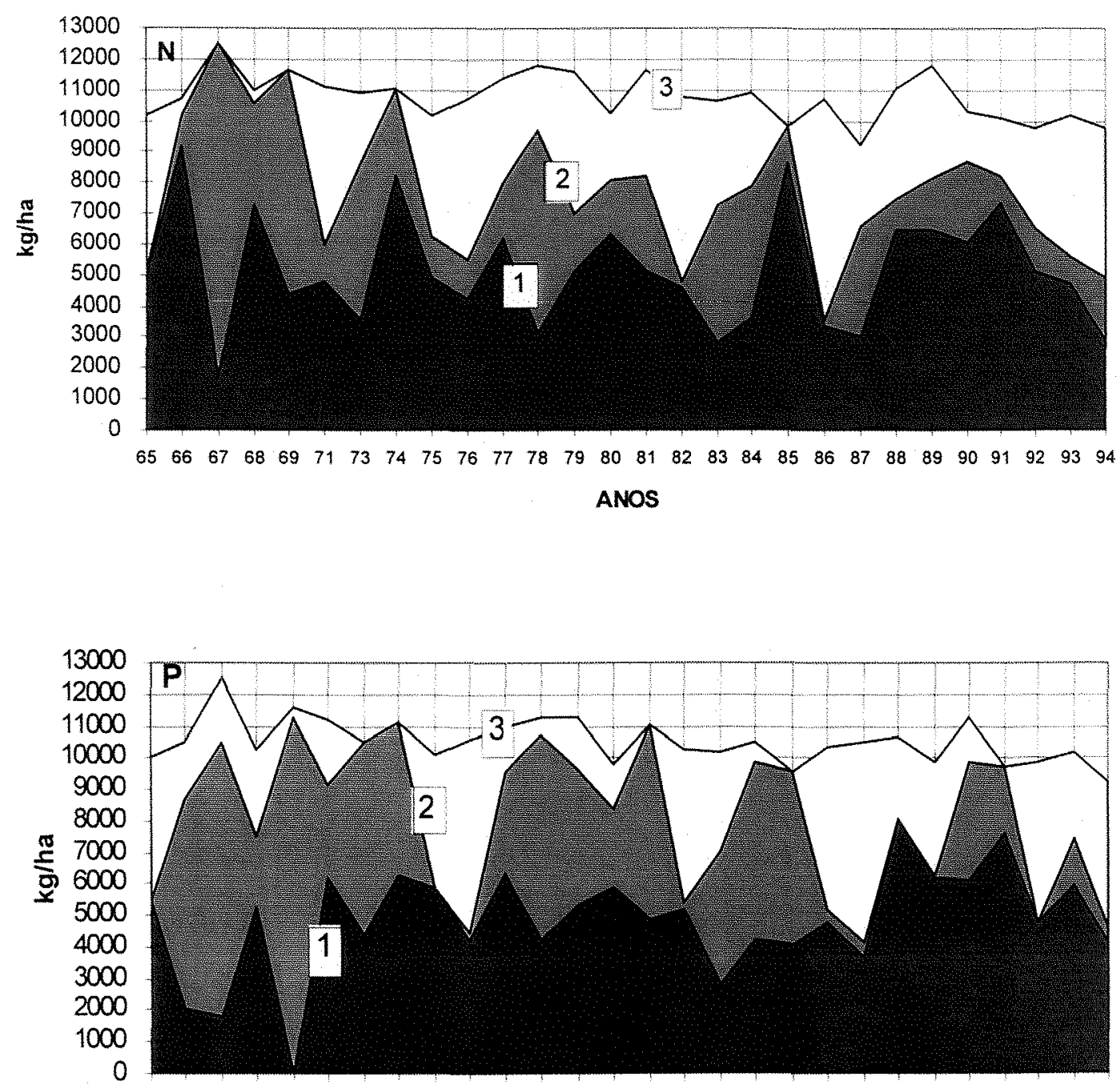

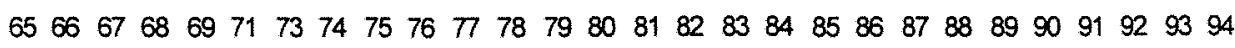

ANOS

Figura 06 - Rendimento com déficit e excesso (1), rendimento sem o efeito do déficit (2), rendimento sem o efeito do excesso e do déficit (3), para variedades de ciclo normal $(\mathrm{N})$ e precoce $(\mathrm{P})$. 
Quadro 17 - Rendimento potencial (Ym), observado (Ya), calculado com o modelo completo (CALC), com irrigação simulada (IRR), ganho com a irrigação simulada (GANHO) e diminuição do rendimento devido ao efeito do excesso (EXCESSO), para as variedades de ciclo normal.

\begin{tabular}{|c|c|c|c|c|c|c|}
\hline ANO & $\begin{array}{c}\mathrm{Ym} \\
\mathrm{kg} / \mathrm{ha}\end{array}$ & $\begin{array}{c}\text { OBS } \\
\mathrm{kg} / \mathrm{ha}\end{array}$ & $\begin{array}{l}\text { CALC } \\
\mathrm{kg} / \mathrm{ha}\end{array}$ & $\begin{array}{c}\text { IRR } \\
\mathrm{kg} / \mathrm{ha}\end{array}$ & $\begin{array}{c}\text { GANHO } \\
\mathrm{kg} / \mathrm{ha}\end{array}$ & $\begin{array}{c}\text { EXCESSO } \\
\mathrm{kg} / \mathrm{ha}\end{array}$ \\
\hline 65 & 10186 & & 5022 & 5129 & 108 & 5057 \\
\hline 66 & 10714 & & 9178 & 10173 & 995 & 541 \\
\hline 67 & 12549 & & 1784 & 12549 & 10765 & 0 \\
\hline 68 & 10982 & & 7304 & 10570 & 3265 & 412 \\
\hline 69 & 11640 & & 4359 & 11640 & 7281 & 0 \\
\hline 71 & 11145 & & 4790 & 6018 & 1228 & 5127 \\
\hline 73 & 10882 & & 3568 & 8608 & 5040 & 2274 \\
\hline 74 & 11060 & & 8219 & 11060 & 2841 & 0 \\
\hline 75 & 10204 & 4649 & 4941 & 6265 & 1324 & 3939 \\
\hline 76 & 10704 & 4418 & 4219 & 5493 & 1274 & 5210 \\
\hline 77 & 11402 & 6318 & 6202 & 8018 & 1817 & 3384 \\
\hline 78 & 11776 & 3459 & 3167 & 9695 & 6528 & 2080 \\
\hline 79 & 11618 & 5301 & 5142 & 7019 & 1878 & 4599 \\
\hline 80 & 10242 & 5539 & 6347 & 8073 & 1726 & 2169 \\
\hline 81 & 11645 & 4776 & 5124 & 8229 & 3105 & 3416 \\
\hline 82 & 10788 & 4219 & 4559 & 4752 & 194 & 6035 \\
\hline 83 & 10638 & 3670 & 2854 & 7280 & 4426 & 3358 \\
\hline 84 & 10945 & 3626 & 3621 & 7871 & 4250 & 3074 \\
\hline 85 & 9818 & & 8644 & 9818 & 1174 & 0 \\
\hline 86 & 10705 & 3829 & 3365 & 3547 & 182 & 7158 \\
\hline 87 & 9205 & 2527 & 3039 & 6602 & 3563 & 2602 \\
\hline 88 & 11041 & 6156 & 6490 & 7478 & 988 & 3563 \\
\hline 89 & 11788 & & 6490 & 8154 & 1664 & 3635 \\
\hline 90 & 10294 & 6335 & 6030 & 8721 & 2691 & 1573 \\
\hline 91 & 10123 & 7874 & 7368 & 8240 & 871 & 1883 \\
\hline 92 & 9767 & 5241 & 5105 & 6538 & 1433 & 3229 \\
\hline 93 & 10181 & 4278 & 4690 & 5564 & 874 & 4617 \\
\hline 94 & 9781 & 3194 & 2910 & 4948 & 2038 & 4833 \\
\hline MÉDIA & 10779 & 4745 & 5162 & 7788 & 2626 & 2992 \\
\hline
\end{tabular}


Quadro 18 -Rendimento potencial (Ym), observado (Ya), calculado com o modelo completo (CALC), com irrigação simulada (IRR), ganho com a irrigação simulada (GANHO) e diminuição do rendimento devido ao efeito do excesso (EXCESSO), para as variedades de ciclo precoce.

\begin{tabular}{|c|c|c|c|c|c|c|}
\hline ANO & $\begin{array}{c}\mathrm{Ym} \\
\mathrm{kg} / \mathrm{ha}\end{array}$ & $\begin{array}{c}\mathrm{Ya} \\
\mathrm{kg} / \mathrm{ha}\end{array}$ & $\begin{array}{l}\text { CALC } \\
\mathrm{kg} / \mathrm{ha}\end{array}$ & $\begin{array}{l}\text { IRR } \\
\mathrm{kg} / \mathrm{ha}\end{array}$ & $\begin{array}{c}\text { GANHO } \\
\mathrm{kg} / \mathrm{ha}\end{array}$ & $\begin{array}{c}\text { EXCESSO } \\
\mathrm{kg} / \mathrm{ha}\end{array}$ \\
\hline 65 & 10045 & & 5465 & 5502 & 36 & 4544 \\
\hline 66 & 10456 & & 2018 & 8669 & 6651 & 1787 \\
\hline 67 & 12551 & & 1773 & 10514 & 8741 & 2037 \\
\hline 68 & 10248 & & 5232 & 7497 & 2265 & 2750 \\
\hline 69 & 11567 & & 0 & 11271 & 11271 & 296 \\
\hline 71 & 11209 & & 6216 & 9187 & 2971 & 2022 \\
\hline 73 & 10522 & & 4357 & 10522 & 6165 & 0 \\
\hline 74 & 11128 & & 6257 & 11128 & 4871 & 0 \\
\hline 75 & 10099 & 6635 & 5858 & 5899 & 41 & 4200 \\
\hline 76 & 10540 & 5295 & 4212 & 4475 & 264 & 6064 \\
\hline 77 & 10969 & 7312 & 6372 & 9554 & 3182 & 1415 \\
\hline 78 & 11256 & 4065 & 4257 & 10750 & 6492 & 507 \\
\hline 79 & 11309 & 5965 & 5362 & 9664 & 4303 & 1645 \\
\hline 80 & 9797 & 5712 & 5865 & 8371 & 2507 & 1425 \\
\hline 81 & 11046 & 5055 & 4833 & 11046 & 6213 & 0 \\
\hline 82 & 10264 & 4764 & 5135 & 5433 & 298 & 4831 \\
\hline 83 & 10187 & 3145 & 2808 & 7026 & 4218 & 3161 \\
\hline 84 & 10502 & 4213 & 4264 & 9860 & 5597 & 642 \\
\hline 85 & 9574 & 4019 & 4053 & 9574 & 5521 & 0 \\
\hline 86 & 10353 & 4298 & 4807 & 5147 & 340 & 5207 \\
\hline 87 & 10507 & 3120 & 3677 & 4181 & 503 & 6326 \\
\hline 88 & 10667 & 7106 & 8054 & 8054 & 0 & 2613 \\
\hline 89 & 9896 & 6483 & 6210 & 6262 & 52 & 3634 \\
\hline 90 & 11275 & 4187 & 6084 & 9872 & 3788 & 1402 \\
\hline 91 & 9717 & 7410 & 7597 & 9717 & 2120 & 0 \\
\hline 92 & 9884 & 2468 & 4756 & 4756 & 0 & 5128 \\
\hline 93 & 10215 & 5301 & 5937 & 7413 & 1476 & 2802 \\
\hline 94 & 9228 & 4477 & 4128 & 4600 & 472 & 4628 \\
\hline MEDIA & 10585 & 5082 & 4869 & 8198 & 3329 & 2387 \\
\hline
\end{tabular}




\subsection{Tempo de retorno dos ganhos com a irrigação simulada}

Os acréscimos de rendimento de grãos, advindos da simulação da irrigação, são apresentados nos Quadros 17 e 18 e na Figura 6. Na Figura 7, apresenta-se o tempo de retorno de cada ganho, calculado através da distribuição empírica, modelo quadrático e distribuição Gama. Para as variedades de ciclo normal, distribuição Gama, com parâmetro $\alpha$ de 1,094 e $\beta$ de 2670,21 , representa bem a distribuição empírica, com nível de significância de 0,100 segundo teste de Smirnov-Kolmogorov. O modelo quadrático desenvolvido com os ganhos com irrigação, permite um cálculo de maneira mais simplificada e com um coeficiente de correlação $\mathrm{R}^{2}$ de 0,996 , com a seguinte forma:

$\operatorname{Tr}=a+b G A N H O+c G A N H O^{2}$,

Sendo : $\mathrm{Tr}$ - o tempo de retorno em anos de determinado nível de ganho (anos);

GANHO - acréscimo de rendimento devido a irrigação $(\mathrm{kg} / \mathrm{ha})$;

a...c - coeficientes do modelo, $(a=1,182, b=-1,034$ E-04, $c=2,4035$ E-07).

Para um tempo de retorno de 2 anos, (probabilidade de $50 \%$ de ocorrer) o ganho esperado é de aproximadamente $2100 \mathrm{~kg} / \mathrm{ha}$. O máximo ganho de rendimento, esperado para um período de retorno de 28 anos, é de até $10765 \mathrm{~kg} / \mathrm{ha}$.

Entre as variedades de ciclo precoce, o comportamento foi diferente do verificado com as normais. Os ajustes dos modelos teóricos à distribuição empírica foram diferentes dos obtido com as de ciclo normal. Quanto à distribuição gama, parâmetro $\alpha$ $=1,323$ e $\beta=2731,63$, mostrou-se adequada para representar a distribuição empírica com significância de 0,100 , segundo o teste de Smirnov-Kolmogorov. O modelo cúbico ajustado apresentou coeficiente de correlação $R^{2}$ de 0,988 , com o seguinte formato: 
$T r=a+b G A N H O+c G A N H O^{2}+d G A N H O^{3}$

Sendo: $\mathrm{Tr}$ - tempo de retorno de determinado nivel de ganho (anos);

a...d - Coef. do modelo $(a=0,960, b=9,736 \mathrm{E}-4, \mathrm{c}=-3,682 \mathrm{E}-7, \mathrm{~d}=4,289 \mathrm{E}-11)$
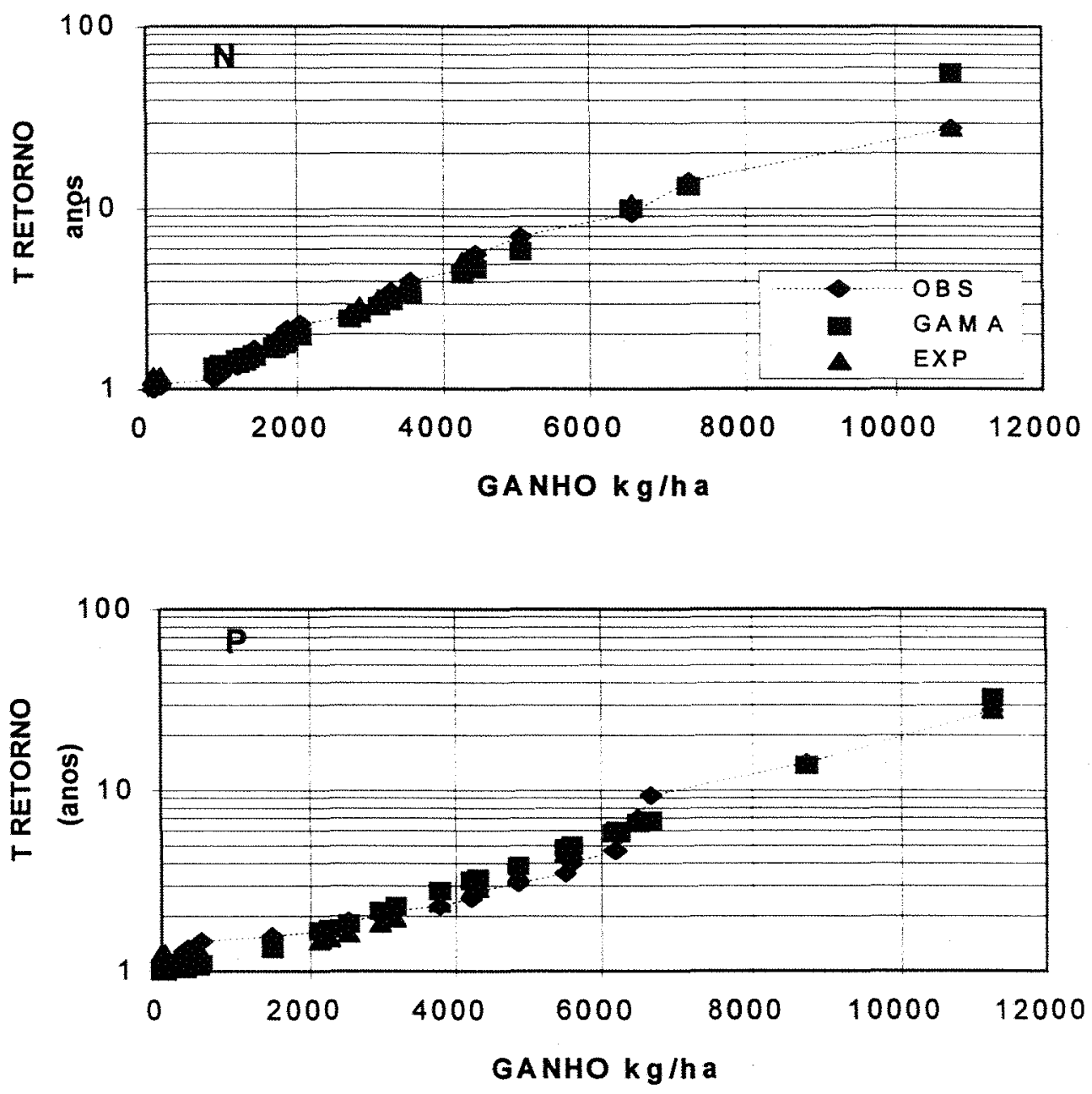

Figura 07 - Ganhos com irrigação simulados com o modelo completo e tempos de retorno com distribuição empírica (EMP), Gama (GAMA) e modelo exponencial (EXP), para variedades de ciclo normal (N) e precoce $(\mathrm{P})$. 
Conforme se pode observar no Quadro 18, os ganhos com irrigação estimados foram praticamente nulos em 5 anos, podendo-se esperar, então, que, em determinados anos, a irrigação não traga acréscimo de rendimento. Nestes anos, 1965, 1975, 1976, 1982, 1989 e 1992, os efeitos do excesso foram marcantes, anulando os efeitos da irrigação. Para um nível de probabilidade de $50 \%$, espera-se um ganho de $3350 \mathrm{~kg} / \mathrm{ha}$, sendo que o maior rendimento esperado no tempo de retorno de 28 anos é de 11271 $\mathrm{kg} / \mathrm{ha}$. 


\section{CONCLUSÕES}

1 - O modelo no qual considerou-se conjuntamente os efeitos do déficit e de excesso hídrico, pode ser empregado para estimativas de rendimento sob condições de cultivo irrigado e não irrigado.

2 - As possibilidades da irrigação estão limitadas pelos níveis de excesso hídrico que ocorrem no ciclo da cultura, havendo anos em que, mesmo apresentando déficits em alguns períodos, os acréscimos de rendimento são nulos.

3 - Para o período e a região estudados, obtém-se incremento de rendimentos com a irrigação, variáveis de acordo com as condições climáticas do ano agrícola, podendo assumir desde valores nulos até $11200 \mathrm{~kg} / \mathrm{ha}$, aproximadamente.

4 - A diminuição dos rendimentos provocado pelo excesso hídrico supera aquela provocada pelo déficit para variedades de ciclo normal. Para as de ciclo precoce, predominaram os efeitos provocados pelos déficits.

5 - Para tempos de retorno de 2, 3 e 5 anos, as expectativas de acréscimos de rendimento com irrigação, são de 2100, 3000 e $4250 \mathrm{~kg} /$ ha para variedades de ciclo normal, e 3350 , 4450 e $5800 \mathrm{~kg} / \mathrm{ha}$ para precoces. 


\section{REFERÊNCIAS BIBLIOGRÁFICAS}

AGUINSKI, S.D.; DORFMAN, R.; MATZENAUER, R. Modelos para prognóstico do rendimento do milho (Zea Mays, L.). In: CONGRESSO NACIONAL DE IRRIGAÇÃO E DREANAGEM, 8., Florianópolis, 1988. Anais. Florianópolis: Associação Brasileira de Irrigação e Drenagem, 1988. p.161-81.

AHMAD, N.; KANVAR, R.S. Effects of diferent moisture stress levels on corn growth in field lisimeters. Transactions of the ASAE, v. 34, p.1991-6,n. 5, Sep./Oct 1991.

ALTHOFF, D.A. Balanço hídrico seriado de Santa Catarina. Florianópolis: EMPASC, 1981. 62 p. (EMPASC. Boletim Técnico, 7)

ALTHOFF, D.A., SôNEGO, M.; POLA, A.C. Parâmetros para a agricultura irrigada de Santa Catarina: Evapotranspiração potencial. Florianópolis, EPAGRI, 1995. 48 p. (EPAGRI. Boletim Técnico) no prelo.

ARKLEY, R.J. Relationships between plant and transpiration. Hilgardia. v. 33, p.55984, Sept. 1963.

BARBIERI, V.; TUON, R.L. Metodologia para estimativa da produção potencial de algumas culturas. Piracicaba, 1992. $17 \mathrm{p}$.

BARRET, J.W.; SKOGERBOE, G.V. Effects of irrigation regime on maize yelds. Journal of the Irrigation and Drainage Division, v. 104, p. 179-94, June.1978.

BAYER, W. Note on the tterminilogy of crop-water models. Agricultural Meteorology, v. 20, n. 2, p. 137-45, mar/apr 1979.

BEGG, J.E.; TURNER, N.C. Crop water déficits. Advances in Agronomy, n. 28, p. 161-207, 1976.

BERLATO, M.; FONTANA, D.C.; GONÇCALVES, H. Relações entre o rendimento de grãos da soja e variáveis meteorológicas. Pesquisa Agropecuária Brasileira, v. 27, p. 695-702, maio 1992.

BERNARDO, S. Manual de irrigação. Viçosa: UFV, 1984. 463p. 
BOYER, J.S.; McPHERSON, H.G. Physiologiy of water déficits in cereal crops. Advances in Agronomy, v. 27, p. 1-23, 1975.

BRAGA, H.J. Caracterização da seca agronômica através de modelo de balanço hídrico, na Região de Laguna, litoral sul do Estado de Santa Catarina. Piraciacaba. 1982, 157p. Dissertação (Mestrado)-Escola Superior de Agricultura "Luiz de Queiróz", Universidade de São Paulo.

BRUNINI, O., MIRANDA, M.A.C., MASCARENHAS, H.A.A., PEREIRA, J.C.V.N.; CHIMIDT, N.C. Teste de um modelo agroclimático que relacione o regime luviomértrico com as variações da produtividade agrícola, In: Determinação do feito da precipitação pluviométrica na produção agrícola, Brasília, CFP, 1982. p.21-6 (Coleção Análise e Pesquisa, 24)

CAMARGO, M.B.P.; BRUNINI, O.; MIRANDA, M.A.C. Modelo agrometeorológico para estimativa da produtividade para a cultura da soja no estado de São Paulo. Bragantia, v. 45, n. 2, p. 279-92, jul. 1986.

CAMARGO, M.B.P.; MIRANDA, M.A.C.; PEDRO JUNIOR, M.J.; PEPEIRA, .C.V.N.A.; MASCARENHAS; H.A.A. Estimativa da produtividade potencial de cultivares de soja nas condições de RibeirãoPreto, S.P. Bragantia, v 47, n.7, p. 277. 88, jul. 1988.

CAMARGO, M.B.P Determination of the water balance components and drought ensivity índices for a sorghum crop. Lincoln, 1993.131 p. Thesis, (Phd) University of Nebraska.

CAMARGO, M.B.P; HUBBAD, K.G.; FLORES-MENDOZA,F. Test of a soil water assesment model for sorghum crop under diferent irrigation treatments. Bragantia, v. 53, p. 95-105, July. 1994.

CAMP. C.R.; SADLER, E.J.; SNEED, R.E.; HOOK, J.E.; LIGETIARI, F. Irrigation for humid areas. In: HOFFMANN, G.H.; HOWELL, T.A.; SOLOMON,H. ed. Management of farm irrigation systems, St. Joseph: ASAE, 1990.

CASSEL, D.K.; MARTIN, C.K.; LAMBERT, J.R. Corn irrigation scheduling in humid egions on sandy soils with tilage pans. Agronomy Journal, v. 77, p.851-5, Nov./Dec. 1985.

CHAUDARY, T.N.; BHATNAGAR, V.K.; PRIHAR, S.S. Corn yeld and nutrient uptake as afected by water-table and soil submergenge. Agronomy Journal, v. 67, p. 745-9, Nov./Dec. 1975. 
CLAASSEN, M.M.; SHAW, R.H. Water déficts effects on corn. II. Grain omponents. Agronomy Journal, v. 62, p. 652-5, Set./Oct. 1970.

COSTA, J.O.; FERREIRA, L.G.R.; SOUZA, F. Produção do milho submetido a diferentes níveis de stresse hídrico. Pesquisa Agropecuária Brasileira, v. 23, n. 11, p. 1255-61, nov. 1988.

CRAFTS, A.S. Water déficits and physiological processes. In: KOZLOWSKI, T.T.; ed., Water déficit and plant growth. N. York: Academic Press, 1982. v. 2.

DENMEAD, O.; SHAW, R.H. The effects of soil moisture stress at different stages of growth on the development and yeld of corn. Agronomy Journal, v.52, n. 5, p. 272-4, May, 1960.

DYER, J.A.; BAYER, W. An index for soil moisture drying paterns. Canadian Agricultural Engineering, v.21, n.2, p.117-8, Dec. 1979.

DOORENBOS, J.; KASSAN, A.H.. Efeito da água no rendimento das culturas, Campina Grande: Universidade Federal da Paraíba, 1994. 306 p. (Estudos FAO Irrigação e Drenagem, 33).

EASTIN, J.D. ; SULLIVAN, C. Y. Enviromental stress influences on plant persistence, hysiology, and production. In: EASTIN, J.D. ; SULLIVAN, C. Y., ed Physiological basis of crop growth and development. Madison: ASA, CSSA, 1981. p. 201-236.

ECK, H.V. Effects of water déficits on yeld., yeld components, and water use efficiency of irrigated corn. Agronomy Journal, v. 78, p. 1035-40, Nov./Dec. 1986.

EMPRESA BRASILEIRA DE PESQUISA AGROPECUÁRIA. Recomendações técnicas para a cultura do milho. Brasília: EMBRAPA/SPI,1993. 204p.

ESPINOZA, W. Resposta de 12 cultivares de milho ao déficit hídrico num latossolo vermelho-escuro (Typic Haplustox) de cerrados do Distrito Federal. Pesquisa Agropecuária Brasileira, v. 17, n. 6, p. 905-15, jun. 1982.

ESPINOZA, W; AZEVEDO, J. ROCHA, L.A. Densidade de plantio e irrigação suplementar na resposta de três variedades de milho ao déficit hídrico na região dos cerrados. Pesquisa Agropecuária Brasileira, v. 15, n. 1, p. 85-95, jan. 1980.

EVANS,R.O.; SKAGGS, R.W.; SNEED, R.E. Stress day index models to predict corn and soybean relative yeld under high water table conditions. Transactions of the ASAE, v. 34, n. 5, p. 1997-2005, Sept./Oct.1991. 
EVANS,R.O.; SKAGGS, R.W.; SNEED, R.E. Normalized crop suceptibility factors for corn and soybean to excess water stress. Transactions of the ASAE, v. 33, n. 4, p. 1153-61, July./Aug. 1990.

EMPRESA CATARINENSE DE PESQUISA AGROPECUÁRIA/EMPRESA DE ASSISTÊNCIA TÉCNICA E EXTENSÃO RURAL-SC/ACARESC Sistemas de produção para milho: (2 $\frac{a}{-}$ revisão). Florianópolis, 1993. 56p. (EMPASC/ACARESC.Sistemas de produção-4)

FANCELLI, A.L. Tecnologia da produção do milho para alta produtividade Piracicaba: Gráfica Universitária de Piracicaba, 1994. 223p.

FRIZZONI, J.A. Análise de cinco modelos para o cálculo da distribuição e frequência de precipitação na região de Viçosa, MG. Viçosa, 1979. 100p. Dissertação (Mestrado)- Universidade Federal de Viçosa.

HAAN, C.T. Statistical methods in hidrology. Ames: University Press, 1977.378 p.

HALL, W.A.; BUTCHER, W.S. Optimal timinq of irrigation. Journal of the Irrigation and Drainage Division, v. 94, p. 267-75, Jun 1968.

HANKS, R.J. Model for predictinq plant yeld as influenced by water Use. Agronomy Journal, v. 66, p. 660-5, Sept./Oct. 1974.

HANKS, R.J.; RASMUSSEN, V.P. Predictinq crop production as related to plant water stress. Advances in Agronomy, v. 35, p. 193 215, 1982.

HANWAY, J.J. Growth stages of corn (Zea mays, L). Agronomy Journal, v. 55, p 48792, Sept/Oct 1963.

HARDJOAMIDJOJO, S.; SKAGS, R.W.; SCHWAB, G.O. Corn yeld response to excessive soil water conditions. Transactions of the ASAE, v. 25, n. 4, p. 922-7, 934, July./Aug. 1982.

HILL, R. Irrigation scheduling. In: HANKS, J.; RITCHIE, J.T. ed. Modeling plant and soil systems. Madison: ASAE/CSSA/SSSA, 1991. cap. 21, p491-509.

HILER, E.A. Quantitative eavluation of crop-drainage requirements. Transactions of the ASAE, v. 12, n. 4, p. 499-505, July./Aug. 1969.

HILER, E.A.; HOWELL, T.A.; LEWIS, R.B.; BOOS, R.P. Irrigation timing by stress day index method. Transactions of the ASAE, v.17, n. 3, p. 393-8, May/June. 1974. 
HILLEL, D.; GURON, Y. Relation between evapotranspiration rate and maize yeld. Water Resources Research, v. 9, n. 3, p. 743-8, June 1973.

HOWELL, T.A.; HILLER, E.A.; ZOLEZZI, O.; RAVELO, C. Grain sorghum response to inundation at thre growth stages. Transactions of the ASAE, v.19, n. 4, p. 87680, July./Aug. 1976.

JENSEN, M.E. Water Consumption by agricultural plants In KOSLOWSKI, T.T., ed. Water déficits and plant growth. N.York: Academic Press, 1968. v.2, p.1-22.

JONES, P.N.; CAMBERRY, P.S. A tecnique to develop and validate simulation models. Agricultural Systems, v.46, n. 4, p.427-42, Sept. 1994.

KRAMER, P.J. Plant and soil water relationships New York: McGraw Hill, 1969. $482 \mathrm{p}$.

KRYSZIG, E. Advanced engineering mathematics. New York: John Wiley, 1993. 1271 .

LETEY, J.; STOLZI, L.H.; BLANK, G.B. Effects of duration and timing of low soil oxigen content on shoot and root growth. Agronomy Journal, v. 45, n. 1, p. 34-7, Jan./Feb. 1962.

LUITGARDS de MOURA, M.C.F. Determinação do consumo de água para acultura do milho (Zea mays, L.) pelo método lisimétrico. Piracicaba, 1982, 94p., Dissertação (Mestrado), Escola Superior de Agricultura "Luiz de Queiroz", Universidade de São Paulo.

MATZENAUER, R.; WESTPHALEN, S.L.;BERGAMASCHI, H. Estimativa do saldo de radiação sobre um a comunidade de milho (Zea Mays L.) a partir da radiação global In: CONGRESSO BRASILEIRO DE AGROMETEOROLOGIA, 2, Pelotas, 1981. Resumos ampliados. Pelotas: UFP, 1981. p.102-5.

MATZENAUER, R.; WESTPHALEN, S.L.;BERGAMASCHI, H. Relações entre a evapotranspiração do milho e as fórmulas de Penman e Thorthwaite. Pesquisa Agropecuária Brasileira, v. 18, n. 11, p. 1207-14, nov. 1983.

MATZENAUER, R.; FONTANA, D.C. Relação entre rendimento de grãos e altura de chuva em diferentes períodos de desenvolvimento do milho. In: CONGRESSO BRASILEIRO DE AGROMETEOROLOGIA, 5., Belém: 1987. Coletânea de Trabalhos. Belém: Sociedade Brasileira de Agrometeorologia, 1987. p. 3-6. 
MATZENAUER, R.; BERGAMASCHI, H. Relação entre o índice ETr/ETm e o rendimento de grãos de milho. In: CONGRESSO BRASILEIRO DE AGROMETEOROLOGIA, 3. Porto Alegre, 1993. Resumos. Porto Alegre: Sociedade Brasileira de Agrometeorologia,1993. p. 58.

MATZENAUER, R. Modelos agrometeorológicos para estimativa do rendimento de milho em função da disponibilidade hídrica no estado do Rio Grande do Sul. Porto Alegre. 1994. 172p. Tese (Doutorado) Universidade Federal do Rio Grande do Sul).

MEDEIROS, S.L.P.; WESTPHALEN, S.L.; MATZENAUER, R.; BERGAMASCHI, H. Relações entre evapotranspiraçào e rendimento de grãos de milho. Pesquisa Agropecária Brasileira, v. 26, n. 1, p. 1-10, jan. 1991.

MEYER, S.J.; HUBBARD, K.G.; WILHITE, D. A crop-specific droght index for corn: I. Model development and validation. Agronomy Journal, v. 86, p. :388-95, Mar./Apr. 1993.

MILLAR, A.A. Drenagem de terras agrícolas. São Paulo: McGraw-Hill, 1974. 267 p.

MUKHTAR, S.; BAKER, J.L.; KANVAR, R.S. Corn growth as affected by excess soil water. Transactions of the ASAE, v. 33, n.2, p. 437-42, Mar./Apr. 1990.

MUSICK, J.T.; DUSEC, D.A. Irrigated corn yeld responses to water. Transactions of the ASAE, v. 23, n. 1, p. 92-8, Jan./Feb. 1980.

NETER, J.; WASSERMAN, W.; KUTNER, M.H. Applied linear regression models. Homewod: Richard Irwin, 1983. 547p.

OMETTO, J.C. Bioclimatologia vegetal. São Paulo: Ceres, 1981. 440p.

PEDRO JÚNIOR, M.J., CAMARGO, M.B.P., BRUNINI, O., ALFONSI, P. R., ORTOLANI, A.A. E MIRANDA, M.A.C. Teste de um modelo para estimativa da produtividade da soja de ciclo precoce. In: CONGRESSO BRASILEIRO DE AGROMETEOROLOGIA, 3. Campinas, 1983. Anais, Campinas: Instituto Agronômico de Campinas, 1983. p. ll-7.

PEREIRA, A.R. Crop planning for diferent enviroments. Agricultural Meteorology, v. 27, p.71-7, Nov. 1982.

RADULOVICH, R. AQUA, a model to evaluate water déficits and excesses in tropical cropping. Part I. Basics assunptions and yeld. Agricultural and Forest Meteorology, v. 40, n. 4, p. 305-21, Sept. 1987. 
RADULOVICH, R. AQUA, a model to evaluate water déficits and excesses in tropical cropping. Part II. Regional yeld prediction. Agricultural and Forest Meteorlogy, v. 52, n. 3/4, p. 253-61, Sept. 1990.

RETTA, A.; HANKS, R.J. Corn and alfafa production as influenced by limited irrigation. Irrigation Science, v. 1, p. 135- 47, Feb. 1980.

RHOADS, F.M.; BENNET, J.M. Corn. In: STEWART, B.A. NIELSEN, D.R.ed. Irrigation of agricultural lands. Madison: ASA/CSSA/SSSA, 1990. p. 569-96. (Agronomy, 30).

RITTER, W.F.; BEER, C.E. Yeld reduction by controled flooding of corn. Transaction of the ASAE, v.12, n. 1, p. 46-7,50, 1969.

ROBINS, J.S.; DOMINGO, C.E. Some effects of severe soil moisture at specific growth stages in corn. Agronomy Journal, v. 45, n. 12, p. 618-21, Dec. 1953.

ROBINSON, J.M.; HUBBARD, K.G. Soil water assesment model for several crops in the high plains. Agronomy Journal, v. 82, p. 1141-8, Nov./Dec. 1990.

SAAD, J.C.C. Estudo das distribuições de frequência da evapotranspiração de referência e da precipitação pluvial para fins de dimensionamento de sistemas de irrigação. Piracicaba, 1990. 124p. Dissertação (Mestrado) Escola Superior de Agricultura "Luiz de Queirós", Universidade de São Paulo.

SAMANI, Z.A.; HARGREAVES, H. A crop water evaluation manual for Brazil. Logan: Utah State University, 1985. 87p.

SANTA CATARINA, Secretaria Da Agricultura, Levantamento semi-detalhado dos solos das regiões de Laguna e sul do Estado de Santa Catarina, Santa Maria: Imprensa Universitária, 1973.

SEGOVIA, R.M.; ANDRADE, E.G. Um modelo de determinação do efeito da precipitação pluviométrica na produtividade agrícola. In: Determinação do efeito da precipitação pluviométrica na produção agrícola. Coleção Análise e Pesquisa, CFP, n. 24, p.11-18, ago. 1982

SERRANO, L.; CARBONEL, X.; SAVÉ, R.; MARFÁ, O.; PENELAS, J. Effects of irrigation regimes on the yeld and water use of strawberry. Irrigation Science. v. 13, p. 45-8, mar. 1992.

SINGH, R.; GUILDYAL, B.P. Soil submergence effects on nutrient uptake, growth. and yeld of five corn cultivars. Agronomy Journal, , v. 72, n. 5, p. 737-41, Sept./Oct. 1980. 
SLATIER, R.O. Plant-water relationships. Camberra, Academic Press: 1967. 266p.

STEGMAN, E.C., SCHATZ, B.G.; GARDNER, J.C. Yeld sensivities of short season soybeans to irrigation manaqement. Irrigation Science, v. 11, p. 111-9, Apr. 1990.

STEWART, B.A.; NIELSEN, D.R. The task of irrigation development. In: STEWART, B.A.; NIELSEN, D.R. ed. Irrigation of agricultural lands. Madison: ASA, CSSA, SSSA, 1990. p 1-30. (Agronomy, 30).

STEWART, J.I.; MISRA, R.D.; PRUIT, W.O.; HAGAN, R.M. Irrigating corn and sorghum with a deficient water supply. Transactions of the ASAE, v. 18, p. 27080, $\mathrm{m}$ ?? 1975.

THOM, H.G.S. Note on the Gama distribuition. Monthly Review, v. 86, n. 4, p. 11722, 1958.

THORNTHWAITE , C.W.; MATHER, J.R. The water balance. Publications in Climatology, v. 8, n. 1, 104 p, 1955.

VAUX, H.,J.; PRUTTT, W.O. Crop-water productions functions. Advances In Irrigation, v2, p. 61-97, 1983.

VILEGAS de los R., E.; CORREA, J.J.A.; MUNOS, S. Tolerância de genótipos de maiz (Zea mays L.) a sequia en el Cerrito, Valle. Acta Agronômica, v. 35, n. 1, p. 7-22, Jan 1985.

WENDA, W.I.; HANKS, R.,J. Corn yeld and evapotranspiration under simulated droght conditions. Irrigation Science, v. 2, n. 4, p. 193-204, Nov. 1981.

WESSELING, J. Crop growth and wet soils. In: SCHIFGAARDE, J. van, ed.. Drainage for agriculture. Madison: American Society of Agronomy, 1974. p. 137. (ASA 17)

WILLMOT, C.J. On the validation of models. Physical Geography, v. 2, n. 2, p. 18494, 1981.

WOUDT, B. van't ; HAGAN, R.M. Land drainage em relation to soils and crops. In: LUTHIN, J.N., ed. Drainage of agricultural lands. Madison: American Society of Agronomy, 1957. p. 461-578. (ASAj 7) 